Универзитет у Београду

Медицински фракултет

Душко В. Спасовски

\title{
Биомеханичка анализа
}

\section{троструке остеотомије карлице}

Докторска дисертација

Београд, 2012 
University of Belgrade

School of Medicine

Duško V. Spasovski

\section{Biomechanical analysis \\ of triple pelvic osteotomy}

Doctoral dissertation

Belgrade, 2012 
Ментор:

Проф. др Зоран Вукашиновић, редовни професор Медицинског факултета Универзитета у Београду

Чланови комисије:

1. Проф. др Горан Чобељић, редовни професор Медицинског факултета Универзитета у Београду

2. Проф. др Јелена Маринковић-Ерић, редовни професор Медицинског факултета Универзитета у Београду

3. Проф. др Слободан Славковић, редовни професор Медицинског факултета Универзитета у Београду (није у радном односу на Факултету)

Датум одбране: 
Овај миљоказ на животном путу посвећујем мојој породици, захвалан за родитељску бригу, супруге подршку, деце разумевање.

Посебно сам захвалан ментору, за оштро око, благу реч и бритку мисао. 


\section{БИОМЕХАНИЧКА АНАЛИЗА ТРОСТРУКЕ ОСТЕОТОМИЈЕ КАРЛИЦЕ}

\section{Резиме}

Увод. Неподударност зглобних површина у зглобу кука карактеристика је многих болести дечјег и адолесцентског доба, и услед поремећене равнотеже сила које делују на зглобну хрскавицу, превазилазећи њен адаптивни капацитет, неизбежно води у дегенерацију зглоба и рани инвалидитет. Доминантна метода оперативног лечења овог поремећаја у адолесцентском узрасту у нашој средини је Тенисова техника троструке остеотомије карлице. Ефекти примене ове и других оперативних метода на зглоб кука су објективно мерљиви применом различитих нумеричких и аналитичких математичких модела зглоба кука. Најчешћи математички модел зглоба кука који се користи у биомеханичким функционалним анализама зглоба кука је тродимензионални модел базиран на нативној радиографији. Он је у последњих 15 година широко примењиван на здраве зглобове, као и на зглобове кука оперисане разним методама. До сада није примењиван на Тенисову троструку остеотомију карлице.

Циљеви рада. Применом тродимензионалног математичког модела на радиограм карлице са куковима у антеропостериорној (АП) пројекцији пре и после троструке остеотомије карлице, прорачунати биомеханичке елементе силе притиска у зглобу кука (правац, нападни угао и интензитет резултантне силе притиска, градијент дистрибуције по зглобним површинама) и анализирати однос поменутих величина према мерљивим клиничким и радиографским параметрима.

Материјал и метод. Од 92 случаја поремећене подударности зглоба кука код пацијената адолесцентског узраста (услед развојног поремећаја кука, постредукционе аваскуларне некрозе главе бутне кости или Лег-КалвеПертесове болести), који су оперисани троструком остеотомијом карлице у Институту за ортопедско-хируршке болести "Бањица" у Београду од 1996. до 2011. године, у испитивану групу је укључено 75 кукова код 60 пацијената, са просечним Виберговим ЦЕ углом од 15,18+/-9,31․ Поред испитиваних кукова, на радиографијама су мерени и њима наспрамни кукови, од којих су формиране две контролне групе: негативна (здрави кукови - 19 случајева), и позитивна (промењени кукови - 56 случајева). На све случајеве је примењен 
тродимензионални математички модел зглоба кука базиран на нативној радиографији карлице са куковима у АП пројекцији аутора Иглича и сар. (1990), и то преоперативно, постоперативно и као завршни налаз, у циљу квантификације биомеханичког ефекта примене троструке остеотомије карлице. Прикупљени клинички и биомеханички подаци описани су стандардним дескриптивним статистичким методама, и анализирани одговарајућим методама статистичке анализе.

Резултати и дискусија. Након операције установљено је повећање ЦЕ угла до нормалних вредности (медијана $33,45^{0}$ ), смањење угла максималног притиска ( $\Theta$-pol) за 63,5\% (са $43,44^{0}$ на $15,85^{0}, \mathrm{p}<0,01$ ), максималне силе притиска, и то апсолутне (Pmax) за 46,2\% (са 1,69 MPa на 0,91 MPa, p<0,01) као и нормализоване на телесну тежину (Pmax/Wb) за 55,9\% (са 4026,49 на 1776,75). Индекс градијента притиска $(\mathrm{Gp} / \mathrm{Wb})$ је такође постоперативно смањен са 4,67 на $-0,48,(p<0,01)$ достижући вредности прорачунате у негативној контролној групи (опсег од $-4,77$ до 1,05 , медијана -1,02). Као предиктори функционалног и анатомског исхода на крају постоперативног праћења које је трајало 3,48+/-2,77 година, издвојили су се преоперативни параметри ЦЕ угао $(p<0,01)$ и квалитет хода $(\mathrm{p}<0,05)$. Близу границе статистичке значајности су били преоперативни параметри полупречник ротације у зглобу кука $(\mathrm{p}=0,052)$, нормализована резултантна сила $(\mathrm{p}=0,053)$, као и постоперативни индекс градијента притиска $(\mathrm{p}=0,059)$. Биомеханички модел је потврђен као валидан за анализирање клиничког материјала, начин мерења је генерисао толерантну систематску грешку (мању од 4,1\%), а добијене вредности су углавном у складу са налазима других истраживача.

Закључак. Тенисова трострука остеотомија поуздано и ефикасно побољшава дистрибуцију силе притиска на ацетабуларну хрскавицу, и тиме обезбеђује добар исход лечења поремећаја подударности зглоба кука код адолесцената. Примена тродимензионалног математичког модела зглоба кука омогућава прорачун важних биомеханичких параметара који описују механичко оптерећење хрскавице и имају предиктивну вредност за исход лечења, а нормализација према телесној тежини омогућава упоређење пацијената различите конституције. За прецизно мерење дуготрајних ефеката и оперативног лечења троструком остеотомијом карлице и примене математичког 
моделовања у његовој евалуацији, неопходно је већу групу оперисаних болесника пратити дуже, током одраслог доба.

Кључне речи: трострука остеотомија карлице, биомеханичка анализа, адолесценција, дисплазија ацетабулума, коксартроза, математички модел зглоба кука, контактни притисак, индекс градијента притиска, предиктор исхода. 


\title{
BIOMECHANICAL ANALYSIS OF TRIPLE PELVIC OSTEOTOMY
}

\begin{abstract}
$\underline{\text { Abstract }}$
Introduction. Hip joint incongruence is found in a number of hip joint disorders in childhood and adolescence. Altered hip joint compression force overcomes the adaptive capacity of joint cartilage, inevitably leading to degenerative joint changes and early invalidity.

Most utilized method for operative treatment of this impairment that we use in adolescent age is Tennis triple pelvic osteotomy. The effects of operative treatment can be objectively analyzed by numeric and analytic hip joint mathematical models. The mathematical model most used in hip joint biomechanical functional analysis is three-dimensional radiography-based model. It has been widely applied to normal hips and hips operated by various methods. However, it has not been applied to Tennis triple pelvic osteotomy.

Goals. To apply three-dimensional radiography-based mathematical model of the hip joint to standard anterioposterior pelvis and hip radiography, before and after triple pelvic osteotomy, to calculate parameters of contact hip stress distribution (direction, angle and intensity of resultant hip force, angle and magnitude of peak contact hip stress, the index of the hip stress gradient), and to analyze the relationship of biomechanical parameters to patients' standard clinical and radiographic data.

Material and method. Out of 92 patients with hip joint incongruence in adolescent age (due to developmental disease of the hip, postreductional avascular necrosis of femoral head or Leg-Calvé-Perthes disease), operated by Tönnis triple pelvic osteotomy at the Institute for Orthopaedic Surgery "Banjica" in Belgrade in the period from 1996. to 2011, 75 hips (60 patients) were included in the test group, with average Wiberg CE angle of $15,18+/-9,31^{0}$. All contralateral hips were also analyzed, and then divided in negative control group (healthy hips, 19 cases) and positive control group (deformed hips, 56 cases). The three-dimensional radiography-based mathematical model of the hip joint described by Iglič et al. (1990) was applied to all the hips, at preoperative, postoperative and final examination. All collected data were described by standard descriptive statistical tools, and analyzed by appropriate statistical tests.
\end{abstract}


Results and discussion. At postoperative measurements we found that $\mathrm{CE}$ angle increased reaching normal values (median 33.45\%), angle of peak hip pressure pole $\left(\Theta-\right.$ pol) was lower for $63.5 \%$ (from $43.44^{0}$ to $15.85^{\circ}, \mathrm{p}<0,01$ ), absolute peak hip pressure (Pmax) was lower for $46.2 \%$ (from 1,69 $\mathrm{MPa}$ to $0,91 \mathrm{MPa}, \mathrm{p}<0,01$ ) and peak hip pressure normalized to the body weight $(\mathrm{Pmax} / \mathrm{Wb}$ ) lower for $55.9 \%$ (from 4026.49 to 1776.75$)$. The index of the hip stress gradient $(\mathrm{Gp} / \mathrm{Wb})$ was also lower after surgery, from 4.67 to $-0.48(\mathrm{p}<0.01)$, reaching levels found in healthy controls (range from -4.77 to 1.05 , median -1.02 ). With follow up of $3.48+/-2.77$ years, we found two functional and anatomic outcome predictors: preoperative CE angle $(p<0.01)$ and preoperative gait quality $(p<0.05)$, and three more that are close to statistical significance level: preoperative hip joint rotation radius $(p=0.052)$, preoperative normalized hip joint force $(\mathrm{R} / \mathrm{Wb}, \mathrm{p}=0.053)$, and postoperative index of hip stress gradient $(\mathrm{Gp} / \mathrm{Wb}, \mathrm{p}=0.059)$. Biomechanical model proved to be reliable for analysis of clinical material, data collecting from radiograms generated very low systematical error (less than 4,1\%), and our results are generally in agreement with findings of others.

Conclusion. Tonnis triple pelvic osteotomy reliably and effectively improves hip joint stress distribution, leading to good result in the treatment of hip joint incongruence in adolescent age. The use of three-dimensional mathematical model of the hip enables the calculation of important biomechanical data that describe the mechanical cartilage load, and have an outcome predictive value, with normalization to body weight enabling the comparison of patients with different body shapes. Accurate measurement of long-term impact of triple pelvic astronomy, and the utilization of mathematical modeling, require larger group of patients followed up for loner period, throughout adult age.

Key words: triple pelvic osteotomy, biomechanical analysis, adolescence, acetabular dysplasia, osteoarthritis, mathematical hip joint modeling, hip joint contact stress, index of hip stress gradient, outcome predictor. 


\section{УВОД}

У многим болестима дечјег и адолесцентног доба може се констатовати неподударност зглобних површина у зглобу кука, узрокована било недовољном покривеношћу нормалне главе бутне кости диспластичним ацетабулумом, било немогућношћу покривања патолошки измењене главе бутне кости добро развијеним ацетабулумом, и услед поремећене равнотеже сила које делују на зглобну хрскавицу, превазилазећи њен адаптивни капацитет, еволуција таквих зглобова најчешће води у дегенерацију зглобне хрскавице и рани инвалидитет.

Адекватна и правовремена дијагностика и прецизно, биолошки правилно индиковано лечење наведених поремећаја зглоба кука у периоду адолесценције представља прави изазов за сваког ортопеда. За разумевање околности које утичу на патофизиолошки процес интеракције зглобних елемената није довољно само познавати анатомску грађу зглоба кука, већ и карактеристике процеса његовог морфолошког развоја, биомеханичке законитости које утичу на распоред и дејство механичких сила које делују на делове зглоба, те параметре њихове измене и побољшања које остварујемо применом различитих видова оперативног лечења. Само на тај начин могуће је систематски деловати на измени патофизиолошких услова у правцу њиховог претварања у физиолошке, обезбеђујући на тај начин да оболели или оштећени зглоб кука има што дужи период трајања и испуњавања своје физиолошке улоге: покрет, ослонац и ход.

\section{Анатомска грађа зглоба кука}

Зглоб кука (art. coxae) представља кугласти зглоб између карличне и бутне кости.

\section{КОСТИ ЗГЛОБА КУКА}

Карлична кост (os coxae) је велика парна пљосната кост која гради предњи и бочни зид карлице. Она настаје срашћењем три засебне кости: бедрене (os ilium), седалне (os ischii) и препонске (os pubis), и свака од њих има тело и један или више наставака. Тела те три кости се спајају у пределу зглобне чашице карличне кости (acetabulum) и њихово потпуно срашћење наступа око шеснаесте године 


\section{САДРЖАЈ}

УВОД

Анатомска грађа зглоба кука

Кости зглоба кука

Зглобне површине зглоба кука

Зглобне везе зглоба кука

Покрети у зглобу кука 28

Флексија у зглобу кука 8

Екстензија у зглобу кука 10

Абдукција у зглобу кука 11

Адукција у зглобу кука 11

Спољашња ротација у зглобу кука 12

Унутрашња ротација у зглобу кука 13

Развој зглоба кука 13

Поремећаји конфигурације зглоба кука у периоду адолесценције 15

Дијагностика 16

$\begin{array}{ll}\text { Лечење } & 18\end{array}$

Тенисова трострука остеотомија карлице 22

Оперативна техника 22

Биомеханика зглоба кука 23

Врсте и развој метода испитивања 23

Биомеханичке особије зглоба кука 25

Тродимензионални математички модел зглоба кука 29

ЦИљЕВИ ИСТРАЖИВАЬА 32

МАТЕРИЈАЛ И МЕТОДЕ 33

Испитивана група 35

Контролне групе 35

Метод истраживања 36 
$\begin{array}{ll}\text { РЕЗУЛТАТИ } & 40\end{array}$

Испитивана група 40

Мерење 1 (преоперативно) $\quad 40$

Мерење 2 (постоперативно) 43

Мерење 3 (завршно)

Поређење мерења 1 и 3

Контролне групе 47

$\begin{array}{ll}\text { Мерење } 1 & 47\end{array}$

$\begin{array}{lr}\text { Мерење } 2 & 48\end{array}$

Поређење испитиване и контролне групе 49

$\begin{array}{ll}\text { Мерење } 1 & 49\end{array}$

Предиктори оперативног резултата 49

ДИСКУСИЈА 51

Квалитет мерених и прорачунатих података 51

Поузданост

Валидност $\quad 53$

Дискриминативност

Прецизност

Биомеханички параметри зглоба кука 58

Максимални притисак на артикуларне површине (Pmax) 58

Резултантна сила у зглобу кука $\quad 58$

Нормализовани индекс градијента притиска $(\mathrm{Gp} / \mathrm{Wb})$

Биомеханички ефекат троструке остеотомије карлице 60

Предиктивни фактори резултата лечења 62

ЗАКљУЧАК 64

$\begin{array}{ll}\text { ЛИТЕРАТУРА } & 66\end{array}$ 


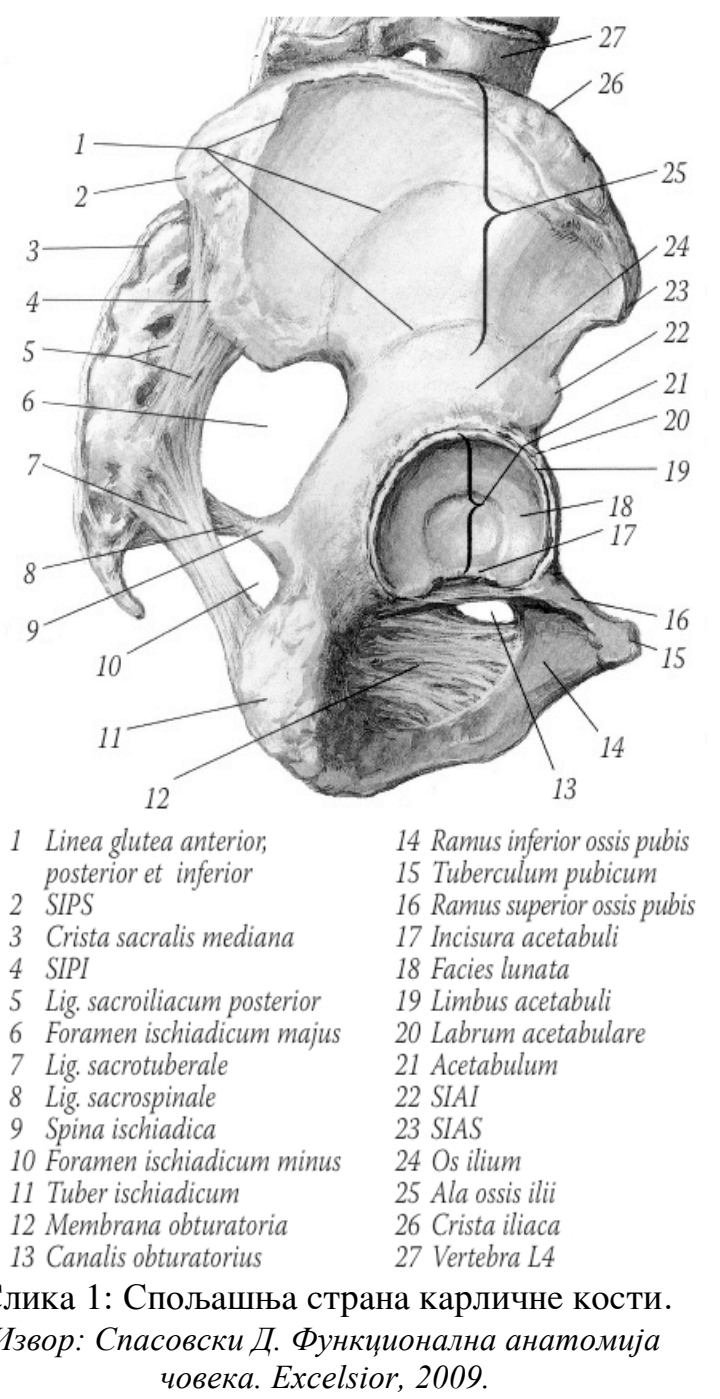

Облик карличне кости подсећа на крак бродског пропелера. Описују joj се две стране (унутрашња и спољашња), четири ивице (предња, задња, горња и доња) и четири угла.

Доминантан елемент на спољашњој страни је зглобна чашица (acetabulum), округласто удубљење са којим се зглобљава глава бутне кости (caput femoris), чинећи зглоб кука (art. coxae). У ацетабулуму се налази зглобна површина у облику непотпуног прстена, или полумесеца (facies lunata). Место прекидања прстена зглобне површине, у доњем делу ацетабулума назива се ацетабуларни усек (incisura acetabuli). Централни део ацетабулума је незглобно удубљење које се зове јама ацетабулума (fossa acetabuli), испуњена масним ткивом (pulvinar acetabuli), кроз које се пробија лигамент који спаја ацетабулум и главу бутне кости и назива се обла веза зглоба кука (lig. capitis femoris). Обод ацетабулума је бедемасто издигнут и зове ce limbus acetabuli, док је гребен непосредно изнад ацетабулума назван ацетабуларна надстрешица (supercilium acetabuli) и место је припоја одбојне тетиве правог мишића бута (m. rectus femoris).

Горњи део ацетабулума гради тело бедрене кости (corpus ossis ilium). Велики пљоснати део карличне кости изнад ацетабулума је крило бедрене кости (ala ossis ilii), чија је спољашња седална страна (facies glutea) двема лучним линијама које се зову предња и задња седална линија (linea glutea anterior et posterior) подељена на три поља: предње, средње и задње, где се редом припајају мали, средњи и велики седални мишић (m. gluteus minumus, $m$. gluteus medius et m. gluteus 
maximus). Непосредно изнад ацетабулума често постоји изражена и доња седална линија (linea glutea inferior).

Предње-доњи део ацетабулума чини тело препонске кости, а део карличне кости испред ацетабулума (према споју са супротном карличном кости) чини горња грана пубичне кости (ramus superior ossis pubis). Спој леве и десне карличне кости назива се пубична симфиза (symphysis pubica) и представља полупокретну везу. На горњој ивици горње гране налази се чешљасти гребен (pecten ossis pubis), који је наставак лучне линије (linea arcuata) смештене на унутрашњој површини карличне кости. Медијално се чешљасти гребен завршава препонском квргом (tuberculum pubicum). Читавом дужином чешљастог гребена припаја се Куперова препонска веза (lig. pubicum Cooperi), а на његовом унутрашњем крају и Гимбернатова веза (lig. lacunare Gimbernati).

На свом медијалном крају, у пределу симфизе, горња грана пубичне кости под оштрим углом прелази у доњу грану управљена пут назад, наниже и упоље до споја са граном седалне кости. Отвор који ограничавају гране препонске кости и

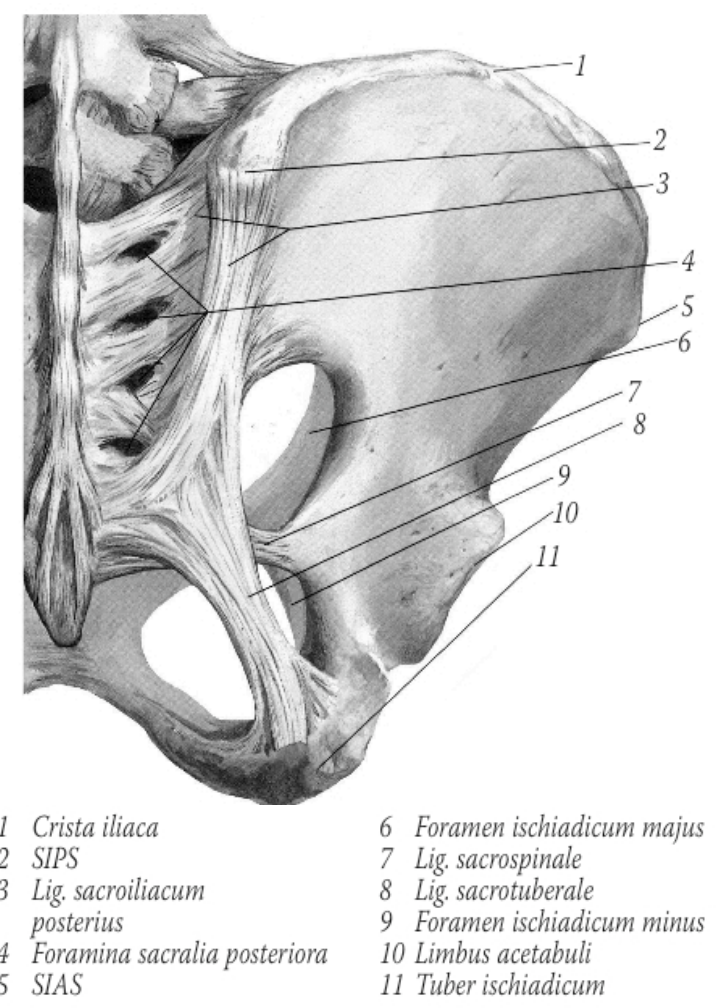

Слика 2: задња страна карличне кости. Извор: Спасовски Д. Функиионална анатомија човека. Excelsior, 2009. грана седалне кости назива се запорни отвор (foramen obturatum). Преко њега је разапета запорна опна (membrana obturatoria). На доњој страни горње гране пубичне кости постоји запорни жлеб (sulcus obturatorius).

Задње-доњи део карличне кости представља седална кост. Она има тело и једну грану. Тело је постављено скоро вертикално тако да његов горњи крај гради задње-доњи део ацетабулума а доњи крај тела гради седалну квргу (tuber ischiadicum). Ca врха седалне кврге се пут навише, унутра и унапред пружа грана седалне кости (ramus ossis ischii) у сусрет доњој грани пубичне кости, са којом је срасла. 


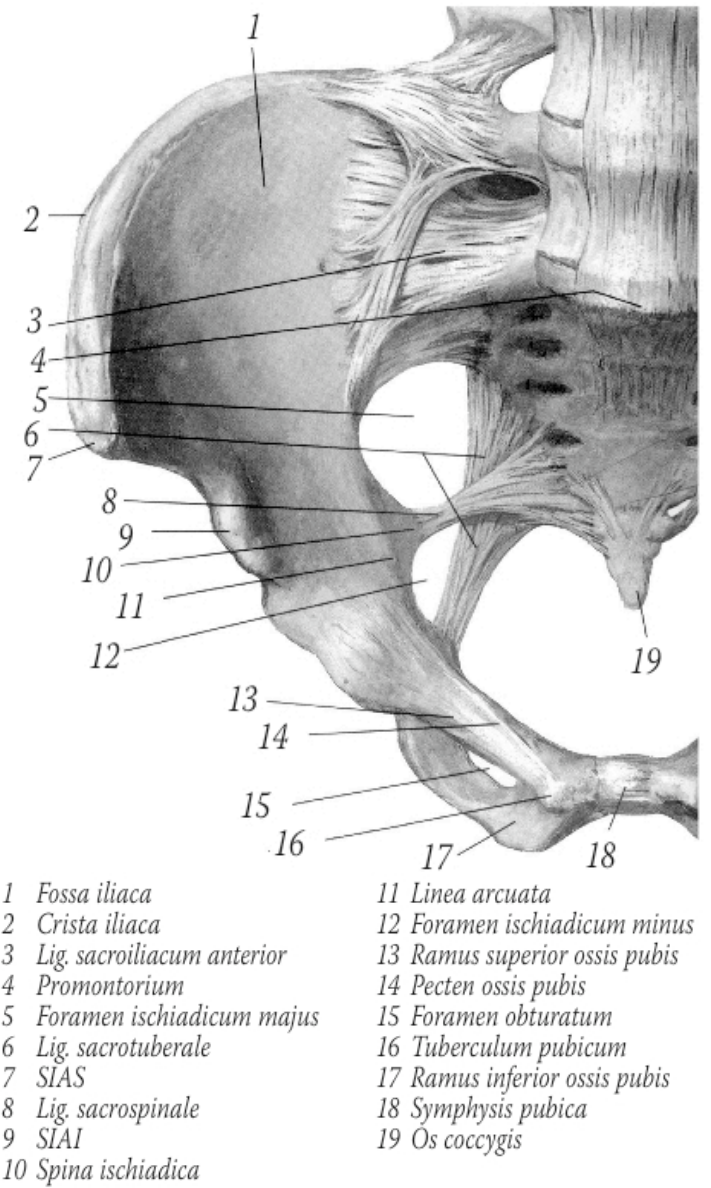

Слика 3: предња страна карличне кости Извор: Спасовски Д. Функиионална анатомија човека. Excelsior, 2009.
Унутрашња страна карличне кости је подељена лучним гребеном (linea arcuata) на горњи, трбушни део (pars abdominalis ossis coxae) и доњи, карлични део (pars pelvina ossis coxae).

Абдоминални део је већи од карличног, и чини га унутрашња страна бедрене кости. На њеном задњем делу налази се уваста зглобна површина (facies auricularis) за зглобљавање са крсном кости. Изнад ње је бедрено испупчење (tuberositas iliaca). Преостали део абдоминалног дела је у виду плитке бедрене јаме (fossa iliaca).

Карлични део се у задњем делу састоји из коштане површине која одговара дну ацетабулума, а напред га чини foramen obturatum оивичен двема гранама пубичне кости и граном седалне кости, и затворен оптураторном мембраном.

Предња ивица карличне кости је у целини и неједнако лучно удубљена, али поседује и извесна испупчења на којима се припајају мишићи, лигаменти и фасције. Задња ивица карличне кости је јаче изудубљена од предње. Горња ивица карличне кости је представљена лучно испупченим бедреним гребеном (crista iliaca) који се протеже од SIAS до SIPS. Бедрени гребен је широк, тако да разликујемо унутрашњу и спољашњу усну. На њему се припаја више мишића и лигамената. Доња ивица карличне кости се простире од symphysis pubica дуж доње гране пубичне кости и гране седалне кости, до tuber ischiadicum. 
Бутна кост (femur) је парна дуга цеваста кост, највећа и најјача кост човечијег тела ${ }^{1,2,3}$. Разликујемо тело и два окрајка.

Тело је тространо-призматично, те има следеће три стране (предњу, спољашњу и унутрашњу) и три ивице (спољашњу, унутрашњу и задњу). На предњој и спољашњој страни припајају се мишићи бута, док на унутрашњој страни нема припоја.

Од наведене три ивице спољашња и унутрашња су врло слабо изражене, док је задња ивица широка и испупчена, те се назива храпава линија (linea aspera). Разликујемо јој спољашњу усну, унутрашњу усну и међупростор, и сви они служе као места припоја одговарајућих мишића бута.

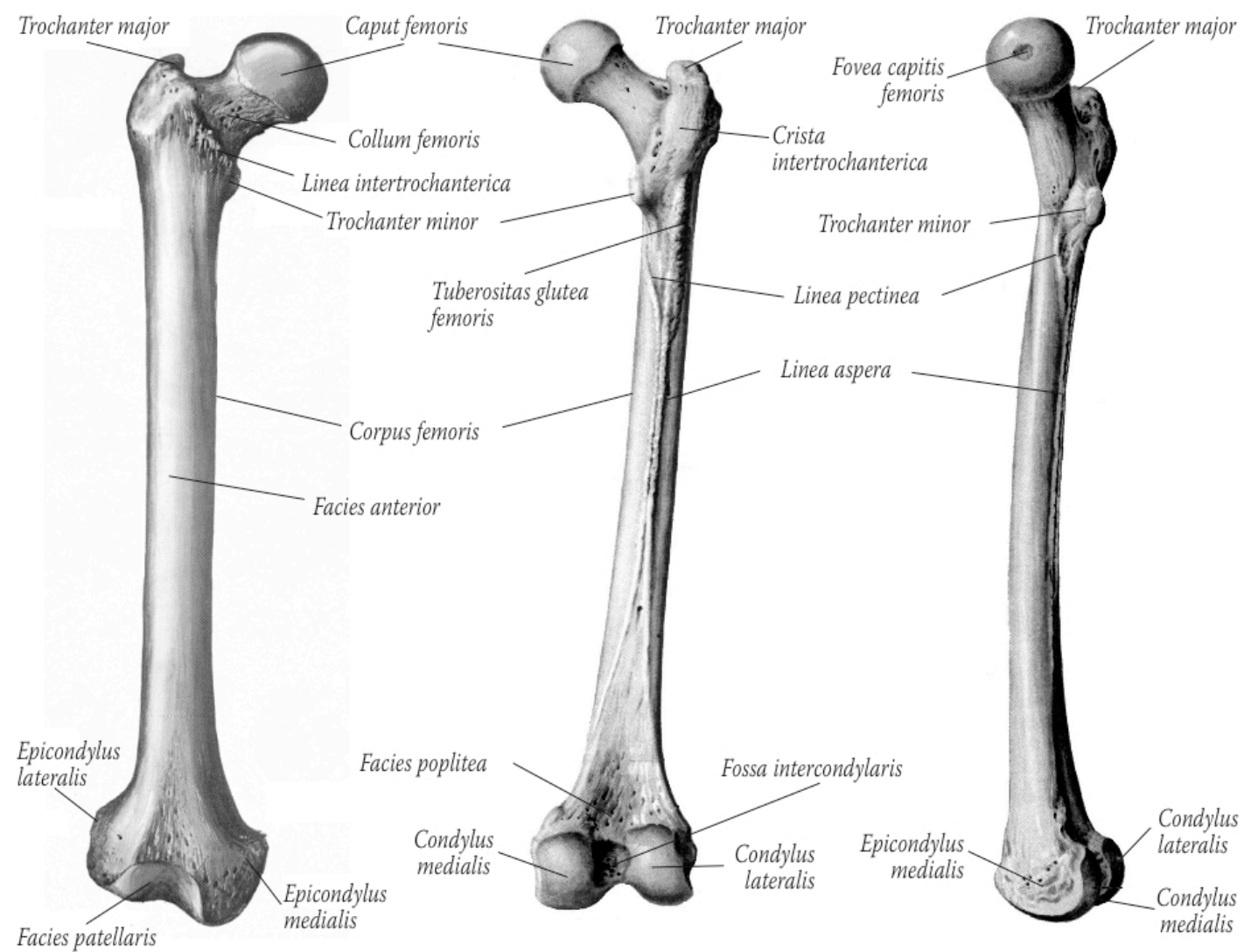

Слика 4: бутна кост

Извор: Спасовски Д. Функционална анатомија човека. Excelsior, 2009.

У доњем делу фемура усне се шире у виду две гране, заклапајући међу собом троугласту затколену површину (facies poplitea). На унутрашњој грани постоји квржица великог приводиоца (tuberculum adductorium) где се припаја истоимени мишић. На горњем крају усне се такође шире, али на три гране, односно појављује се и средња грана. Спољашња грана иде пут великог 
трохантера и зове се седални гребен бутне кости (tuberositas glutea femoris). Средња грана иде пут малог трохантера и зове се чешљаста линија (linea pectinea). Унутрашња грана иде испод малог трохантера.

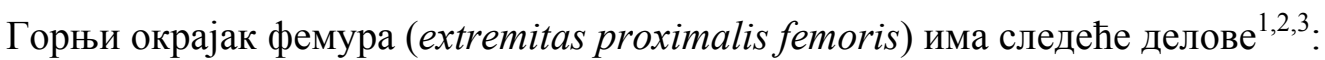

- Глава фемура (caput femoris) приближно лоптастог облика (око 2/3 површине лопте). На њој се налази јамица (fovea capitis femoris) где се припаја обла веза зглоба кука (lig. capitis femoris) која полази из fossa acetabuli.

- Врат фемура (collum femoris) стоји под углом од око 125 степени у односу на осовину тела фемура, управљен је пут наниже, упоље и уназад. Спљоштен од спреда пут позади.

- На споју врата и тела фемура запажају се спољашње испупчење звано велики трохантер (trochanter major) и унутрашње испупчење звано мали трохантер (trochanter minor). Између два трохантера се са предње стране простире међутрохантерна линија (linea intertrochanterica), а са задње стране јаче изражен међутрохантерни гребен (crista intertrochanterica).

- У Уутрашња страна великог трохантера, која стоји наспрам врата фемура, удубљена је и зове се трохантерична јама (fossa trochanterica). Два трохантера, интертрохантерна линија и гребен представљају венац на споју врата и тела фемура. Зглобна капсула зглоба кука припаја се дуж базе врата фемура, остављајући сва поменута испупчења ван зглоба, тако да се на њима припајају многобројни мишићи и лигаменти.

Доњи окрајак фемура (extremitas distalis femoris) се састоји из два велика зглобна испупчења, на пресеку полукружног облика. То су спољашњи и унутрашњи кондил (condylus lateralis et medialis femoris), који учествују у формирању зглоба колена.

У пределу унутрашње стране дисталног окрајка фемура постоји квржица великог примицача бута (tuberculum adductorium), а са спољашње стране налази се затколени жлеб (sulcus popliteus) за припој истоименог мишића. 


\section{ЗГЛОБНЕ ПОВРШИНЕ ЗГЛОБА КУКА}

Полумесечаста зглобна површина ацетабулума (facies lunata) се зглобљава са главом бутне кости (caput femoris). Ацетабулум је по ободу проширен и проудубљен хрскавичавим прстенастим гребеном, ацетабуларном усном (labrum acetabulare $)^{1,2,3}$.

\section{ЗГЛОБНЕ ВЕЗЕ ЗГЛОБА КУКА}

Спољашњи лист зглобне чауре појачава неколико веза. Са сваке од три кости које чине карличну кост (os ilium, os ischii, os pubis) полази по један лигамент ка интертрохантерној линији фемура (linea intertrochanterica femoris). Tо су бедренобутна веза, која се зове Бертинијев лигамент (lig. iliofemorale Bertini), и седалнобутна веза (lig. ischiofemorale), и препонскобутна веза (lig. pubofemorale).

Дубоки слој зглобне чауре састављен је из прстенасто постављених влакана, и то се означава као прстенаста веза (zona orbicularis). Она обухвата главу и врат фемура спречавајући испадање главе из ацетабулума.

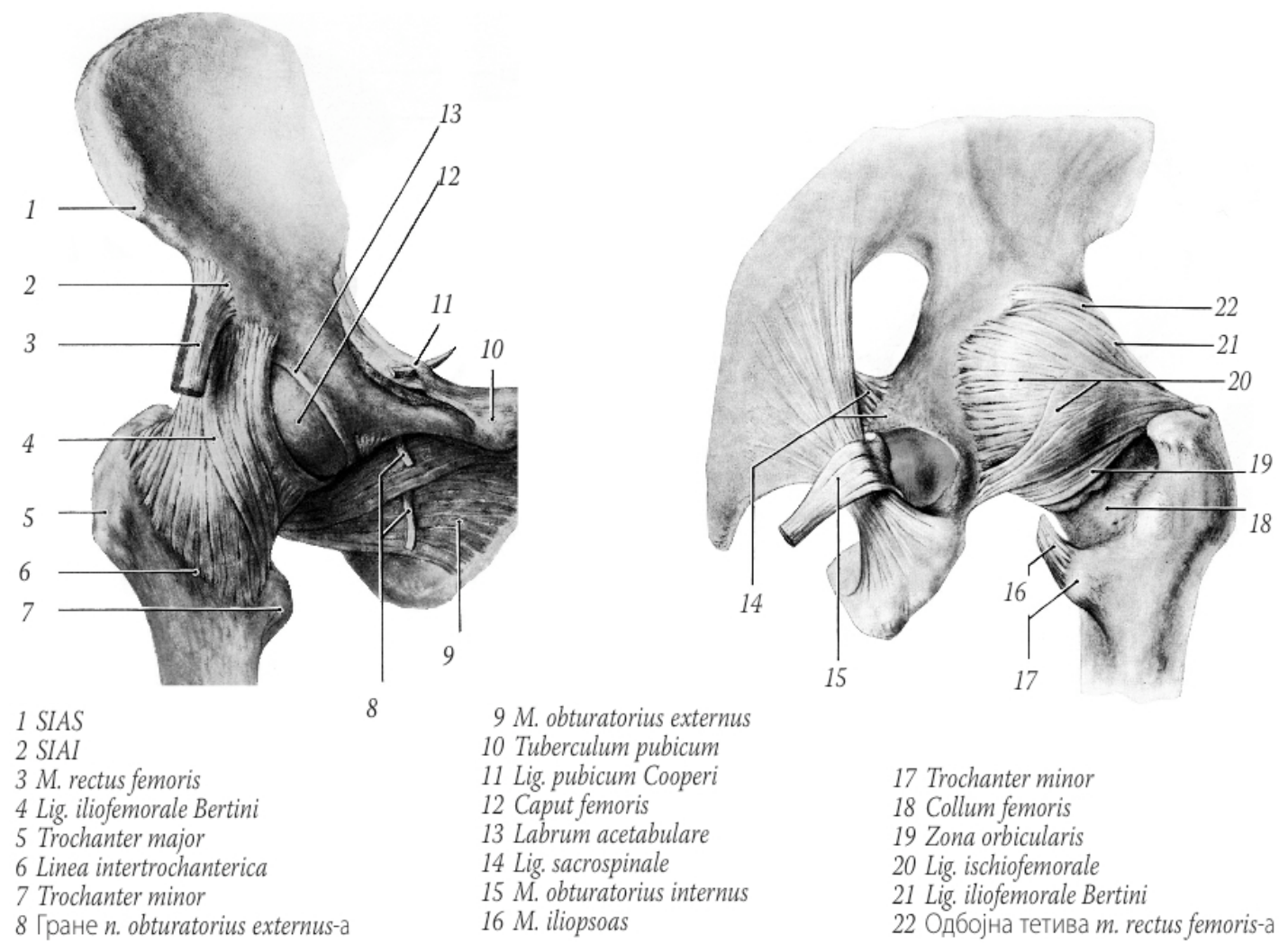

Слика 5: Везе зглоба кука

Извор: Спасовски Д. Функиионална анатомија човека. Excelsior, 2009. 
Из централног незглобног дела ацетабулума (pulvinar acetabuli) полази веза главе бутне кости (lig. capitis femoris) и дистално се припаја у јамици главе фемура (fovea capitis femoris). Осим механичке, ова веза је значајна за исхрану дела главе фемура јер кроз њу у фемур долазе крвни судови ${ }^{1,2,3}$.

\section{Покрети у зглобу кука}

У реалности се у овом зглобу врше покрети карлице према натколеници, и покрети натколенице према карлици (зависно од тога где је тачка ослонца). У анатомији, међутим, арбитрарно је усвојено да се увек описују покрети дисталног према проксималном сегменту. У зглобу кука врше се покрети флексије до 120 степени, екстензије до 20 степени, абдукције до 45 степени, адукције до 15-30 степени, спољашње ротације до 45-60 степени, унутрашње ротације до 30 степени, а при повољном положају (при флексији и абдукцији) и свих 50 степени. Изводи се и покрет кружења ${ }^{4,5,6,7,8}$.

Кинезиолошка анализа покрета у зглобу кука је веома комплексна, недовољно разјашњена и као засебна тема заслужује пажњу која далеко превазилази обим и циљ овог рада9 9 . На овом месту ће стога бити изложен анатомски опис оних мишића који премошћују зглоб кука и притом су од значаја за даље излагање. Многи од њих при покрету имају сасвим посебне функције и заузимају различита места у хијерархији образаца моторне контроле положаја, става и покрета (како зглоба кука, тако и тела у целини) ${ }^{10}$. Мишићи ће бити груписани према свом основном анатомском дејству на зглоб кука, али ће бити набројани уз све оне покрете у којима, макар и делимично, директно учествују.

\section{ФЛЕКСИЈА У ЗГЛОБУ КУКА}

Слабинскобедрени мишић сачињавају два мишића спојена својим доњим деловима: медијални део је велики слабински мишић (m. psoas major), а латерални део чини бедрени мишић (m. iliacus). Понекад постоји и мали слабински мишић (m. psoas minor) као издвојен мишић. Централни припоји $m$. psoas major су на телима пршљенова од Т12 - Л5, на интервертебралним дискусима између тих пршљенова, као и на трансверзалним наставцима свих лумбалних пршљенова. Ако постоји, m. psoas minor се припаја на телу Т12 пршљена. Бедрени мишић се 
припаја у унутрашњој бедреној јами (fossa iliaca interna) на карличној кости. Оба мишића напуштају карлицу кроз мишићни део подпрепонског отвора (lacuna musculorum hiatus subinguinalis) и спајају се у један мишић на путу ка периферном припоју. Периферни припој је на малом трохантеру на фемуру (trochanter minor).

Затезач бутне фасције (m. tensor fasciae latae) је један од мишића спољашње ложе бедра. Централни припој му је на спољашњој усни бедреног гребена (crista iliaca) и предње-горња бедрена бодља (spina iliaca anterior superior, SIAS). Мишић је кратак и наставља се тетивом која улази у састав бедреноголењачног снопа бутне фасције (tractus iliotibialis fasciae latae). Периферно се припаја на спољашњој голењачној (Жердијевој) кврги (tuberculum tibiae Gerdy).

Терзијски мишић (m. sartorius) је изразито дугачак мишић који припада предњој ложи бута. Централно се припаја на предње-горњој бедреној бодљи (spina iliaca anterior superior). Периферни припој је на горњем делу унутрашње стране тибије. Ово је место заједничког припоја сарторијуса и још два мишића бута (m. gracilis, m. semitendinosus), и назива се гушчије стопало (pes anserinus).

Прави мишић бута (m. rectus femoris) најповршнија глава четвороглавог мишића бута (m. quadriceps femoris). Централно се припаја на предње-доњој бедреној бодљи (spina iliaca anterior inferior-SIAI) као и на надстрешици ацетабулума (supercilium acetabuli). У дисталном делу се начелно припаја на

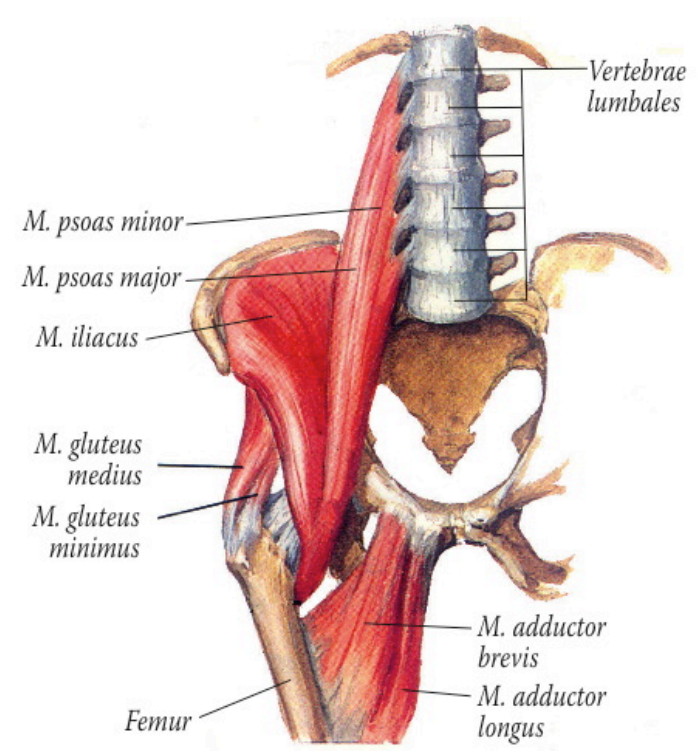

Слика 6: мишићи предње стране зглоба кука Извор: Спасовски Д. Функиионална анатомија човека. Excelsior, 2009. патели. Али, у суштини патела је сезамоидна кост настала у заједничкој тетиви четвороглавог мишића бута при чему влакна правог мишића бута нису на њој прекинута, тако да се у функционалном смислу он у виду пателарног лигамента припаја на голењачном испупчењу (tuberositas tibiae).

Поред ових, у флексији зглоба кука учествују и кратки приводилац бута ( $m$. adductor brevis), горњи сноп великог приводиоца бута (m. adductor 
magnus) само гоњим снопом и то само до 45 степени флексије, витки мишић (m. gracilis) само до 40 степени флексије, чешљасти мишић (m. pectineus), дуги приводилац бута (m. adductor longus) и предњи снопови средњег седалног мишића (m. gluteus medius), али пошто су им неке друге функције доминантније од функције флексије, описани су у припадајућим поглављима у складу са тим.

\section{ЕКСТЕНЗИЈА У ЗГЛОБУ КУКА}

Велики седални мишић (m. gluteus maximus) је највећи и најснажнији мишић седалне регије. Централно се припаја на задњем пољу спољашње бедрене јаме (fossa iliaca externa) иза задње седалне линије (linea glutea posterior); такође се припаја и на бочним странама крсне и репне кости. Периферни припој му је на седалном гребену бутне кости (tuberositas glutea femoris), што представља спољашњу грану трифуркације храпаве линије (linea aspera), задње ивице фемура.

Полуопнасти мишић (m. semimembranosus) припада групи задње ложе бута. У свом горњем делу нема мишићних влакана већ је у виду танке апонеурозе, одакле му потиче име. Централни припој му је на седалној кврги (tuber ischiadicum), а периферни припој на задње-унутрашњој страни медијалог кондила тибије. Од места овог припоја одвајају се одбијена и повратна тетива. Одбијена се припаја у близини директног припоја, а повратна се пружа укосо навише и споља и завршава на задњој страни латералног кондила фемура и спада у задње спољашње лигаменте колена.

Двоглави мишић бута ( $m$. biceps femoris) заузима спољашњи део задње стране натколенице. Дуга глава (caput longum) се централно припаја на седалној кврги (tuber ischiadicum), заједничким припојем са семимембранозусом, а кратка глава (caput breve) на храпавој линији (linea aspera). Периферни припој им је на шиљастом наставку главе фибуле (apex capitis fibulae), а један сноп се припаја и на спољашњем кондилу тибије.

У покрету екстензије у зглобу кука, поред набројаних, учествују и следећи мишићи: средњи седални мишић, својим задњим сноповима (m. gluteus medius), мали седални мишић ( $m$. gluteus minimus), полужиласти мишић (m. semitendinosus), а при флексији у зглобу кука већој од 40 степени и витки мишић (m. gracilis). 


\section{АБДУКЦИЈА У ЗГЛОБУ КУКА}

Средњи седални мишић (m. gluteus medius) лежи испод великог седалног мишића. Централни припој заузима средње поље спољашње бедрене јаме (fossa iliaca externa) између предње и задње седалне линије (linea glutea anterior et posterior). Периферно се припаја на спољашњој страни великог трохантера (trochanter major) фемура.

У покрету абдукције активирају се и прави мишић бута (m. rectus femoris), мали седални мишић ( $m$. gluteus minimus), затезач бутне фасције (m. tensor fasciae latae), велики седални мишић, својим горњим сноповима (m. gluteus maximus), те крушкасти мишић (m. piriformis) и терзијски мишић (m. sartorius).

\section{АДУКЦИЈА У ЗГЛОБУ КУКА}

Кратки приводилац бута (m. adductor brevis) је смештен у удубљем слоју унутрашње ложе бута. Централни припој му је на доњој грани пубичне кости (ramus inferior ossis pubis), а периферни на храпавој линији (linea aspera) у пределу горње трећине тела фемура, као и на чешљастој линија (linea pectinea).

Велики приводилац бута ( $m$. adductor magnus) највећи је и најснажнији мишић унутрашње ложе бута. Има три снопа: горњи, средњи и доњи (који се зове још и задњи, и који је најразвијенији). Централни се припаја на доњој грани пубичне кости (ramus inferior ossis pubis), а припој се наставља и на грану седалне кости (ramus ossis ischii). Периферни припој му је читавом дужином храпаве линије (linea aspera), као и на спољашњој грани њене трифуркације у горњем делу назване седални гребен бутне кости (tuberositas glutea femoris) и на унутрашњој грани њене бифуркације у доњем делу, где се налази и квржица великог приводиоца (tuberculum adductorium).

Витки мишић (m. gracilis) такође припада групи адуктора зглоба кука.

Централно се припаја на доњој грана пубичне кости (ramus inferior ossis pubis) у близини пубичне симфизе (symphysis pubica). Периферни припој се налази на горњем делу унутрашње стране тибије, заједно са припојем сарторијуса и семитендинозуса. Припој се зове гушчије стопало (pes anserinus). 
Чешљасти мишић (m. pectineus) припада унутрашњој групи мишића бута. Централно се припаја на чешљастом гребену (pecten ossis pubis) и препонској кврги (tuberculum pubicum) на карличној кости. Припаја се и на Куперовој препонској вези (lig. pubicum Cooperi). Периферни припој: средња грана трифуркације храпаве линије (linea aspera), означена као чешљаста линија (linea pectinea)

Дуги приводилац бута (m. adductor longus) је смештен унутра од чешљастог мишића. Централни припој му је на препонској кврги (tuberculum pubicum) a периферни на храпавој линији (linea aspera), у пределу средње трећине тела фемура.

У покрету адукције још учествују и доњи снопови великог седалног мишића (m. gluteus maximus).

\section{СПОљАШЬА РОТАЦИЈА У ЗГЛОБУ КУКА}

Покрет спољашње ротације изводе пелвитрохантерични мишићи - група од шест мишића блиске анатомске локализације, сличних одлика и заједничких функција. У ову групу убрајају се: крушкасти мишић (m. piriformis), унутрашњи запорни мишић (m. obturatorius internus), горњи близанац (m. gemellus superior), доњи близанац (m. gemellus inferior), спољашњи запорни мишић (m. obturatorius externus) и четвртасти мишић бута (m. quadratus femoris). Централни припоји су

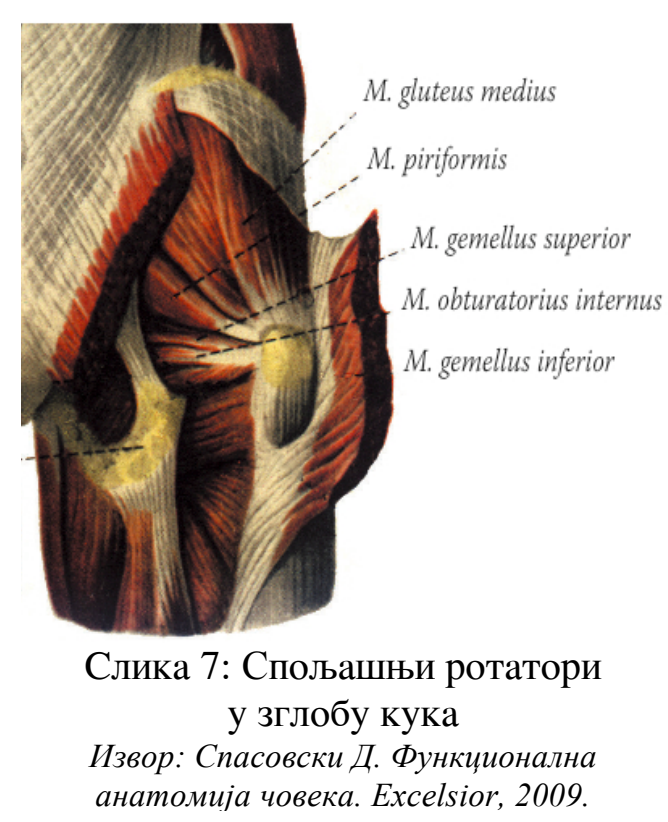
им распоређени на предњој страни сакрума ( $m$. piriformis), спољашњој ( $m$. obturatorius externus) и унутрашњој страни запорне опне ( $m$. obturatorius internus), седалној бодљи (m. gemellus inferior); седалној крврги (m. gemellus superior, $m$. quadratus femoris). Периферни припој им се налази на великом трохантеру (trochanter major) фемура, изузев квадратус фемориса који се припаја на међутрохантерном гребену (crista intertrochanterica). 
Дејство у покрету спољашње ротације у зглобу кука испољавају и велики седални мишић (m. gluteus maximus), терзијски мишић (m. sartorius), задњи снопови средњег седалног мишића (m. gluteus medius), потом кратки приводилац бута (m. adductor brevis), чешљасти мишић (m. pectineus) и дуги приводилац бута (m. adductor longus).

\section{УНУТРАШЊА РОТАЦИЈА У ЗГЛОБУ КУКА}

Мали седални мишић (m. gluteus minimus) лежи испод и испред глутеус медијуса. Централно се припаја на предњем пољу спољашње бедрене јаме (fossa iliaca externa) испред предње седалне линије (linea glutea anterior) Периферни припој му је на предњој ивици великог трохантера (trochanter major) фемура.

Унутрашњој ротацији у зглобу кука доприносе и затезач бутне фасције $(m$. tensor fasciae latae), велики приводилац бута (m. adductor magnus), витки мишић (m. gracilis), средњи седални мишић, задњим сноповима (m. gluteus medius) и полуопнасти мишић (m. semimembranosus)

\section{Развој зглоба кука}

Делови зглоба кука се ембрионално развијају процесима кавитације и диференцијације из мезенхималног ткива ${ }^{11}$, тако да се током седме недеље могу уочити будући ацетабулум и глава бутне кости, у том добу састављени од хрскавице. Током следеће четири недеље довршава се развој детаљних анатомских елемената. Здрав зглоб кука у феталном стадијуму карактерише сферична конгруенција главе фемура и ацетабулума без интерпозиције меких ткива, и добро дефинисан ацетабуларни лабрум оштре слободне ивице.

Код здравих новорођенчади је могуће уочити изражену хипермобилност, али и значајну стабилност кукова, захваљујући равнотежи унутрашњих (подударност зглобних површина и флуидне карактеристике зглобне течности) и спољашњих фактора (тонус мишића који премошћују зглоб кука, еластичног лигамената и зглобне капсуле, као и правац и интензитет резултанте сила у миру и при кретању) $)^{12}$.

Током даљег развитка, по ободу ацетабулума јављају се секундарни осификациони центри: пубични и илијачни у осмој години, а исхијадични у 
годину дана касније. Осификација трирадијатне хрскавице је спор процес: фузије ових епифиза се дешавају тек у периоду од 17-18. године, уз могућност изостанка фузије пубичне епифизе- стање које се назива os acetabuli persistens. Током раста и развоја ацетабулума повећава се и његова дубина, што доприноси побољшању наткровљености и повећању контактне артикуларне површине ${ }^{13}$.

Упоредо са морфолошким развојем ацетабулума, развија се и проксимални окрајак фемура: глава фемура се конгруентно увећава, а њена просторна оријентација мења у правцу смањења колодијафизарног угла и повећања угла антеверзије врата фемура, временом достижући вредности карактеристичне за одраслу доб. Проксимална феморална физа се затвара око 15-16. године код девојчица, а око годину дана касније код дечака.

Важно је нагласити да се интензиван развој зглоба кука у целини и његова матурација дешава током пубертета (период од појаве првих секундарних полних одлика до полне зрелости) и адолесценције (период од успостављања полне зрелости до окончања морфолошког раста и развоја), дакле у условима бурних анатомских и физиолошких промена читавог човечијег организма. У нашој средини се почетак пубертета код девојчица јавља око десете године а завршетак адолесцентног периода дешава око 18. године, док се код дечака процеси померени за око две године касније, уз изражене индивидуалне варијације код оба пола.

Са физиолошке тачке гледишта, раст и развој зглоба кука током периода пубертета и адолесценције је знатно спорији него у дечјем узрасту, те је и физиолошки ремоделациони потенцијал коштаног ткива умањен ${ }^{14}$. Изражена тежња за физичком активношћу и максимални моторички захтеви типични су за период адолесценције, тако да је дијагностика и лечење поремећаја зглоба кука у том периоду, у условима натпросечног оптерећења а непотпуне скелетне зрелости, велики изазов. 


\section{Поремећаји конфигурације зглоба кука у периоду адолесценщије}

У најчешћа и најзначајнија обољења чије се последице испољавају у адолесценцији убрајају се развојни поремаћај кука - РПК, Лег-Калве-Пертесова болест - ЛЦП, епифизиолиза главе фемура - ЕГФ, и постредукциона аваскуларна некроза главе бутне кости - ПАН. Карактеришу их различити патофизиолошки супстрати (неправилна конфигурација и оријентација хипопластичног ацетабулума код РПК, екструзија главе фемура и њена последична сублуксација код ЛЦП, или деформација главе и врата фемура услед склизнућа горње феморалне епифизе са своје анатомске позиције на врху врата фемура код епифизиолизе, или услед јатрогеног оштећења њене васкуларизације код ПАН), и заједнички биомеханички резултат: патолошки однос зглобних површина зглоба

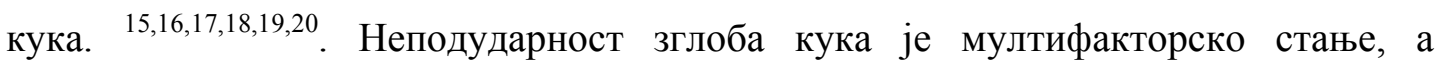
поремећај ацетабулума у најширем смислу те речи је најчешћи узрок. Пошто је ацетабулум тродимензионална структура чија површина која у физиолошким условима одговара одсечку сфере, у геометријском смислу можемо му описати облик, величину и просторну оријентацију у односу на карличну кост, на којој се налази. Свака од набројаних геометријских карактеристика ацетабулума може бити поремећена, и то засебно или у комбинацији са осталима.

Ацетабулум поремећеног облика, односно у торзији, тако да му руб не лежи у једној равни, може довести до спољашњег (pincer) типа синдрома фемороацетабуларног судара.

Величина ацетабулума се процењује на основу поређења са величином главе фемура, тако да премали (односно недовољно велики) ацетабулум се најчешће виђа код последица Пертесове болести (coxa magna, coxa plana, coxa brevis) или епифизиолизе главе бутне кости (pistol grip) са могућом последицом унутрашњег ( cam) типа синдрома феморо-ацетабуларног судара.

Најчешће дијагностиковани поремећај ацетабулума је везан за погрешну оријентацију, због чега се на ово стање и примењује термин дисплазија (грч. $\delta v \sigma-$ лоше $+\pi \lambda \dot{\alpha} \theta \omega$ - створити, направити). Оријентација ацетабулума се дефинише пројекцијом руба ацетабулума на три стандардне анатомске равни, односно помоћу три угла. 
- $\quad$ У фронталној равни то је ацетабуларни индекс, али се код одраслих рутински користи Вибергов ЦЕ (central edge) угао, као мера наткровљености главе бутне кости ацетабулумом ${ }^{21}$.

- $\quad$ У хоризонталној равни описује се степен ацетабуларне верзије, која може бити антеверзија (отвореност ацетабулума пут напред и упоље, што је карактеристика здравих кукова) или ретроверзија (отвореност ацетабулума пут назад и упоље). Код присутне ретроверзије ацетабулума значајну улогу игра и начин снимања радиограма карлице са куковима: наиме, ретроверзија ацетабулума уочена на снимку начињеном у лежећем положају се у највећем броју случајева изгуби уколико се радиограм сачини у стојећем ставу ${ }^{22}$.

- $\quad$ У сагиталној равни се описује ацетабуларна ротација (tilt) која код здравих кукова према истраживању Фуџија и сар. износи 21,1+/-7,3 степена пут уназад, а код диспластичних кукова износи просечно преко 25 степени $^{23}$. Овај налаз потврђује клиничко запажање да је при оперативној реоријентацији ацетабулума повољно извршити и ротацију пут напред.

\section{ДИЈАГНОСТИКА}

Најчешћи симптоми који указују на присуство поремећаја зглоба кука у посматраном узрасту су болне тегобе, измењени став тела и поремећај хода.

Клиничким прегледом се најчешће уочава ограничење обима покрета (нарочито ротаторних), појава Тренделенбурговог знака ${ }^{24}$ и гегајућег хода (поремећај нивелације карлице у фронталној равни изазван ослабљеном функцијом мишића абдуктора оболелог зглоба), као и храмања (поремећај обрасца и ритма хода неусловљен нивелацијом карлице). Биохемијске и друге лабораторијске анализе су неопходне ради евалуације диференцијалнодијагностичких околности, као и у склопу планирања даљег лечења.

Значајно место у дијагностици заузима визуелизација конфигурације карлице и зглобова кука. Од више доступних метода, радиограм је најповољнија за коришћење и у пракси најзаступљенија. 
Описан је велики број стандардизованих метода прецизног мерења различитих зглобних параметара на радиограму, значајних за одређивање стадијума болести и индиковање оптималног метода лечења. Најчешће коришћене радиографске величине у процени поремећаја конфигурације зглоба кука у адолесцентном периоду $\mathrm{cy}^{21}$ :

1. Ацетабуларни угао (Хилгенрајнер) - чине га линија повучена кроз трирадијатне хрскавице, и линија која спаја трирадијатну хрскавицу и највишу тачку ацетабулума.

2. Сферичност главе фемура (Мозе) - уклапање контуре главе фемура у што мањи број концентричних кругова на Мозеовом кружном лењиру.

3. Латерални ЦЕ угао (Виберг) - чине га линије које пролазе кроз центар главе фемура: једна је вертикална, а друга додирује руб крова ацетабулума.

4. Ацетабуларни индекс (Хејман-Херндон) - однос дубине и пречника ацетабулума.

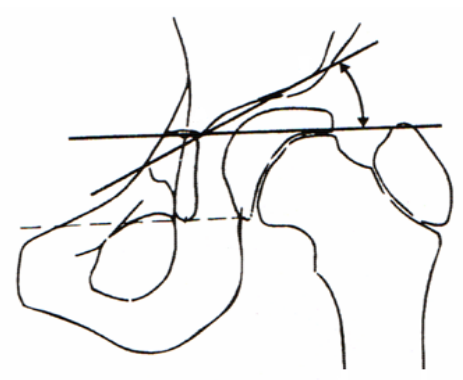

Слика 8: Ацетабуларни угао

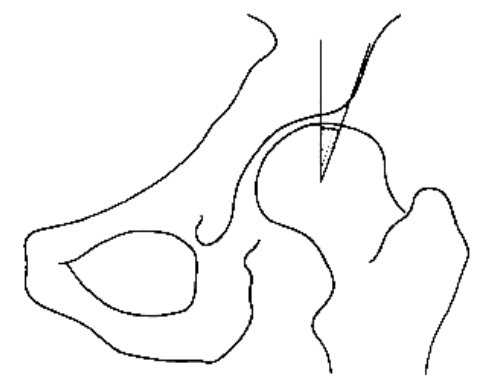

Слика 10: Вибергов ЦЕ угао

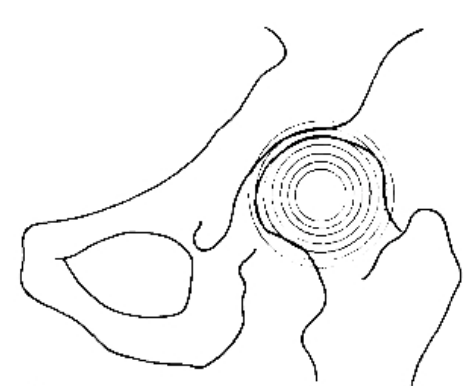

Слика 9: Сферичност главе фемура

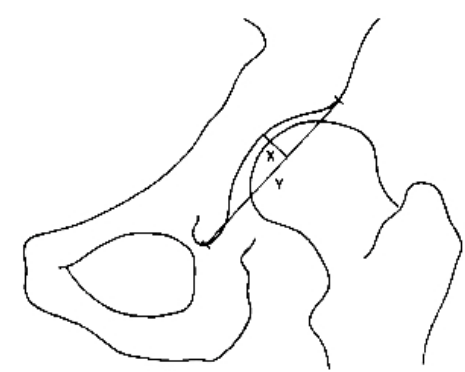

Слика 11: Ацетабуларни индекс

Извор за слике 8-11: Vukašinović Z, Zajić Lj, Vukadin O. Radiographic assessment of the hip by measurement of different angles and indices. Acta Orthop Iugosl 1997; 28:27-31. 


\section{ЛЕЧЕњЕ}

У периоду адолесценције ацетабуларна дисплазија, посебно блага и изолована, често не даје никакве симптоме. Стога се као општи циљ лечења дисплазије кука у овом узрасту намеће се превенција превремене дегенерације зглоба и раног инвалидитета ${ }^{16,25,26,27,28,29,30}$. Међутим, уколико је у том смислу неопходно применити оперативно лечење, како одабрати најадекватнију процедуру и најпогоднији моменат? Више студија је рађено са циљем изналажења објективних критеријума погодних за одлуку о оперативном лечењу са што бољим исходом ${ }^{25}$. Има мишљења да је важно хируршки кориговати дисплазију у периоду пре затварања проксималне феморалне епифизе, а поготово пре почетка болних тегоба ${ }^{31}$. Појава бола најављује брзу прогресију дегенеративних промена, и тада примењено реконструктивно лечење не даје добар резултат. Ипак, има аутора који наводе успех након примене реконструктивног лечења и у одмаклој фази болести ${ }^{32,33,34,35}$.

Операције наткровљавања ("шелф"), некада широко примењиване, данас имају историјски значај. Савремени приступ лечењу дисплазије ацетабулума и других поремећаја конгруенције зглоба кука обухвата остеотомије карлице $\mathrm{e}^{36,37}$. У односу на оперативни циљ остеотомије карлице се деле на две основне групе: реконструктивне остеотомије и остеотомије спаса.

Реконструктивне остеотомије карлице имају за циљ корекцију дисплазије и превенцију коксартрозе путем измене положаја ацетабулума у односу на правац резултујуће силе у зглобу кука. Тиме се механички услови у зглобу приближавају физиолошким и представљају квалитетан стимулус за дуготрајни процес природне ремоделације ацетабулума ${ }^{25,38}$. Општи услови за реконструктивне остеотомије су: узраст млађи од 25 година; минимални симптоми уз прогресију; значајно очуван обим покрета; одсуство трајних дегенеративних промена хрскавице, и конгруентност зглоба кука ${ }^{32,39}$. У рекоструктивне остеотомије убрајају се Салтерова (једнострука) остеотомија, двоструке остеотомије карлице, троструке остеотомије карлице и периацетабуларне остеотомије.

Остеотомије спаса су усмерене на побољшање функције оштећеног зглоба и одлагање артропластике. Пример остеотомије спаса је Кјаријева остеотомија карлице, која је индикована код кукова који су инконгруентни и нестабилни у 
адолесцентном узрасту пацијента. Уколико се уради благовремено и прецизно, овом методом се може очекивати задовољавајући дуготрајни резултат $30,40,41,42,43,44$.

Очигледно је да реконструктивне остеотомије у начелу имају предност над другим методама лечења, те да Кјаријева остеотомија представља изнуђено решење у ситуацији када критеријуми за примену реконструктивних остеотомија нису испуњени, а ни примена алоартропластике зглоба кука не би довела до задовољавајућег дугорочног резултата ${ }^{44}$.

\section{Салтерова остеотомија карлице}

Салтерова остеотомија карлице је описана 1961. године као хируршки метод који се базира на чињеници да суштина дисплазије кука није само у дефекту крова ацетабулума, већ и у ротацији уназад и претераној абдукцији читавог ацетабулума. Остеотомијом илијачне кости и дислокацијом дисталног (ацетабуларног) фрагмента пут напред, наниже и упоље, постиже се побољшање

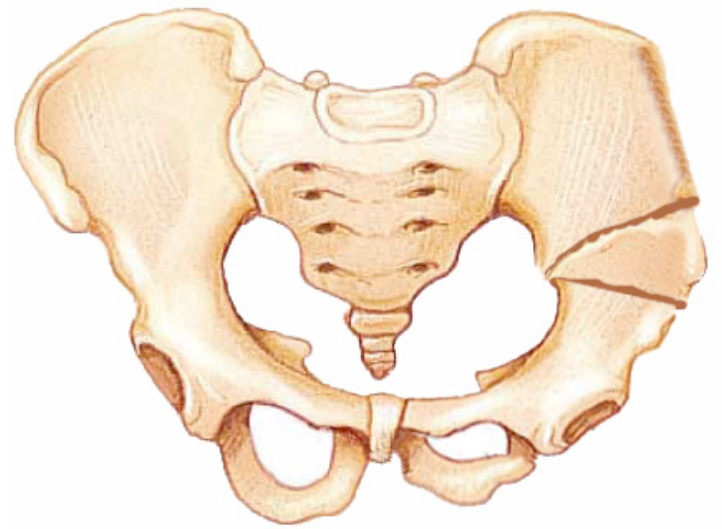

Слика 12: Салтерова остеотомија карлице наткровљености главе фемура без промене облика нити запремине самог ацетабулума $^{45}$. Пошто се дислокација ацетабуларног фрагмента након остеотомије остварује ротирањем у самој несраслој пубичној симфизи, прве операције су урађене у склопу оперативног лечења луксације кука код деце узраста од 18 месеци до шест година. Међутим, аутор је навео и да је овим путем могуће лечити и сублуксације присутне чак и у адолесценцији и код млађих одраслих ${ }^{32,39}$. При реоријентацији ацетабулума код Салтерове остеотомије неминовно долази и до његовог спуштања, што доводи до продужења екстремитета и до повећања притиска у оперисаном зглобу. Како би се ово предупредило, остеотомији карлице се у истом акту додаје абревијациона остеотомија фемура ${ }^{18,46}$. Додатна деротација ради побољшања наткровљености и конгруенције је у почетку рађена, али је накнадно напуштена као непотребна $a^{47,48,49}$. Побољшање покрета и додатно растерећење зглоба кука 
постиже се додатном дезинсерцијом карлице према Кембелу, тенотомијом илиопсоаса и евентуалном тенотомијом адуктора фемура.

Кјаријева остеотомија карлице

Кјари је 1955. године описао технику остеотомије карлице са медијализацијом дисталног фрагмента, у циљу стварања добро васкуларизоване коштане платформе изнад главе фемура, уз интерпозицију зглобне капсуле ${ }^{50}$.

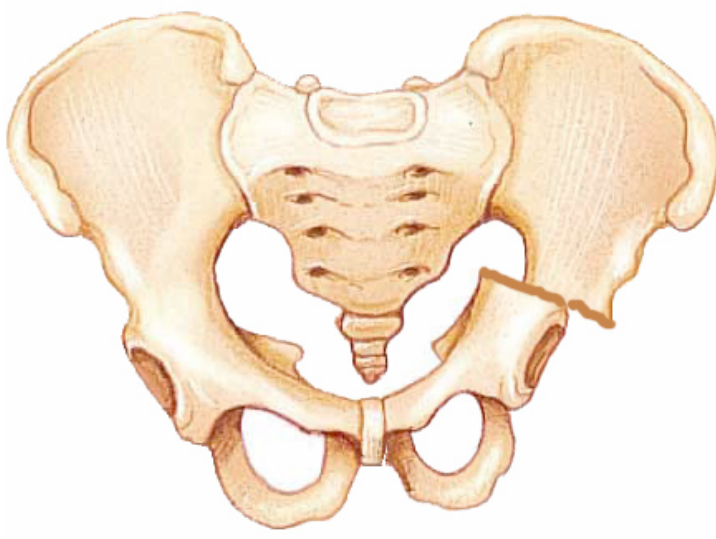

Општи услов за њену примену је очуван функционални обим покрета у зглобу кука ${ }^{51}$. Има аутора који као додатни услов наводе и одсуство значајних остеоартротичних промена ${ }^{16,19,52,53,54}$. Може се користити и код сублуксације кука, под условом је технички изводљиво правилно оријенСлика 13: Кјаријева остеотомија карлице тисање равни остеотомије ${ }^{43}$.

О примени Кјаријеве остео-томије карлице у лечењу изоловане дисплазије кука у адолесцентном периоду нема пуно саопштења. Она је углавном примењивана код Пертесове болести, у случајевима када је глава фемура екструдирана и деформисана уз губитак подударности зглобних површина ${ }^{44,54}$. Пошто нема утицаја на конгруенцију зглоба кука, Кјаријева остеотомија не зауставља прогресију дегенеративног процеса, до кога након различитог временског периода ипак неминовно долази ${ }^{40,51,53,55,56}$. Ипак, поједини аутори на основу солидних резултата код пацијената који још увек немају симптоме ни знаке одмаклих дегенеративних промена, Кјаријеву остеотомију чак третирају пре као профилактичку операцију, него као остеотомију спаса ${ }^{57}$.

Уз Кјаријеву остеотомију се обично изводи и премештање (латерализација и дистализација) великог трохантера, ради побољшања крака силе абдукторних мишића. Скраћивање фемура најчешће није потребно, али има и другачијих мишљења ${ }^{19,32}$. 


\section{Трострука остеотомија карлице}

Применом Салтерове и Кјаријеве остеотомије илијачне кости код пацијената у адолесценцији, уочени су извесни недостаци.

Услед смањене еластичности пубичне симфизе, код пацијената старијих од 10 година Салтеровом остеотомијом се није могла постићи довољно добра реоријентација диспластичног ацетабулума ${ }^{47}$. Поред тога, дистализација ацетабулума изискује оперативно скраћивање фемура у субтрохантерној регији, јер у противном долази до функционалног продужења ноге и повећаног притиска зглобних хрскавица са убрзавањем настанка дегенеративних промена ${ }^{26,27,28,29,47}$.

Кјаријева остеотомија за последицу има функционално скраћење оперисане ноге уз тенденцију настанка гегајућег хода ${ }^{26,27,28,29,30}$. Додирну површину на новоформираном продужетку ацетабулума не чини хијалина хрскавица већ везивно ткиво (зглобна капсула) које временом услед механичке стимулације метаплазира у фиброзну хрскавицу. Такође, код млађих пацијената описано је и оштећење ацетабуларне хрскавице раста са поремећеним развојем ацетабулума ${ }^{44}$.

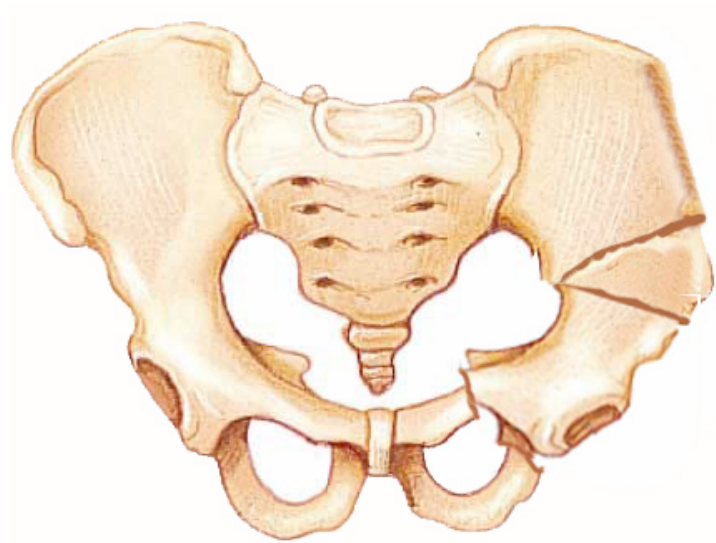

Слика 14: Трострука остеотомија карлице

У циљу успешнијег решавања поремећаја подударности зглобних површина зглоба кука $\mathrm{y}$ адолесцентном узрасту, у праксу су уведене двоструке, потом и троструке остеотомије карлице ${ }^{58}$. Данас оне представљају најсавременији метод оперативног лечења поремећаја центраже, покривености и садржаности зглоба кука за узраст старији од 10 година. Општи услов за њихову примену је сферична конгруенција ацетабулума и главе фемура, очуван функционални обим покрета у том зглобу, као и одсуство значајних дегенеративних промена ${ }^{32,48,59}$. Не примењују се код луксација кука и отвореност трирадијатне хрскавице, док старост преко 25 година представља фактор ризика за прогресију оштећења зглоба ${ }^{60,86}$.

Према удаљености места остеотомија кости карлице од ацетабулума, троструке остеотомије могу поделити на три групе: параацетабуларне (где је 
илијачна остеотомија на истом месту као и код Салтерове остеотомије, а пубична и исхијадична релативно далеко од ацетабулума), пери- односно јукстаацетабуларне (илијачна остеотомија је на непромењеном месту, а друге две кости се остеотомирају ближе ацетабулуму) и ацетабуларне остеотомије (остеотомије су сасвим близу ацетабулума, толико да се карлични прстен и не прекида).

\section{Тенисова трострука остеотомија карлище}

Тенисова трострука остеотомија карлице припада групи периацетабуларних остеотомија, што омогућава велику антеролатералну ротацију ацетабуларног фрагмента и значајан наткровљавајући учинак. Оригиналну технику троструке остеотомије аутор је објавио 1981. године ${ }^{28,61,62}$, а у нашу средину је уведена 1996. године и то у Институту за ортопедско-хируршке болести -“Бањица” у Београду $^{63}$. Од тада до данас урађено је више од 100 оваквих операција ${ }^{64}$. Као плод систематске хируршке евалуације резултата са једне, али и изражене професионалне сарадње са аутором методе као и са водећим европским хирурзима на овом пољу, током примене је осавремењена увођењем модификације хируршког приступа пубичној и исхијадичној кости без сечења адукторне мускулатуре, описане од стране Владимирова ${ }^{28,65}$.

\section{ОПЕРАТИВНА ТЕХНИКА}

Пацијент лежи на леђима, нога на страни операције постави се у положај флексије и абдукције. Оперативни приступ код Тенисове троструке остеотомије састоји се из два дела. У првом делу се кроз медијални рез тупом препарацијом најпре између пектинеуса и адуктор лонгуса (уз његову парцијалну дезинсерцију са горње гране пубичне кости) а потом у дубоком слоју латерално од адуктор бревиса и изнад оптураторијус екстернуса приступи грани исхијадичне кости који се потом остеотомира. Кроз исти оперативни рез се потом приступи и горњој грани пубичне кости непосредно медијално од оптураторног сулкуса, где се длетом уради остеотомија у равни паралелној уздужној оси тела или усмереној благо медиокранијално. Потом се нога испружи и пацијент врати у стандарни лежећи положај, те се предњим приступом уради остеотомија крила илијачне 
кости од великог седалног усека до предње ивице карличне кости. Затим се обави реоријентација слободног ацетабуларног фрагмента, и након постизања жељене корекције ацетабуларни фрагмент се у новој позицији стабилизује према илијачном крилу Киршнеровим иглама или Ноулсовим завртњем, уз интерпозицију клинастог калема узетог са предњег дела бедреног гребена.

Постоперативно се не примењује имобилизација, а рехабилитација почиње већ трећег постоперативног дана. Након око две недеље пацијент се вертикализује уз штаке и додирни ослонац на оперисану ногу, а прогресија до пуног ослонца обично траје 3-4 месеца, након радиографске верификације зарастања остеотомираних костију.

Компликације које прате овај хируршки поступак су малобројне и најчешће не ремете жељени резултат. Поред увек могућих општих ортопедских компликације (крвављење, инфекција ране), код троструке остеотомије су уочене и одређене специфичне компликације уско везане за овај тип оперативног захвата. Описују се лезија $n$. cutaneus femoris lateralis током хируршког приступа, оштећење или иритација исхијадичног нерва приликом остеотомије исхијадичне кости, повреда комуникантних крвних судова у пределу адукторне регије при медијалном хируршком приступу, настанак хетеротопних осификација, несрастање остеотомираних пубичних или исхијадичних фрагмената, продор остеофиксационог материјала у зглоб са оштећењем Зглобних површина, редислокација остеотомираног ацетабуларног фрагмента $23,48,66,67,68$.

\section{Биомеханика зглоба кука}

\section{ВРСТЕ И РАЗВОЈ МЕТОДА ИСПИТИВАҢА}

На развој скелета значајно утичу механичке силе које на његове делове свакодневно делују. На зглоб кука, као носећи зглоб кугластог типа, делују многобројне силе различитих праваца и смерова, интензитета и трајања, сумирајући се у центру ротације зглоба, који у физиолошким условима одговара центру главе фемура. Резултанта сила може имати различиту просторну оријентацију и интензитет, што значајно утиче на њену дистрибуцију дуж сферичних контактних зглобних површина. Уколико су параметри резултанте 
сила у физиолошким границама, према Хојтер-Фолкмановом закону она стимулативно делује на развој зглоба кука ${ }^{69}$. У супротном случају долази до стварања услова најпре за поремећај развоја зглоба, а касније и његову дегенерацију.

Почетком седамдесетих година појављују се саопштења која говоре о значају расподеле силе притиска у зглобу кука ${ }^{70,71,72}$. Пауелс је 1978. године констатовао да повишени контактни притисак у пределу ацетабуларног крова изазива апозицију кости и дегенеративне промене. Научно интересовање се усмерава ка истраживању биомеханичких фактора телесне конституције и њиховог утицаја у физиолошким условима а нарочито у патолошким стањима зглоба кука. Бројни клинички и радиолошки параметри, као резултат примене оперативних метода, анализирани су најчешће ин виво, на самим пацијентима. Прецизнија испитивања непосредног биомеханичког ефекта на ткива зглоба кука су потом рађена у лабораторијским условима, ex vivo на кадаверичним или механичким моделима као и in vivo употребом интраартикуларних сензора (парцијалне протезе са уграђеним сензорима ${ }^{73}$, интерпозициони филмови осетљиви на притисак ${ }^{74,75}$, а у новије време и фибероптички сензори ${ }^{76}$ ), најчешће на кадаверичном моделу, али је успешно успостављен и анимални модел ${ }^{77}$. Паралелно са тим приступом, у последње четири деценије развијено је више модела који описују биомеханичка својства зглоба кука, аналитичких ${ }^{7178,79,80,81}$ као и нумеричких (заснованих на методи анализе коначних елемената) $82,83,84,85,86,87,88,89$. Примена математичког моделовања ${ }^{90,91}$ довела до експанзије испитивања карактеристика дистрибуције силе притиска и њених клиничких последица. Ова експанзија је искористила глобалну информатичку револуцију, и последичну системску примену рачунара у биомедицини ${ }^{92,93}$. Тиме је омогућена анализа морфолошких параметара самог пацијента (добијених нативном радиографијом, ЦТ или НМР визуелизацијом), и прорачун величине, правца и интензитета сила које делују на зглоб кука у физиолошким условима и различитим патолошким стањима, пре и након примене оперативних захвата. Математичко моделовање зглоба кука омогућава боље разумевање процеса развоја ацетабулума, као и ранију и прецизнију квантитативну и квалитативну анализу поремећаја тог развоја, тако да је и клиничка употреба различитих модела у експанзији. Упоредо 
са тиме расте и број саопштења која потврђују валидност овако добијених података, те њихову глобалну сагласност како са лабораторијским мерењима, тако и са клиничким налазима.

Примена математичког моделовања зглобова има и своја ограничења. На пример, мерења путем уградње сензора имају значајно ограничење у чињеници да присуство вештачког материјала у зглобу мења физиолошки ток флуида кроз зглобни простор али и кроз слојеве хрскавице, чиме се мењају њена биомеханичка својства ${ }^{94}$.

Вредности које описују промене биомеханичких параметара зглоба кука при покретима имају још мању поузданост, из више разлога. Примена инвазивних маркера (пласираних кроз кожу у проминентне и доступне делове костију) је неподесна за анализу in vivo, и представља етички проблем јер је инвазивна и није део стандардног дијагностичког или терапијског поступка. Код примене кутаних маркера (најчешће инфрацрвених) јавља се нови извор варирања: то је релативна покретљивост коже и маркера на њој у односу на кост, и грешка може износити и преко два центиметра ${ }^{95}$. И поред наведених ограничења, примена математичких модела у ортопедији има велики значај и употребну вредност.

\section{БИОМЕХАНИЧКЕ ОСОБИНЕ ЗГЛОБА КУКА}

Зглоб кука човека није идеално сферичног облика. Савремена технологија тродимензионалне реконструкције код снимања нуклеарном магнетном резонанцом (НМР) и компјутеризованом томографијом (ЦТ) омогућава индивидуалну адаптацију стандардних модела базираних на анализи коначних елемената, што води повећању прецизности резултата, али такође и времена неопходног за израду, као и цене. Већина математичких модела, зато, врши апроксимацију идеалне сферичности, а истраживања потврђују да тако добијени резултати не одступају значајно од реалних вредности ${ }^{86}$.

У морфолошке параметре који значајно утичу на дистрибуцију силе у зглобу кука убрајају су величина Виберговог ЦЕ угла (као мера степена наткровљености зглоба), пречник главе фемура, ширина и висина карлице и позиција великог трохантера. Показано је да Вибергов ЦЕ угао негативно корелира са максималном силом притиска у зглобу (нормализованом према телесној тежини), а позитивно 
са величином носеће површине зглоба, те да терапијски поступци који повећавају ту носећу површину и смањују силу притиска на зглобне површине могу продужити ьихов век ${ }^{79,96,97,98,99,100,101,102}$. У присуству дисплазије зглоба кука дегенеративне промене настају брже и извесније: Вибергов ЦЕ угао мањи од 16 степени је фактор лоше прогнозе. При томе, сматра се да чак 20-50\% случајева коксартрозе настаје на терену дисплазије кука ${ }^{33,103,104}$.

Механичка својства зглобне хрскавице су предмет великог научног интересовања и истраживања. Њену окосницу чини мрежа колагених влакана, формирана тако да садржи и микропоре које омогућавају лакше дифузију синовијалне течности. Досада је објављено више биомеханичких модела хијалине хрскавице. Применом пороеластичног монофазног модела (кога карактерише нестишљивост и хипереластичност), показано је да уколико сила непрекидно делује довољно дуго, током времена долази до деформације хрскавице уз смањење максималног притиска ${ }^{83,105,106,107}$. Други аутори описују бифазични модел, према коме се својства хрскавице истражују и објашњавају високу отпорност на притисак и низак коефицијент трења (измерен у опсегу од 0,0010,02 ) присуством солидне (матрикс) и флуидне фазе (осмотски упијена синовијална течност). Овако мали коефицијент трења постоји захваљујући томе што течна фаза преузима и до 90\% оптерећења на ацетабуларну хрскавицу, и тиме умањује силу која се преноси контактом чврсто-на-чврсто (солидна фаза и субхондрална кост). Проценат воде у хрскавици је око $80 \%$, а пермеабилност $\mathrm{k}=9.83 \times 10-16 \mathrm{~m} 4 / \mathrm{Ns}^{108,109,110,111,112,113,114,115,116,117}$. Приликом континуираног статичког оптерећења у стојећем ставу, ацетабуларна хрскавица смањује проценат течности у својим слојевима и то за око 1,2\% код здравих кукова и чак 7,6\% код код диспластичних ${ }^{118}$. Међутим, брзина повећања оптерећења ацетабуларне хрскавице приликом покрета који карактеришу нормалне свакодневне активности је довољно велика тако да губитак течности из ње том приликом није значајан, те се одговор на оптерећење не разликује од пороеластичног модела ${ }^{110,119,120,121}$. Прецизна мерења нуклеарном магнетном резонанцом утврдила су да пластична деформација хрскавице спор процес: под континуираним утицајем силе од $1980 \mathrm{~N}$ (што одговара оптерећењу одраслог човека у фази једноножног ослонца) ацетабуларна хрскавица се спљошти за просечно $30,9 \%$ од почетне дебљине. 
Време потребно за овај процес је 225 минута, при чему се петина деформације догоди у првих 15 минута, а 50\% деформације за око 50 минута. Потпуну реституцију након укидања силе траје знатно више: 16,5 сати ${ }^{122}$. Сличне резултате на зглобу кука, али и другим зглобовима, приказали су и други истраживачи ${ }^{123,124}$.

Бранд $^{125}$ (2005) наводи да се максимални притисак на ацетабуларну хрскавицу се креће у опсегу од 2-10 МРa, а од раније је познато да је око хиљаду циклуса импулсног притиска од $25 \mathrm{MPa}$ довољно да изазове некрозу хондроцита, тиме и дегенерацију хрскавице ${ }^{126}$. Ипак, просечне вредности притиска у здравом зглобу кука су срећом за ред величине мање од ове ${ }^{90,127}$.

Зависно од методе мерења, постоје значајна варирања биолошких својстава хрскавице. На пример, за Јангов линеарни модус еластичности опсег прорачунатих вредности је од 0,5-20 $\mathrm{MPa}^{128,129}$. Употребом нелинеарних модела, Муни-Ривинов линеарно-еластични модус има вредности од 0,3-4 MPa ${ }^{130,131}$.

Појава тангенцијалне силе истезања слојева хрскавице у присуству неподударности зглобних површина довођена је у везу са променом њихове протеосинтетске активности, уз последичну промену састава и смањење пермеабилности хрскавице, што је повезано са дегенеративним њеним променама ${ }^{132}$.

За нормално функционисање зглоба неопходна је одговарајућа развијеност и очувани интегритет не само хрскавице, већ и ацетабуларног лабрума и других зглобних структура ${ }^{133}$. Уочено је да ацетабуларна усна (labrum acetabuli) и њен физиолошки наставак- попречна чашична веза (ligamentum transversum acetabuli) преграђују зглобни простор на два сегмента: централни простор (унутар лабрума и између зглобних површина) и периферни простор (између врата бутне кости и зглобне капсуле). Процењено је да лабрум преузима мање од 3\% оптерећења код здравог зглоба кука, али од 4-11\% оптерећења када је у питању диспластичан кук ${ }^{88}$. Такође, синовијална течност коју он при оптерећењу држи заробљену у централном зглобном простору игра значајну улогу у механици зглоба кука. Након ексцизије лабрума, на пример, максимални притисак синовијалне течности у централном простору је мањи за просечно $0,33 \mathrm{MPa}^{128}$. Поред дисплазије зглоба кука, и оштећење ацетабуларног лабрума представља фактор настанка дегенеративних промена артикуларне хрскавице. Ова два фактора имају и своју 
компликовану међузависност: наиме, оштећења лабрума су чешћа и већег обима у присуству дисплазије кука ${ }^{134,135,136}$, али такође и оштећени лабрум представља окидач за дегенеративне промене и то најчешће у постеросупериорном делу ацетабулума ${ }^{95,137,138}$. Са овим запажањем се слажу и Лубовски и сар., који су мерењем разлике анатомске оријентације ацетабулума и "функционалне" оријентације (изражене кроз испитивање позиције односно нагиба хиперкалцификоване субхондралне кости, односно такозване "ацетабуларне обрве") посредно показали да управо тај део ацетабулума трпи највеће кумулативно оптерећење ${ }^{139}$. Према њиховим резултатима, најоптерећенији део ацетабулума је издужена калота (овоидни одсечак сфере) чија осовина, посматрано из центра ротације зглоба кука, има оријентацију од 33,3+/-7,1 степени у фронталној равни пут медијално, и 29,2+/-11,4 степена у сагиталној равни пут позади. Аутори нису детаљно обрађивали разлику у густини унутар калоте, која би одражавала разлику у интензитету силе притиска на тај део ацетабуларне хрскавице.

Постоји сагласност да је величина, дистрибуција и трајање контактног притиска на хрскавицу зглоба кука један од фактора настанка коксартрозе $\mathrm{140,141,142,143}$, те је његова процена неопходна за разумевање суштине патолошког процеса, квалитетно преоперативно планирање и постоперативну рехабилитацију 95 . Ограничавајући фактор у истраживањима утицаја оперативног лечења на превенцију коксартрозе је чињеница да се преоперативни негативни утицај тог фактора на артикуларну хрскавицу не може ретроактивно елиминисати. Ово је нарочито важно узевши у обзир велики просечни број циклуса покрета годишње (1,3-2,5 милиона). У том смислу, прекасно индиковање оперативног лечења сматра се предиктивним фактором лошег резултата ${ }^{144}$.

На величину и правац резултантне силе у зглобу кука утиче позиција великог трохантера, као и позиција центра ротације зглоба кука у односу на карлични прстен. Показано је да се интензитет силе смањује са латерализацијом великог трохантера, али још више и са медијализацијом центра ротације зглоба ${ }^{81,145}$.

Што се тиче утицаја разлика у телесној конституцији мушког и женског пола, уочено је да је код жена контактни притисак значајно већи за просечно око 
$20 \%$, и то услед мањег пречника главе фемура код жена, док разлике у ширини и облику карлице нису од битног значаја ${ }^{146}$.

\section{ТРОДИМЕНЗИОНАЛНИ МАТЕМАТИЧКИ МОДЕЛ ЗГЛОБА КУКА}

У стручној литератури описано је више математичких модела зглоба кука базираних на радиографији. У овом истраживању употребљен је тродимензионални модел зглоба кука базиран на стандардној нативној радиографији карлице са куковима у антеропостериорној (АП) пројекцији, креиран од стране групе аутора из Лабораторије за биофизику Електротехничког факултета Универзитета у Љубљани (Словенија) и објављен 1990. године ${ }^{147}$. Одабран је захваљујући следећим карактеристикама:

- одлична теоријско-методолошка подршка у објављеној литератури,

- релативно једноставна техника мерења,

- доступност рачунарског програма који олакшава унос полазних морфолошких параметара зглоба кука и карличног прстена, и потом прецизна израчунавања излазних вредности модела- параметара дистрибуције силе притиска на ацетабуларну хрскавицу.

Нативни радиограм карлице са куковима у АП пројекцији је обавезни дијагностички поступак код многих поремећаја зглоба кука код човека, радиографски базиран модел има значајну практичну предност а сасвим задовољавајућу прецизност (валидност износи око 90\%) у односу на сложеније, ЦТ- и НМР-базиране моделе ${ }^{148,149}$.

Модел омогућава израчунавање неколико важних биомеханичких параметара за које је накнадним истраживањима утврђено да могу представљати значајне предикторе тока дисплазије, настанка и развоја дегенеративних промена зглоба кука ${ }^{150}$. Он подразумева еластичну деформацију контактних зглобних површина ацетабулума и главе фемура, дефинише појам носеће површине зглоба и омогућава квантификацију разлике у дистрибуцији силе у здравом и диспластичном зглобу. 
Као и код сваког математичког модела, и овде постоје одређене апроксимације и услови који важе при његовој употреби и интерпретацији резултата:

- Занемарује се вискозност зглобне течности;

- Занемарује се површински напон зглобне течности;

- Занемарују се електростатичке силе између зглобних површина;

- Занемарује се сила трења између зглобних површина: процена параметара силе у зглобу кука се односи на статички режим оптерећења;

- Модел подразумева сферичне и конгруентне зглобне површине;

- Центри ротације оба зглоба кука се налазе у фронталној равни (занемарују се асиметрије карлице испољене у хоризонталној равни);

- Тежиште ослањајућег дела тела при једноножном ослонцу (изузимајући ослањајућу ногу) у средини периода једноножног ослонца при спором ходу или стајању, припада истој тој фронталној равни;

- Тродимензионални математички модел словеначких аутора апстрахује вискоеластична својства коштаног ткива. Мерењем у лабораторијским условима установљено је да кости имају Јангов модул еластичности $\mathrm{E}=12$ Мра, и Пуасонов количник $v=0,42^{107}$ што може створити значајно одступање од реалних вредности ${ }^{151}$.

И поред наведених апроксимација и услова, упрошћени тродимензионални модел зглоба кука базиран на нативног радиографији у АП пројекцији је веома клинички употребљив и у пракси најшире присутан. Објављени су резултати његове примене на анализу здравих зглобова и диспластичних зглобова кука, као и зглобова кука оперисаних различитим методама: центражне остеотомије фемура, Салтерова, Кјаријева и Ганцова остеотомија карлице.

У овом истраживању први пут се примењује на анализу и квантификацију учинка Тенисове троструке остеотомије карлице. Она обезбеђује адекватно наткровљавање главе фемура постојећим ацетабулумом, у условима ригидности пубичне симфизе достигнуте физиолошком матурацијом скелета ${ }^{38}$. Ремоделациони потенцијал коштаног ткива у периоду адолесценције као одговор на биолошке, односно механичке стимулусе значајно је мањи него у дечијем 
узрасту. Због тога трострука остеотомија карлице не може да обезбеди излечење до тада насталих механичких оштећења зглоба нити да створи потпуно нормалан зглоб кука ${ }^{32,59}$. Међутим, довођењем ацетабулума и главе фемура у знатно повољнији биомеханички однос очекује се смањење максималне контактне силе притиска у зглобу уз њену побољшану дистрибуцију на зглобним површинама, што утиче на превенцију даљих механичких оштећења, смањује инциденца бола, и значајно продужава животни век зглобних елемената ${ }^{17,32,59,97,101,152}$. Најоштећенији, латерални део ацетабулума спашава се од даљег оштећења измештањем ван површине највеће силе притиска у зглобу ${ }^{38,96,152}$. Постоперативни ЦЕ угао би у идеалном случају требало да буде у опсегу од 25-40 степени, при чему величина корекције ЦЕ угла има дискутабилну вредност у погледу евалуације учинка операције ${ }^{86,153}$. 


\section{ЦИЉЕВИ ИСТРАЖИВАЊА}

1. Дефинисати и одабрати оне биомеханичке параметре који су релевантни за валидну примену тродимензионалног математичког модела (базираног на нативним радиограмима) на зглоб кука пре и после троструке остеотомије карлице.

2. Прорачунати просечне параметре резултантне силе у зглобу кука (правац, нападни угао и интензитет резултантне силе нормализоване према телесној тежини), и то преоперативно (са евидентним поремећајем подударности зглобних површина) и постоперативно (налаз након троструком остеотомијом измењених биомеханичких услова оперисаног зглоба).

3. Одредити просечне параметре силе притиска у зглобу кука (максимални притисак директни и нормализован према телесној тежини, угао оријентације максималног притиска, индекс градијента силе притиска нормализован према телесној тежини) преоперативно и након примене троструке остеотомије карлице, и тиме биомеханички квантификовати ефекат троструке остеотомије на нивоу хијалине хрскавице зглобних површина зглоба кука.

4. Анализирати однос параметара резултантне силе и притиска на артикуларну хрскавицу зглоба кука према индикационим елементима (преоперативно мерљиви клинички и радиолошки параметри) и према прогностичким елементима (клинички и радиолошки параметри завршног постоперативног налаза). 


\section{МАТЕРИЈАЛ И МЕТОДЕ}

Модел истраживања представља кохортну студију.

Испитивана је група од 92 пацијента оперисаних троструком остеотомијом карлице у адолесцентном узрасту (од 10 до 20 година) у Институту за ортопедскохируршке болести "Бањица" у Београду, од увођења ове методе до 1.4.2011. године. На наведене пацијенте примењени су следећи селекциони критеријуми:

Критеријум за укључивање у студију:

1. Радиографски верификована неподударност зглобних површина, у једној од следеће три варијанте:

- Патолошка конфигурација ацетабулума (развојни поремећај кука),

- Патолошка конфигурација главе бутне кости (Пертесова болест),

- Патолошка конфигурација обе компоненте (постредукциона аваскуларна некроза).

Критеријуми за искључивање из студије:

1. Неадекватна радиографска документација (на радиограмима нису јасно видљиве све референтне тачке карлице и кукова неопходне у процесу мерења),

2. Облик главе фемура на радиограму у АП пројекцији такав да значајно одступа од округлог облика, што се квантификовало кроз испитивање циркуларности (параметра који говори о одступању овоида од кружнице, и израчунава се према формули: $\mathrm{C}=4 \pi \mathrm{P} / \mathrm{O}^{2}$, где је Р површина овоида у квадратним пикселима, а О обим овоида у пикселима). Као критеријум искључења одабрана је циркуларност мања од 0,95 јер је тада разлика између најмањег и највећег дијаметра овоидне главе бутне кости већа од $2 \mathrm{~mm}$,

3. Присуство луксације или сублуксације главе бутне кости

4. Праћење краће од годину дана. 
Након примене ових критеријума, формирана је испитивана група од 75 посматраних кукова код 60 пацијената.

Радиограм карлице са куковима омогућава увид у оба зглоба кука. То је пружило могућност да се на сваком радиограму осим испитиваног, анализира и наспрамни зглоб кука. Међу њима има здравих кукова, али и патолошких, лечених на различите начине. Стога су наспрамни кукови сврстани у једну од две следеће групе:

- Негативну контролну групу (здрави кукови) чинили су они наспрамни кукови који су испунили следећа четири критеријума :

○ Вибергов ЦЕ угао износи бар 25 степени;

○ Циркуларност главе износи најмање 0,98

○ Кукови никада нису били лечени

○ Одсуство симптома

- Позитивну контролну групу (промењени кукови) су чинили сви остали наспрамни кукови.

Код свих 75 радиографија обављена су два мерења: преоперативно и постоперативно. Код 50 случајева постојали су и контролни налази (са технички употребљивим контролним радиограмима) временски значајно удаљени од постоперативних (просечно 3,48+/-2,77 година, опсег од четири месеца до преко 11 година уз медијану од 2,87 година), те су и они анализирани. Инклузионе и ексклузионе критеријуме приликом трећег мерења задовољило је у испитиваној групи њих 44, у контролној групи здравих кукова 16, и у контролној групи промењених кукова 34 случаја.

На тај начин су формиране следеће групе случајева, анализираних кроз два, односно три поновљена мерења: (Табела 1)

Табела 1. Број случајева у анализираним групама, сва мерења

\begin{tabular}{|c|l|c|c|c|}
\hline \multicolumn{2}{|c|}{ Назив групе } & Мерење & Мерење & Мерење \\
\hline \multicolumn{2}{|c|}{ Број пацијената } & 1 & 2 & 3 \\
\hline Оперисани зглоб кука & Испитивана група & 75 & 75 & 50 \\
\hline \multirow{2}{*}{ Наспрамни зглоб кука } & Нггативна контролна група & 75 & 75 & 44 \\
\cline { 2 - 5 } & Позитивна контролна група & 56 & 20 & 16 \\
\hline
\end{tabular}


Анализом поновљених мерења неоперисаних кукова установљено је да су они у највећем проценту случајева задржали припадност истој подгрупи. Наиме, упоређењем преоперативних и постоперативних радиограма, 16 од 19 кукова $(84,2 \%)$ су остали у групи здравих, а 52 од 56 (92,9\%) су остали у групи промењених. Код оних кукова који имају и треће, завршно мерење, у категорији здравих је остало 10 од 16 кукова (62,5\%), а у категорији промењених остало је 31 од 34 кукова $(91,2 \%)$.

\section{Испитивана група}

У испитиваној групи 21 пацијент (28\%) је био мушког а 54 (72\%) женског пола. Rазвојни поремећај кука је био дијагностикован код 42 случаја (56\%), постредукциона аваскуларна некроза главе бутне кости у 19 сучајева $(25,3 \%)$ а Лег-Калве-Пертесова болест у 14 случајева (18,7\%). Код 17 случајева $(22,7 \%)$ није било никаквог претходног лечења, код њих 47 (62,6\%) предузимано је неоперативно лечење, док је у 11 случајева (14,7\%) примењивана једна или више метода оперативног лечења: Салтерова остеотомија карлице у пет случајева $(6,7 \%)$, крвава репозиција са Салтеровом остеотомијом у три случаја (4\%), спуштање великог трохантера у два случаја (2,7\%), Пембертонова ацетабулопластика у једном случају (1,3\%). Абревијациона остеотомија фемура је као додатни оперативни поступак урађена код шест од једанаест оперисаних пацијената.

У подгрупи кукова оболелих од Пертесове болести, у тренутку постављања индикација за оперативно лечење најчешће је констатована фаза кондензације (шест кукова, или 42,9\%), потом фаза фрагментације (четири кука, или 28,6\%). У подгрупи кукова са дијагостикованом постредукционом аваскуларном некрозом, примењена је Робер-Серенж класификација, и код скоро свих кукова (94,7\% случајева) уочен је капасто-валгусни тип деформитета, док је у једном случају уочен јајасто-варусни тип.

\section{Контролне групе}

Просечни Вибергов ЦЕ угао код негативне контролне групе (здрави кукови) је износио $32.98+/-7.73^{0}$ (опсег од $25-54^{0}$ ), а полупречник ротације зглоба кука 
3,78+/-2.07 cm (опсег од 2,12-10,05 cm, медијана 3,0 cm). Код позитивне контролне групе (промењени кукови) ЦЕ угао је био $17,11+/-8,37^{0}$ а полупречник ротације зглоба $4,08+/-1,79 \mathrm{~cm}$.

\section{Метод истраживања}

На све пацијенте који су оперисани троструком остеотомијом карлице у посматраном периоду примењен је тродимензионални математички модел зглоба кука базиран на нативној радиографији карлице са куковима у АП пројекцији, према методолошком упутству описаном у литератури ${ }^{150}$. Модел успоставља тродимензионални координатни систем са почетком у центру ротације зглоба кука такав да је вертикална $x$ оса позитивна навише, фронтална $y$ оса позитивна унапред, а сагитална $z$ оса позитивна пут медијално, и као улазне променљиве обухвата податак о полу и телесној тежини, као и сет лонгитудиналних и угаоних величина које је потребно презицно измерити на радиограмима. То су полупречник ротације у зглобу кука (r), половина растојања између центара ротације два кука (1/2), Вибергов ЦЕ угао, и четири дистанце од центра ротације зглоба кука: хоризонтална и вертикална удаљеност до референтне тачке абдукторног припоја на великом трохантеру (x, z), те хоризонтална и вертикална

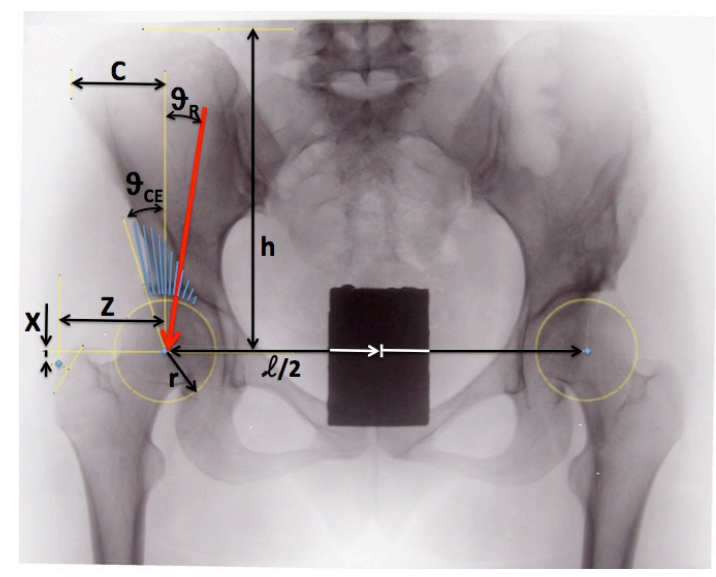

Слика 15: Улазне вредности модела удаљеност до најудаљених тачака на илијачној кристи $(\mathrm{C}, \mathrm{h})$. У ту сврху, сви валидни радиограми карлице са куковима су дигитализовани са резолуцијом од пет мегапиксела по радиограму, а мерења морфолошких параметара који представљају улазне променљиве за математички модел зглоба кука на њима обављена су коришћењем бесплатног рачунарског програма отвореног кода за биомедицинске дигиталне анализе ImageJ ${ }^{154}$. (Слика бр. 15)

Мерење са прикупљањем података обављено је за све пацијенте преоперативно и непосредно постоперативно (а за њих 50 је обављено и треће, 
завршно мерење) са постоперативним периодом праћења од најмање годину дана. Пошто примена тродимензионалног математичког модела зглоба кука подразумева мерење морфолошких улазних параметара илијачног крила и трохантерног масива у целини, као и одређивање центра ротације наспрамног зглоба кука, у преоперативној медицинској документацији је од свих технички употребљивих преоперативних снимака карлице са куковима обрађиван онај који је најкасније направљен, односно временски најближи датуму операције. Временски интервал између дана настанка радиограма и дана операције стога је био веома различит: од једног дана до године и пет месеци, са медијаном од 36 дана. Узраст пацијената у време операције износио је просечно 15 година и четири месеца уз медијану од 14 година и два месеца, и кретао се у интервалу од седам година и седам месеци до 32 године и 11 месеци.

Све линеарне измерене вредности су кориговане за процењено увеличање радиографских вредности у односу на реалне од 10\%. Добијене величине су потом унете у HIPSTRESS рачунарски програм, и помоћу њега су прорачунате излазне вредности које модел предвиђ $\mathrm{a}^{155}$.

Поред података неопходних за прорачун параметара силе и притиска у зглобу кука, прикупљени су и други релевантни медицински подаци у истим временским одредницама: анамнестички подаци (присуство иницијалних тегоба, врста претходног лечења), подаци добијени клиничким прегледом (телесна тежина, присуство инегалитета ногу, обим покрета зглоба кука, присуство гегања или храмања), класификациони системи за развојну фазу Лег-Калве-Пертесове болести (Хирохаши-Келер) ${ }^{156}$, а за постредукциони остеохондритис степен захваћености главе фемура (Робер-Серенж) и резидуални тип деформитета;

На основу измерених вредности, према тродимензионалном моделу зглоба кука израчунати су следећи биомеханички параметри:

- $\quad$ индекс величине резултантне силе нормализоване према телесној тежини - R/Wb (неименовани број);

- угао резултантне силе у зглобу кука у односу на вертикалну осу - $\theta-\mathrm{R}\left({ }^{0}\right)$;

- $\quad$ угао силе притиска (теоријска оријентација максималног притиска на ацетабуларну хрскавицу дистрибуираног без обзира на величину и 
оријентацију ацетабулума, односно као када би глава фемура била потпуно прекривена ацетабулумом)- $\theta$-pol $\left({ }^{0}\right)$;

- $\quad$ максимални притисак на артикуларну хрскавицу - Pmax $\left(10^{6} \mathrm{~Pa}\right)$;

- $\quad$ максимални притисак нормализован према телесној тежини - Pmax/Wb $\left(\mathrm{m}^{-3}\right)$;

- индекс градијента притиска на латералној ивици ацетабулума, нормализован према телесној тежини - $\mathrm{Gp} / \mathrm{Wb}\left(10^{3} \mathrm{~m}^{-3}\right)$, који је израчунат према следећој формули: $\mathrm{Gp} / \mathrm{Wb}=\left[\left(\mathrm{p}_{0} / \mathrm{r}\right) / \cos v \mathrm{~F}\right] / \mathrm{Wb}$, где је

$\mathrm{Gp}$ - Индекс градијента притиска;

$\mathrm{Wb}$ - телесна тежина $(\mathrm{N})$;

$\mathrm{p}_{0}$ - теоријски максимални притисак на површине $(\mathrm{Pa})$;

r - полупречник главе фемура (m);

vF - угао ацетабулнарне носеће површине (rad);

Материјал је статистички обрађен коришћењем стандардних дескриптивних статистичких показатеља ${ }^{157}$, уз напомену да је избор мере централне тенденције зависио од врсте скале података према Стивенсу (номинална, ординална, интервална или омерна), типа њихове расподеле и степена варирања.

Сагласност испитиваних података са нормалном расподелом је проверавана Колмогоров-Смирновљевим тестом ${ }^{157}$. У случајевима када је расподела података мерених интервалном или омерном скалом била блиска нормалној, а коефицијент варијације износио мање од 0,3 примењивана је средња вредност уз наведену стандардну девијацију. У осталим случајевима је поред средње вредности навођена и медијана.

Коришћене су следеће аналитичке статистичке методе ${ }^{157}$ : за поређење разлике код параметарских вредности коришћени су т-тест, једнофакторска и двофакторска анализа варијансе; за поређење разлике код непараметарских вредности за два низа података коришћени су $\chi^{2}$ тест, МекНемар тест и Вилкоксонов тест, а за више од два низа података Краскал-Волис анализа варијансе; за испитивање корелације коришћена је Пирсонова линеарна корелација, а у случају да подаци нису параметарски или нису нормално дистрибуирани, коришћена је Спирманова непараметарска корелација. Предикторна вредност варијабли испитивана је мултиваријантном логистичком 
регресијом. Примењени су стандардни критеријуми статистичке значајности од 0,05 и високе статистичке значајности од 0,01 . 


\section{РЕЗУЛТАТИ}

\section{Испитивана група}

МЕРЕњЕ 1 (ПРЕОПЕРАТИВНО)

Клинички налаз

Пре операције доминантан симптом оболелих кукова био је бол, присутан у 64 случаја (85,3\%). Поред тога, у 44 случаја уочен је и поремећај хода: гегање код осамнаест пацијената (25\%) и храмање код 26 пацијената $(34,7 \%)$.

Преоперативно измерени обими покрета у оболелом зглобу кука:

- $\quad$ флексија $115,6+/-20,07^{0}$

- екстензија $1,0+/-13,02^{0}$

- абдукција $28,7+/-10,88^{0}$

- адукција $19,5+/-7,65^{0}$

- спољашња ротација $28,1+/-11,39^{0}$

- унутрашња ротација $24,6+/-11,56^{0}$

У највећем броју случајева (54 кука, 72\%) није забележен клинички видљив инегалитет ногу пре операције.

\section{Радиографски налаз}

Измерени Вибергов ЦЕ угао је просечно износио $15,18+/-9,31^{0}$ (медијана $\left.15,6^{0}\right)$, и кретао се у интервалу од $-8-36,87^{0}$.

Просечна вредност полупречника ротације у зглобу кука износила је 3,68 +/1,5 cm (опсег од 1,31 - 11,08 cm, медијана 3,18 cm). Преоперативна просечна циркуларност у измереном материјалу је износила 0,985+/-0,022.

Анализирајући разлику у квалитету хода пре операције, установљена је статистички значајна разлика само код циркуларности зглоба кука: кукови код којих је ход био уредан имали су статистички значајно већу циркуларност $(0,995+/-0,006)$ него кукови где је установљено гегање $(0,979+/-0,031)$ или храмање $(0,978+/-0,024)(\mathrm{F}=5,199, \mathrm{p}<0,05)$. 
Када је у питању присуство или одсуство болних тегоба пре операције, ни код једног посматраног параметра није установљена статистички значајна разлика у дистрибуцији.

\section{Биомеханички параметри}

Преоперативни биомеханички параметри добијени применом математичког модела приказани су у Табели 2. Телесна маса у време преоперативног мерења износила је 48,2+/-15,9 kg.

Табела 2. Биомеханички параметри оперисаних зглобова кука - преоперативно мерење

\begin{tabular}{|l|c|c|}
\hline \multicolumn{1}{|c|}{ Параметар } & Опсег & $\overline{\mathrm{x}}+/-\mathrm{SD}$ \\
\hline $\mathrm{R} / \mathrm{Wb}(1)$ & $2,44-3,92$ & $3,24+/-0,35$ \\
\hline$\Theta-\mathrm{R}\left(^{0}\right)$ & $1,64-8,97$ & $5,72+/-1,69$ \\
\hline$\Theta-p o l\left(^{0}\right)$ & $16,65-79,42$ & $43,44+/-13,55$ \\
\hline $\mathrm{Pmax} / \mathrm{Wb}(1)$ & $487,9-43670,9$ & $5215,4+/-6366,46$ (медијана 4026,49) \\
\hline $\mathrm{Pmax}(\mathrm{MPa})$ & $0,15-17,4$ & $2,4+/-2,91$ (медијана 1,69) \\
\hline $\mathrm{Gp} / \mathrm{Wb}\left(10^{3} \mathrm{~m}^{-3}\right)$ & $-2,32-64215,49$ & $913,50+/-7416,94$ (медијана 4,67) \\
\hline
\end{tabular}

Статистички је испитивана разлика ових вредности у односу на дијагнозу, преоперативни квалитет хода и присуство болних тегоба пре операције. Код анализе у односу на дијагнозу, статистичка значајност установљена је само за нормализовану резултантну силу $(\mathrm{R} / \mathrm{Wb})$ и то између оболелих од развојног поремећаја кука $(3,29+/-0,35)$ и оболелих од Пертесове болести $(2,91+/-0,32)$ $(\mathrm{F}=4,283, \mathrm{p}<0,05)$. Остали преоперативни критеријуми нису довели до статистички значајних разлика. 
Анализирана је међусобна повезаност појединачних параметара, односно степен њиховог сличног, паралелног варирања унутар групе преоперативно испитиваних кукова. Уочене су следеће статистичке значајности:

- $\quad$ Узраст у време преоперативног мерења високо статистички високо значајно позитивно корелира са телесном тежином $(\mathrm{R}=0,573, \mathrm{p}<0,01)$.

- Полупречник ротације у посматраном зглобу кука статистички значајно корелира са Виберговим ЦЕ углом $(\mathrm{R}=-0,249, \mathrm{p}<0,05)$.

- Угао резултантне силе у зглобу кука показује статистички високо значајне негативне корелације са Виберговим ЦЕ углом $(\mathrm{R}=-0,376$, $\mathrm{p}<0,01)$ и са нормализованом максималном силом $(\mathrm{R}=-0,634, \mathrm{p}<0,01)$.

- Поред тога, нормализована максимална сила $(\mathrm{R} / \mathrm{Wb})$ има статистички високо значајне корелације са максималном силом притиска $(\mathrm{R}=0,463$, $\mathrm{p}<0,01)$ као и са нормализованом максималном силом притиска $(\mathrm{R}=0,385$, $\mathrm{p}<0,01)$, док значајне негативне корелације има са циркуларношћу $(\mathrm{R}=-$ $0,308, \mathrm{p}<0,05)$, а позитивне корелације са углом максималног притиска $(\mathrm{R}=0,3, \mathrm{p}<0,05)$.

- Вибергов ЦЕ угао статистички високо значајно негативно корелира са углом максималног притиска у зглобу кука $(\mathrm{R}=-0,96, \mathrm{p}<0,01)$

- $\quad$ И директни (Pmax) и нормализовани максимални притисак на артикуларну хрскавицу (Pmax/Wb) показују још и високо значајну корелацију и то негативну са Виберговим ЦЕ углом $\left(\mathrm{R}_{\mathrm{Pmax}}=-0,427\right.$, $\left.\mathrm{R}_{\mathrm{Pmax} / \mathrm{wb}}=-0,439, \mathrm{p}<0,01\right)$, и са полупречником ротације у зглобу кука $\left(\mathrm{R}_{\mathrm{Pmax}}=-0,505, \mathrm{R}_{\mathrm{Pmax} / \mathrm{Wb}}=-0,661, \mathrm{p}<0,01\right)$, а позитивну још и са углом максималног притиска $\left(\mathrm{R}_{\mathrm{Pmax}}=0,481, \mathrm{R}_{\mathrm{Pmax} / \mathrm{Wb}}=0,503, \mathrm{p}<0,01\right)$ као и међусобну корелацију $(\mathrm{R}=0,823, \mathrm{p}<0,01)$ 


\section{МЕРЕЊЕ 2 (ПОСТОПЕРАТИВНО)}

Анализирана је промена морфолошких и биомеханичких параметара кукова после троструке остеотомије карлице у односу на преоперативне вредности приказане у Табели 1. Резултати поређења два мерења приказани су у Табели 4.

Табела 4. Испитивана група - промене морфолошких и биомеханичких параметара након операције

\begin{tabular}{|c|c|c|c|}
\hline Параметар & $\begin{array}{c}\text { Мерење } 2 \\
\bar{x}+/-S D\end{array}$ & $\begin{array}{c}\text { Промена у односу на } \\
\text { мерење } 1(\Delta x, \%)\end{array}$ & $\begin{array}{c}\text { Статистичка } \\
\text { значајност разлике }\end{array}$ \\
\hline ЦЕ угао $\left(^{0}\right)$ & $\begin{array}{c}33,55+/-12,63 \\
\text { (медијана 33,45) }\end{array}$ & $17,85(114 \%)$ & $\mathrm{F}=231,392 ; \mathrm{p}<0,01$ \\
\hline $\mathrm{r}(\mathrm{cm})$ & $\begin{array}{c}3,93+/-1,78 \\
\text { (медијана 3,55) }\end{array}$ & $0,37(11,6 \%)$ & $F=5,969 ; p<0,05$ \\
\hline $\mathrm{R} / \mathrm{Wb}(1)$ & $3,14+/-0,37$ & $-0,107(3,3 \%)$ & $\mathrm{F}=11,326 ; \mathrm{p}<0,01$ \\
\hline$\Theta-R\left({ }^{0}\right)$ & $6,48+/-1,80$ & $0,88(15,3 \%)$ & $\mathrm{F}=18,947 ; \mathrm{p}<0,01$ \\
\hline$\Theta-p o l\left(\left(^{0}\right)\right.$ & $\begin{array}{c}16,59+/-11,92 \\
\text { (медијана 15,85) }\end{array}$ & $-27,59(63,5 \%)$ & $F=275,289 ; p<0,01$ \\
\hline $\mathrm{Pmax} / \mathrm{Wb}(1)$ & $\begin{array}{l}2748,31+/-1766,16 \\
(\text { медијана } 1776,75)\end{array}$ & $-2249,74(55,9 \%)$ & $\mathrm{F}=9,157 ; \mathrm{p}<0,01$ \\
\hline Pmax (MPa) & $\begin{array}{c}1,01+/-0,7 \\
\text { (медијана } 0,91)\end{array}$ & $-0,78(46,2 \%)$ & $F=26,693 ; p<0,01$ \\
\hline $\mathrm{Gp} / \mathrm{Wb}\left(10^{3} \mathrm{~m}^{-3}\right) *$ & $\begin{array}{c}-0,25+/-5,2 \\
\text { (медијана }-0,48)\end{array}$ & $e^{8,02}(67,1 \%)^{*}$ & $z=-6,4573 ; p<0,01$ \\
\hline
\end{tabular}

* за потребе поређења у процентима, податак је трансформисан тако да се добила линеарна скала. 


\section{МЕРЕЊЕ 3 (ЗАВРШНО)}

Код 44 случаја је поред преоперативног и постоперативног обављено и треће, завршно мерење. Просечне вредности морфолошких и биомеханичких параметара добијених у тим поновљеним мерењима приказани су Табели 5. Урађена је и статистичка анализа, и појачано су одштампане оне вредности које се од осталих статистички значајно разликују, а ниво значајности је означен звездицама $\left({ }^{*}\right.$-p $<0,05 ; * *$ - $\left.<<0,01\right)$.

Табела 5. Морфолошки и биомеханички параметри оперисаних зглобова кука мерење 1,2 и 3

\begin{tabular}{|c|c|c|c|}
\hline Параметар & $\begin{array}{c}\text { Мерење } 1 \\
\bar{x}+/-S D \\
\end{array}$ & $\begin{array}{c}\text { Мерење } 2 \\
\bar{x}+/-S D \\
\end{array}$ & $\begin{array}{c}\text { Мерење } 3 \\
\bar{x}+/-S D \\
\end{array}$ \\
\hline TM (kg) & $46,17+/-15,34(* *)$ & $49,221+/-15,22(* *)$ & $56,25+/-12,67(* *)$ \\
\hline ЦЕ угао $\left(^{0}\right)$ & $\begin{array}{l}\text { 15,18+/-9,46 (**) } \\
\text { (медијана 16,34) }\end{array}$ & $\begin{array}{c}34,44+/-13,16 \\
\text { (медијана } 36,1) \\
\end{array}$ & $\begin{array}{c}34,85+/-13.75 \\
\text { (медијана } 35,59) \\
\end{array}$ \\
\hline $\mathrm{r}(\mathrm{cm})$ & $3,69+/-1,15(* *)$ & $\begin{array}{l}3,96+/-1,81(* *) \\
\text { (медијана } 3,19)\end{array}$ & $\begin{array}{c}3,8+/-1,25(* *) \\
(\text { медијана } 3,48)\end{array}$ \\
\hline $\mathrm{R} / \mathrm{Wb}(1)$ & $3,26+/-0,34$ & $\mathbf{3 , 1 + / - 0 , 3 7 ( * * )}$ & $3,29+/-0,46$ \\
\hline$\Theta-\mathrm{R}\left({ }^{0}\right)$ & $5,56+/-1,63$ & $6,69+/-1,82(* *)$ & $5,49+/-1,72$ \\
\hline$\Theta-\operatorname{pol}\left(\left(^{0}\right)\right.$ & $44,08+/-13,55(* *)$ & $\begin{array}{c}15,86+/-12,18 \\
\text { (медијана 11,02) }\end{array}$ & $\begin{array}{c}18,08+/-14,06 \\
\text { (медијана 16,62) }\end{array}$ \\
\hline $\mathrm{Pmax} / \mathrm{Wb}(1)$ & $\begin{array}{c}5473,08+/-6489,91(* *) \\
(\text { медијана 4229,45) }\end{array}$ & $\begin{array}{c}2026.82+/-1415.41 \\
\text { (медијана 1852,26) }\end{array}$ & $\begin{array}{r}2099.85+/-1377.34 \\
\text { (медијана 1673,64) }\end{array}$ \\
\hline $\operatorname{Pmax}(\mathrm{MPa})$ & \begin{tabular}{|c|}
$\begin{array}{c}2,4+/-2,5 \\
(* * *) \\
\text { медијана 1,7) }\end{array}$ \\
\end{tabular} & $\begin{array}{c}1,0+/-0,7 \\
\text { (медијана 0,9) }\end{array}$ & $\begin{array}{c}1,1+/-0,7 \\
\text { (медијана 0,9) } \\
\end{array}$ \\
\hline $\mathrm{Gp} / \mathrm{Wb}\left(10^{3} \mathrm{~m}^{-3}\right)$ & $\begin{array}{c}23,59+/-45,15(* *) \\
\text { (медијана 8,48) }\end{array}$ & $\begin{array}{c}-0,12+/-6,53 \\
\text { (медијана }-0,07)\end{array}$ & $\begin{array}{c}0,18+/-4,23 \\
\text { (медијана }-1,06)\end{array}$ \\
\hline
\end{tabular}




\section{ПОРЕЪЕЊЕ МЕРЕЊА 1 И 3}

\section{Анатомски налаз}

Статистички је анализирано и да ли је након операције дошло до промене релативне дужине оперисане ноге мерено у односу на наспрамну, неоперисану ногу. Преоперативно је испитивана нога била краћа од наспрамне за просечно 0,21+/-1,06 cm, и та се разлика након операције смањила на 0,12+/-0,94 cm, без статистичке значајности $(t=1,050 ; p>0.05)$. Како би се проверио евентуални утицај патолошких промена наспрамних кукова, засебно је анализирана и подгрупа оперисаних кукова чији су наспрамни кукови у оба мерења били здрави. Статистички значајна разлика такође није установљена $(\mathrm{t}=0,1331 ; \mathrm{p}>0,05)$.

Анализирана је и циркуларност главе фемура пре и после операције. Преоперативно је циркуларност износила 0,985, а постоперативно 0,987. Статистичка разлика није установљена $(\mathrm{t}=1,021 ; \mathrm{p}>0,05)$

\section{Функционални налаз}

Вршена је анализа вредности обима покрета оперисаног зглоба кука пре и после операције. Резултати су приказани на Графикону 1.

Графикон 1. Релативне вредности просечног обима покрета у испитиваној групи (проценат од физиолошког обима покрета): преоперативни и завршни налаз

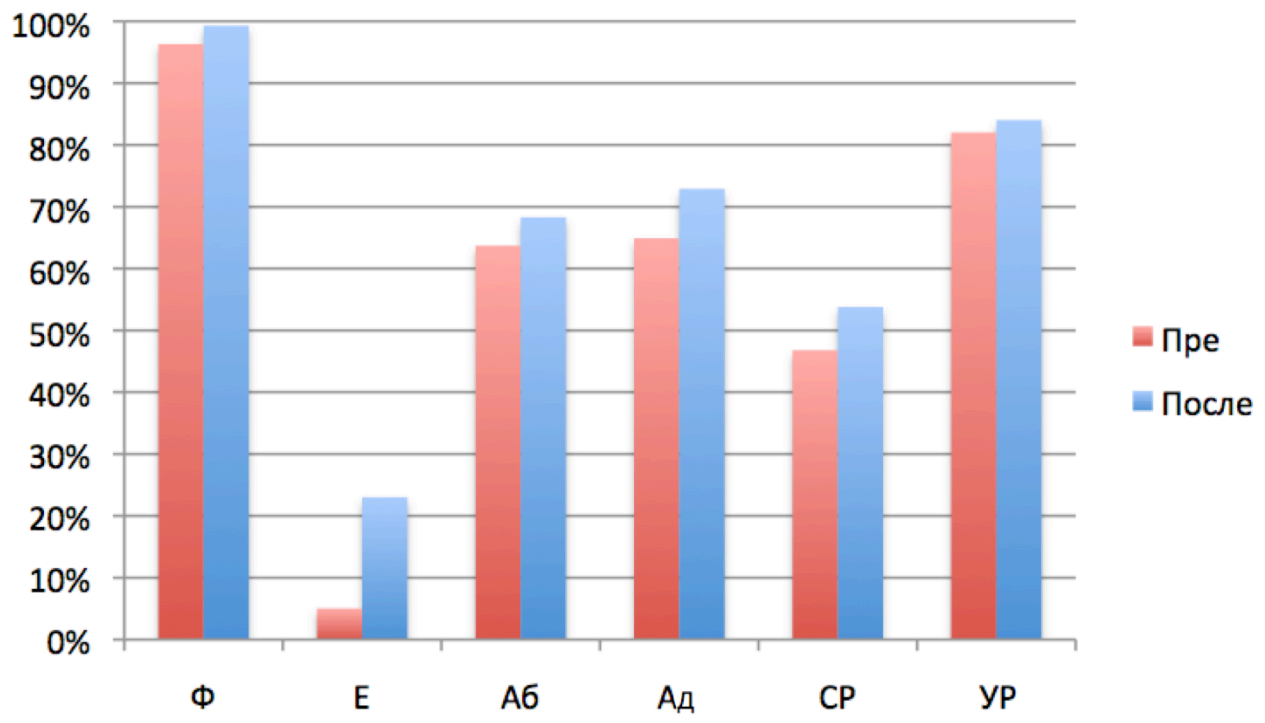


Статистичка разлика у покретима испитиване групе кукова пре и после операције уочена је само за покрете екстензије и спољашње ротације, мада је величина те разлике клинички занемарљива: 3,6 степени код екстензије и 4,2 степена код спољашње ротације. Уочена је и корелација преоперативне са постопративном величином код свих категорија покрета: за покрете екстензије и спољашње ротације на високо значајном нивоу, док је код осталих категорија покрета била потврђена на стандардном нивоу значајности.

Квалитет хода посматраном ногом је такође статистички анализиран, а податак је прикупљен за 71 (94,7\%) пацијента. Пре операције је гегало 17 (23,9\%) пацијената, храмање је примећено код њих 26 (36,7\%), док је 28 пацијената $(39,4 \%)$ имало нормалан ход. Након операције гегање је било присутно код свега четири пацијента $(5,6 \%)$ и храмање код осам $(11,3 \%)$, док је њих $59(83,1 \%)$ имало неупадљив ход. Применом МекНемар теста потврђена је висока статистичка значајност уоченог смањења присуства и гегања $(\mathrm{McNemar}, \# \mathrm{BA}=3, \# \mathrm{AB}=16$, $\mathrm{p}<0,01)$ и храмања $(\mathrm{McNemar}, \# \mathrm{BA}=3, \# \mathrm{AB}=21, \mathrm{p}<0,01)$. 


\section{Контролне групе}

\section{MEPEњЕ 1}

У Табели 6 приказане су вредности биомеханичких параметара које модел зглоба кука предвиђа за негативну (здрави кукови) и позитивну контролну групу (промењени кукови) на основу података добијених на првом мерењу.

Табела 6. Биомеханички параметри негативне и позитивне контролне групе мерење 1

\begin{tabular}{|c|c|c|c|c|}
\hline \multirow[b]{2}{*}{ Параметар } & \multicolumn{2}{|c|}{$\begin{array}{c}\text { Негативна контролна } \\
\text { група }\end{array}$} & \multirow{2}{*}{$\begin{array}{c}\begin{array}{c}\text { Позитивна } \\
\text { контролна група }\end{array} \\
\overline{\mathrm{x}}+/ \text {-SD }\end{array}$} & \multirow{2}{*}{$\begin{array}{c}\text { Статистичка } \\
\text { значајност } \\
\text { разлике }\end{array}$} \\
\hline & Опсег & $\overline{\mathrm{x}}+/-\mathrm{SD}$ & & \\
\hline $\mathrm{R} / \mathrm{Wb}(1)$ & $2,50-3,80$ & $2,94+/-0,32$ & $3,22+/-0,32$ & $\begin{array}{c}\mathrm{Z}=-3.314 \\
\mathrm{p}<0,01\end{array}$ \\
\hline$\Theta-\mathrm{R}\left({ }^{0}\right)$ & $1,86-9,65$ & $5,69+/-1,99$ & $5,96+/-1,4$ & $\begin{array}{c}\mathrm{Z}=-0.05 \\
\mathrm{p}>0,05\end{array}$ \\
\hline$\Theta-\operatorname{pol}\left(\left(^{0}\right)\right.$ & $1,55-33,07$ & $\begin{array}{c}19,83+/-7,88 \\
\text { (медијана 20,39) }\end{array}$ & $39,52+/-11,85$ & $\begin{array}{c}Z=-5.19 \\
p<0,01\end{array}$ \\
\hline $\mathrm{Pmax} / \mathrm{Wb}(1)$ & $180.71-3843.58$ & $\begin{array}{l}2148,62+/-1115,92 \\
(\text { медијана 2216,58) }\end{array}$ & $\begin{array}{l}3717,17+/-2468,28 \\
(\text { медијана } 3388,41)\end{array}$ & $\begin{array}{c}\mathrm{Z}=-2.301 \\
\mathrm{p}<0,05\end{array}$ \\
\hline Pmax (MPa) & $0,05-1,64$ & $\begin{array}{c}0,82+/-0,43 \\
\text { (медијана 0,83) }\end{array}$ & $\begin{array}{c}1,74+/-1,18 \\
\text { (медијана } 1,58)\end{array}$ & $\begin{array}{c}\mathrm{Z}=-3.363 \\
\mathrm{p}<0,01\end{array}$ \\
\hline $\mathrm{Gp} / \mathrm{Wb}\left(10^{3} \mathrm{~m}^{-3}\right)$ & $-4.77-1.05$ & $\begin{array}{c}-1,24+/-1,54 \\
\text { (медијана -1,02) }\end{array}$ & $\begin{array}{c}11,84+/-21,01 \\
\text { (медијана 3,49) }\end{array}$ & $\mathrm{W}=247, \mathrm{p}<0,01$ \\
\hline
\end{tabular}

Статистичка анализа је показала да се скоро све излазне вредности математичког модела код две подгрупе неоперисаних кукова статистички разликују. Изузетак је угао резултантне силе $(\Theta-R)$. 


\section{MEPEњЕ 2}

Шеснаест случајева је припадало негативној контролној групи (здрави кукови) и на првом и на другом мерењу. Анализиране су разлике у морфолошким и биомеханичким параметрима између првог и поновљеног мерења. (Табела 7)

Табела 7. Морфолошки и биомеханички параметри негативне контролне груперазлика између мерења 1 и мерења 2

\begin{tabular}{|c|c|c|c|}
\hline Параметар & $\begin{array}{c}\text { Мерење } 1 \\
\bar{x}+/-S D \\
\end{array}$ & $\begin{array}{c}\text { Мерење } 2 \\
\bar{x}+/-S D\end{array}$ & $\begin{array}{c}\text { Статистичка } \\
\text { значајност разлике }\end{array}$ \\
\hline Телесна маса $(\mathrm{kg})$ & $42,59+/-13,85$ & $46,84+/-14,37$ & $\mathrm{t}=-4,115 ; \mathrm{p}<0,01$ \\
\hline ЦЕ угао $\left(^{0}\right)$ & $33,9+/-8,04$ & $34,75+/-5,9$ & $F=0,366 ; p>0,05$ \\
\hline $\mathrm{r}(\mathrm{cm})$ & $3,52+/-1,52$ & $3,34+/-1,69$ & $\mathrm{~F}=1,42 ; \mathrm{p}>0,05$ \\
\hline $\mathrm{R} / \mathrm{Wb}(1)$ & $2,96+/-0,35$ & $2,82+/-0,3$ & $\mathrm{~F}=17,392 ; \mathrm{p}<0,01$ \\
\hline$\Theta-\mathrm{R}\left({ }^{0}\right)$ & $\begin{array}{c}5,43+/-1,9 \\
\text { (медијана 5,86) }\end{array}$ & $5,67+/-1,93$ & $\mathrm{~F}=0,810 ; \mathrm{p}>0,05$ \\
\hline$\Theta-\operatorname{pol}\left(\left(^{0}\right)\right.$ & $\begin{array}{c}19,41+/-8,46 \\
\text { (медијана 20,84) }\end{array}$ & $\begin{array}{c}17,46+/-6,13 \\
\text { (медијана } 16,72 \text { ) }\end{array}$ & $\mathrm{F}=1,533 ; \mathrm{p}>0,05$ \\
\hline $\mathrm{Pmax} / \mathrm{Wb}(1)$ & $2154,34+/-1056,06$ & $\begin{array}{c}2171,36+/-926,43 \\
\text { (медијана } 2124,15)\end{array}$ & $\mathrm{F}=0,018 ; \mathrm{p}>0,05$ \\
\hline Pmax (MPa) & $\begin{array}{c}0,82+/-0,39 \\
\text { (медијана } 0,76)\end{array}$ & $\begin{array}{c}0,92+/-0,33 \\
\text { (медијана 1,02) }\end{array}$ & $F=2,265 ; p>0,05$ \\
\hline $\mathrm{Gp} / \mathrm{Wb}\left(10^{3} \mathrm{~m}^{-3}\right)$ & $\begin{array}{c}-1,38+/-1,63 \\
\text { (медијана }-1,04)\end{array}$ & $\begin{array}{c}-1,91+/-1,58 \\
\text { (медијана }-1.49 \text { ) }\end{array}$ & $z=-1,5771 p>0,05$ \\
\hline
\end{tabular}




\section{Поређење испитиване и контролне групе}

\section{MEPEњЕ 1}

На првом (односно за оперисане кукове преоперативном) мерењу уочена је група од 19 пацијената чији је један кук припадао испитиваној групи, а наспрамни кук припадао негативној контролној групи, коју чине здрави кукови. Код њих је урађено поређење морфолошких и биомеханичких параметара два кука. Испитивана група је имала знатно слабију натковљеност (ЦЕ угао $18,85+/-9,9^{0}$ у односу на $32,98+/-7,73^{0}$ у групи здравих, $\left.\mathrm{F}=34,965, \mathrm{p}<0,01\right)$ и неповољнију

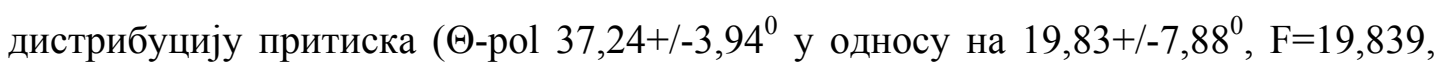
$\mathrm{p}<0,01)$, и то нарочито близу латералне ивице ацетабулума (Gp/ $\mathrm{Wb} 32,38+/-72,19$, медијана 1,96 , у односу на $-1,15+/-1,55$ и медијану од -0,88). Остали морфолошки и биомеханички параметри (r, R/Wb, $\Theta-\mathrm{R}, \mathrm{Pmax} / \mathrm{Wb}$ и Pmax) нису показали статистичку разлику.

\section{Предиктори оперативног резултата}

Логистичком регресијом је процењивана предикторна вредност преоперативно мерених варијабли за завршни анатомски налаз (мерен Виберговим ЦЕ углом) и функционални налаз (мерен присуством тегоба и квалитетом хода). Од 75 посматраних случајева, посматране варијабле су биле комплетно присутне код њих 71. Дистрибуција завршног налаза је следећа: код 42 случаја $(59,1 \%)$ оба завршна налаза су повољна (Вибергов ЦЕ угао од бар 25 степени, нема тегоба ни поремећаја хода); код 17 кукова $(23,9 \%)$ само функционални завршни налаз је повољан; код преосталих 12 кукова (17\%) повољан је само анатомски исход, док потпуно неповољан исход није забележен.

Резултати логистичке регресије показују да се као статистички високо значајан предиктор показао преоперативно измерени Вибергов ЦЕ угао (Wald $=10,458 ; \mathrm{p}<0,01$ ), док су веома близу границе статистичке значајности преоперативни радијус ротације у зглобу кука (Wald $=3,782 ; \mathrm{p}=0,052)$, преоперативна нормализована резултантна сила у зглобу кука (Wald=3,757; $\mathrm{p}=0,053)$ и постоперативни нормализовани индекс градијента притиска (Wald=3,562, p=0,059). (Табела 8) 
Када је у питању предикција завршног функционалног налаза, једини статистички значајан предиктор је преоперативни квалитет хода (Wald=4,82; $\mathrm{p}<0,05)$, уз напомену да је преоперативни ЦЕ угао близу границе статистичке значајности (Wald=3,798; p=0,051) уколико се посматра издвојено, али ту статистичку значајност гранично задовољава уколико се анализира заједно са преоперативним квалитетом хода (Wald $=3,842 ; \mathrm{p}=0,05)$. (Табела 9)

Табела 8. Предиктори завршног анатомског налаза

\begin{tabular}{|c|c|c|c|c|c|c|}
\hline Параметар & Б & $\begin{array}{c}\text { Стандардна } \\
\text { грешка }\end{array}$ & $\begin{array}{c}\text { Валдова } \\
\text { статистика }\end{array}$ & $\begin{array}{l}\text { Степен } \\
\text { слободе }\end{array}$ & $\begin{array}{c}\text { Статистичка } \\
\text { значајност }\end{array}$ & $\begin{array}{c}\text { Укрштени } \\
\text { однос }\end{array}$ \\
\hline ЦЕ & $-0,142$ & 0,044 & 10,458 & 1 & 0,001 & 0,87 \\
\hline \multirow{4}{*}{$\begin{array}{l}\mathrm{r}_{1} \\
\mathrm{R} / \mathrm{Wb}_{1} \\
\mathrm{Gp} / \mathrm{Wb}_{2} \\
\text { Константа }\end{array}$} & 47,556 & 24,455 & 3,782 & 1 & 0,052 & 0,88 \\
\hline & $-2,113$ & 1,090 & 3,757 & 1 & 0,053 & 0,12 \\
\hline & $-0,368$ & 0,195 & 3,562 & 1 & 0,059 & 0,69 \\
\hline & 7,782 & 3,654 & 4,536 & 1 & 0,033 & 23950,98 \\
\hline
\end{tabular}

$\mathrm{r}_{1}$ - преоперативни радијус ротације у зглобу кука

Табела 9. Предиктори завршног функционалног налаза

\begin{tabular}{|c|c|c|c|c|c|c|}
\hline Параметар & Б & $\begin{array}{l}\text { Стандардна } \\
\text { грешка }\end{array}$ & $\begin{array}{c}\text { Валдова } \\
\text { статистика }\end{array}$ & $\begin{array}{c}\text { Степен } \\
\text { слободе }\end{array}$ & $\begin{array}{c}\text { Статистичка } \\
\text { значајност }\end{array}$ & $\begin{array}{c}\text { Укрштени } \\
\text { однос }\end{array}$ \\
\hline ЦЕ 1 угао & 0,081 & 0,041 & 3,842 & 1 & 0,050 & 1,08 \\
\hline$\Phi_{1}$ & 0,967 & 0,440 & 4,820 & 1 & 0,028 & 2,63 \\
\hline Константа & 7,782 & 3,654 & 4,536 & 1 & 0,033 & 2395,98 \\
\hline
\end{tabular}

$\Phi_{1}$ - функционални налаз пре операције 


\section{ДИСКУСИЈА}

Испитивање биомеханичких својстава зглоба кука и њиховог утицаја на исход лечења различитих деформитета применом читаве палете оперативних поступака није новог датума. Мотиви за овај правац истраживања су многоструки: постоје клинички докази да сила која на ацетабуларну хрскавицу делује предуго или превеликим интензитетом, доводи до дегенеративних промена и појаве болова у зглобу. Даље, лабораторијска мерења силе на кадаверичним моделима указала су да остваривање физиолошке механике зглоба кука побољшава његову функцију и успорава дегенеративне промене ${ }^{76}$.

Савремени интерес за однос сила које постоје у зглобу кука и његове морфологије пружа бољу могућност разумевања етиологије патолошких процеса који га захватају, и већу ефикасност њиховог ортопедског лечења. Ово се нарочито односи на развојни поремећај кука и остеоартрозу, али и на друге поремећаје зглоба кука. Ова два патолошка стања су значајно повезана: доказано је да је присуство дисплазије зглоба кука значајан етиолошки фактор настанка коксартрозе услед смањења носеће површине и повећања притиска на артикуларну хрскавицу ${ }^{51,91,158,159,160,161,162,163,164,165,166}$. Код око 50\% пацијената са дисплазијом зглоба кука коксартроза се може очекивати пре 60. године ${ }^{167}$. Ипак, валидна предикција појаве коксартрозе код диспластичних кукова само на основу морфолошке процене величине (интензитета) дисплазије није изводљива ${ }^{138}$. Разлог је у томе што некада и мале вредности Виберговог ЦЕ угла ${ }^{168}$ (угао мањи од 25 степени представља критеријум за постављање дијагнозе дисплазије зглоба кука) не морају нужно бити праћене и великим интензитетом силе притиска на зглобну хрскавицу, већ то зависи од правца вектора резултантне силе у том зглобу ${ }^{79}$.

\section{Квалитет мерених и прорачунатих података}

Карактеристике мерења имају пресудан утицај на интерпретацију и употребну вредност мерењем добијених резултата. У том смислу, неопходно је да подаци које предвиђа тродимензионални математички модел зглоба кука задовоље следеће критеријуме: 


\section{Поузданост}

Критеријум поузданости (објективности, односно поновљивости) резултата у овом истраживању је испитана путем поновљених мерења и анализе кукова који припадају негативној контролној групи, односно здравих кукова. Резултати, сумирани у Табели 6 , указују да се телесна маса (за 9,1\%) и величина резултантне силе нормализоване према телесној тежини (за 4,8\%) статистички високо значајно разликују у поновљеним мерењима. Овакав налаз се објашњава већом вероватноћом гојења пацијената у условима ограничене могућности кретања у постоперативном периоду, као и отежаним заузимањем правилног положаја ногу приликом снимања радиограма. Иста тенденција се може видети и на оперисаним куковима на другом мерењу. (Табела 5)

Да би се при евалуацији поновљивости резултата избегао наведени утицај, испитана је Краскал-Волис непараметарска једносмерна анализа варијансе групе од 10 кукова који су на сва три мерења припадали негативној контролној групи. Ни код једног параметра параметара математичког модела није уочена статистички значајна разлика на три поновљена мерења. (Табела 10)

Табела 10. Критеријум објективности метода - мерења 1, 2 и 3

\begin{tabular}{|c|c|c|}
\hline Параметар & Вредност теста & Статистички резултат \\
\hline $\mathrm{R} / \mathrm{Wb}(1)$ & $\mathrm{F}=1,76$ & $\mathrm{p}>0,05$ \\
\hline$\Theta-\mathrm{R}\left({ }^{0}\right)$ & $\mathrm{F}=1,363$ & $\mathrm{p}>0,05$ \\
\hline$\Theta-\mathrm{pol}\left({ }^{0}\right)$ & $\mathrm{F}=0,766$ & $\mathrm{p}>0,05$ \\
\hline $\mathrm{Pmax} / \mathrm{Wb}(1)$ & $\mathrm{F}=3,22$ & $\mathrm{p}>0,05$ \\
\hline $\mathrm{Pmax}(\mathrm{MPa})$ & $\mathrm{F}=1,312$ & $\mathrm{p}>0,05$ \\
\hline $\mathrm{Gp} / \mathrm{Wb}\left(10^{3} \mathrm{~m}^{-3}\right)$ & $\mathrm{F}=2,282$ & $\mathrm{p}>0,05$ \\
\hline
\end{tabular}

Закључује се да је критеријум поузданости испуњен. 


\section{Валидност}

Валидност, или ваљаност модела (показатељ да модел заиста квантификује величине које је предвиђено да квантификује) се манифестује на следеће начине:

(a) успешним разликовањем негативне од позитивне контролне групе. Контралатерални кукови су стандардним ортопедским критеријумима разврстани на негативну (здрави кукови) и позитивну контролну групу (промењени кукови), и просечне вредости биомеханичких параметара које модел предвиђа разликују се високо статистички значајно, у корист здравих кукова. Код њих се описује мања интензитет нормализоване резултантне силе, мањи угао максималног притиска у зглобу, мањи интензитети максималног и нормализованог максималног притиска на зглобне површине, као и негативан нормализовани индекс градијента силе притиска на латералној ивици ацетабулума. (Табела 6)

(б) поређење испитиване и негативне контролне групе, описане у резултатима, такође указује на статистички високе значајности разлика у корист здравих кукова.

(в) поређењем њиме добијених биомеханичких параметара налазима других истраживача $^{20,99}$ уочава се исти ред величине и конзистентне вредности максималног притиска у зглобу кука, као инормализовних вредности резултантне силе и силе притиска.

Закључује се да је испуњен критеријум валидности

\section{Дискриминативност}

Дискриминативност (сензитивност и специфичност) модела представља његову способност да добро разликује модалитете посматране величине у узорку на који се примењује. Пошто је тродимензионаолни математички модел зглоба кука усмерен на анализу дистрибуције силе на зглобну површину, и у литератури се наводи хипотеза да је нормализовани индекс градијента притиска на латералној ивици ацетабулума $(\mathrm{Gp} / \mathrm{Wb})$ биомеханички параметар који најбоље описује последице те силе ${ }^{99}$, испитали смо дискриминативност овог параметра за дисплазију зглоба кука у односу на стандардни радиолошким критеријумом недовољне покривености зглоба, Вибергов ЦЕ угао мањи од 25 степени. 
Табела 11. Нормализовани индекс градијента притиска на мерењу 2 као фактор ризика за исход Виберговог ЦЕ угла на мерењу 3- испитивана група

\begin{tabular}{|c|c|c|c|}
\hline \multirow{2}{*}{$\mathrm{Gp} / \mathrm{Wb}>0$} & \multicolumn{2}{|c|}{ ЦЕ угао $<25^{0}$ на завршном мерењу } & \multirow{2}{*}{ Укупно } \\
\cline { 2 - 4 } & + & 14 & 21 \\
\hline+ & 5 & 21 & 26 \\
\hline- & 12 & 35 & 47 \\
\hline
\end{tabular}

Постоперативно позитиван $\mathrm{Gp} / \mathrm{Wb}$ код испитиване групе носи релативни ризик од 1,73 , као и 2,1 пута већу шансу за погоршање наткровљености на завршном мерењу

Закључује се да су критеријуми сензитивности и специфичности валидности испуњени.

\section{Прецизност}

Познато је да, осим пребројавања, свако квантификовање било које физичке величине односно упоређивање непознате величине са мерном скалом укључује појаву системске, односно апсолутне грешке. У том смислу, потребно је размотрити неколико важних аспеката њиховог генерисања, и проценити максималну очекивану величину тиме настале грешке.

\section{Прочес дигитализачије}

Сви радиограми су фотографисани на негатоскопу помоћу истог дигиталног фотоапарата на сталку причвршћеном за подлогу, тако да је растојање, резолуција, режим рада апарата и осветљење било константно током читавог процеса. 


\section{Прочес мерења на дигитализованом радиограму}

У свакодневној ортопедској пракси, мерења релевантних углова и дистанци на радиограмима се мануелно обављају милиметарским лењирима. Апсолутна грешка која притом настаје износи $0,5 \mathrm{~mm}$. Да бисмо одредили колику грешку можемо очекивати у индиректно одређеним, односно прорачунатим биомеханичким излазним параметрима математичког модела зглоба кука, послужили смо се нумеричком методом: најпре смо за сваку улазну величину у модел (телесна маса и све мерене величине на радиограмима детаљно описане у поглављу Материјал и метод), пробним варирањем за износ апсолутне грешке утврдили да ли мења сваки од шест излазних параметара модела $(\mathrm{R} / \mathrm{Wb}, \Theta-\mathrm{R}, \Theta-$ pol, Pmax/Wb, Pmax, Gp/Wb), у ком правцу и и за који износ. Потом смо за сваки од тих параметара прорачунали која комбинација варирања улазних величина максимално повећава највећу израчунату вредност у испитиваној групи. Аналогну радњу смо применили и на најмању вредност излазних параметара у испитиваној групи. Тако добијене промене биомеханичких параметара (излазних вредности математичког модела) се налазе у опсегу од 1,07-13,68\%.

Наведени резултат важи за аналогно мерење лењиром. Како би додатно умањили апсолутну грешку, радиограми су дигитализовани са резолуцијом таквом да је један центиметар био представљен помоћу 67 пиксела. Апсолутна грешка при коришћењу рачунарских мерних алата у мерењу дистанци на екрану износи један пиксел, односно 3,35 пута је мања од оне настале аналогним мерењем. Дакле, у нашим подацима грешке услед мерења не прелазе 4,1\%. Према истраживању Троелсена и сар. варијације у мерењу Виберговог ЦЕ угла при поновљеним мерењима се крећу од 5,6-6 степени уз интервал поверења од $95 \% .{ }^{169,170}$ Наша процењена грешка настала у процесу мерења на дигитализованим радиограмима је значајно мања. 


\section{Критеријум за процену сферичности кукова}

Параметар којим се на радиограму описивало одступање пројекције феморалне зглобне површине од идеалне кружнице је циркуларност, која за идеалну кружницу износи 1,00. Просечна циркуларност измерена у овом истраживању у испитиваној групи износила је пре операције $0,985+/-0,022$, без значајних промена на поновљеним мерењима. Математички модел је примењен само на кукове који имају циркуларност 0,95 и већу, што уз резолуцију дигитализације и прецизност примене дигиталних алата за мерење циркуларности и дистанце на екрану доводи до одступања центра главе фемура (дефинисаног тежиштем највећег овоида уписаног у контуру главе фемура) и центра ротације у зглобу кука (дефинисног центром кружнице чији се одсечак поклапа са површином контуре главе фемура која у физиолошком опсегу покрета долази у контакт са ацетабулумом) не већег од два милиметра, колико се очекује и у физиолошким условима услед еластичне деформације зглобних хрскавица ${ }^{122}$. Закључује се да је наведени критеријум валидно обухватио сферичне кукове.

\section{Репрезентативност статичког једноножног ослонца}

Тродимензионални математички модел зглоба кука анализира параметре силе у статичком једноножном ослонцу. Резултати овакве анализе ипак имају шири значај, односно релевантност за просечну покретљивост током свакодневних људских активности, што потврђују и аутори метода поређењем резултата са налазима мерења помоћу интраартикуларних сензора ${ }^{171}$. Поред тога, постоје и следећи аргументи:

- $\quad$ У нашем материјалу већина контралатералних кукова такође није била здрава. Истраживања говоре да деформитети контралатералног зглоба кука немају значајан утицај на расподелу сила у анализираном зглобу ${ }^{86}$. Ово запажање је омогућило да се посредно испитивање деформисаних глава фемура, на пример код Пертесове болести, испитивањем контралатералног здравог зглоба уколико су кукови пре почетка те болести били симетрични ${ }^{20}$. 
- $\quad$ Модел предвиђа превелику носећу површину зглоба кука, јер у њу укључује и ацетабуларну јаму (fossa acetabuli) испуњену масним ткивом (pulvinar). Међутим, сила притиска у овом региону и није значајног интензитета, и у присуству интактног лабрума масно ткиво је у стању да је бар делимично дистрибуира, тако да и не настаје значајна грешка ${ }^{79}$.

- Правац резултантне силе се кроз циклус хода мења на карактеристичан начин: трајекторија резултантне силе на ацетабуларној хрскавици описује приближно потковичасту путању која лежи у постеромедијалном делу ацетабулума. Код диспластичних кукова путања је у целини ближа латералној ивици ацетабулума и померена нешто унапред, али је то нарочито изражено у средњем делу потковице, односно током фазе једноножног ослонца при ходу, када резултантна сила која се може детектовати у зглобу кука при нормалном износи око 250-350\% телесне тежине ${ }^{172,173,174}$. Упоређењем разлика у дистрибуцији силе током различитих фаза хода, установљено је да те разлике нису статистички значајне ${ }^{89}$. Сила реакције подлоге је код статичког једноножног ослонца константна, али се и током фазе једноножног ослонца приликом хода она не мења значајно. То значи да су резултати анализе сила притиска на ацетабуларну хрскавицу код статичког једноножног ослонца пропорционални и слични резултатима код ове фазу хода ${ }^{175}$.

- Истраживање Бергмана и сар. ${ }^{73}$ указују да је доминантни облик оптерећења зглоба кука у свакодневним активностима ходање по равној подлози (82,6-88\% укупног броја циклуса покрета). Убројимо ли ту и периоде једноножног ослонца, који чине око 4\% циклуса покрета, а имајући у виду да су остале моторичке активности (ход по степеницама, чучањ, прелазак из стојећег у седећи положај и обрнуто) углавном у опсегу оптерећења од 61-107\% у односу на оно при ходању, произилази да је 92,5\% обима оптерећења могуће валидно описати анализом позиције статичког једноножног ослонца.

Из наведеног следи да је позиција једноножног ослонца репрезентативна за истраживања дејства силе на хрскавицу зглоба кука. 


\section{Биомеханички параметри зглоба кука}

\section{МАКСИМАЛНИ ПРИТИСАК НА АРТИКУЛАРНЕ ПОВРШИНЕ (Рmax)}

Утврђено је да је здрав зглоб кука има значајну биомеханичку резерву: према истраживањима Бергмана и сар., способан је да поднесе оптерећење и до девет пута веће од телесне тежине читавог тела, али је ипак оно значајно мање при свакодневним радњама: од 0,26\% ТТ код устајања из седећег положаја, до $260 \%$ ТТ код силаска низ степенице ${ }^{176,177}$. Максимални притисак при нормалном ходу је мерен у више истраживања и добијене су вредности од 2,78 $\mathrm{MPa}^{178}, 3,0$ $\mathrm{MPa}^{79}, 3,26 \mathrm{MPa}^{179}, 3,69 \mathrm{MPa}^{180}, 5,5 \mathrm{MPa}^{181}, 10,78 \mathrm{MPa}^{86}$, до $11,38 \mathrm{MPa}^{182}$. При другим активностима притисак је нешто већи: од $3,31 \mathrm{MPa}^{179}$, преко 11,61 $\mathrm{MPa}^{86}$ до $11,66 \mathrm{MPa}^{182}$ при ходу уз степенице; 4,67 $\mathrm{MPa}^{179}, 11,63 \mathrm{MPa}^{182}$ односно 12,73 $\mathrm{MPa}^{86}$ при ходу низ степенице, а сличне вредности су и при чучању и устајању из седећег положаја ${ }^{182}$. У нашем истраживању код здравих кукова измерен је релативно низак притисак на артикуларне површине од 0,82+/-0,43 MPa, вероватно захваљујући оштрим инклузионим критеријумима циркуларности и наткровљености код те групе, а нарочито узевши у обзир да величина ЦЕ угла статистички високо значајно негативно корелира са максималним притиском на зглобне хрскавице $\left(\mathrm{R}_{\mathrm{Pmax}}=-0,427\right)$. У испитиваној групи максимални притисак је имао двоструко веће вредности (медијана 1,69 МРа и изражено варирање од 0,15$17,4 \mathrm{MPa})$.

\section{РЕЗУЛТАНТНА СИЛА У ЗГЛОБУ КУКА}

Максималне силе које делују на зглоб кука су испитиване применом методе анализе коначних елемената, и на основу теоријских литературних података за статички једноножни ослонац здравог зглоба кука, уз телесну тежину од $74 \mathrm{~kg}$, прорачуната је максимална резултантна сила од $2448 \mathrm{~N}$, која производи максимални контактни притисак од 13,06 $\mathrm{MPa}^{87}$. Други аутори при сличним условима оптерећења наводе опсег од 1800-3900 N, мерено помоћу сензором опремљене парцијалне протезе зглоба кука ${ }^{177}$. Поређења ради, у истом истраживању је забележена и максимална сила приликом спотицања и износила је око $11000 \mathrm{~N}$. 


\section{НОРМАЛИЗОВАНИ ИНДЕКС ГРАДИЈЕНТА ПРИТИСКА (Gp/Wb)}

Вредност која описује однос наткровљености зглоба кука и дистрибуције притиска на латералној ивици ацетабулума испитивана је на одраслим здравим куковима ${ }^{20,99}$ и резултати су се кретали у опсегу од $-44,5$ до -26,05 (мањи број означава повољнију вредност) уз знатне варијације (у другој студији, на пример, коефицијент варијације је износио 64,7\%). У нашем истраживању средња вредност у испитиваној групи износила је преоперативно 4,67 а постоперативно 0,48. Просечне вредности у негативној контролној групи (здрави кукови) износила је -1,02. Пошто Gp/Wb у аналитичко-геометријском смислу представља нагиб тангенте градијента притиска на латералном рубу ацетабулума (дакле тригонометријску величину), ради директног упоређења је неопходно трансформисати податке у линеарну скалу. Наши подаци за здраве кукове, мерене у адолесцентном узрасту, се од литературних разликују (што тумачимо разликама у конституцији адолесцената и одраслих особа) али и даље се налазе унутар опсега здравих кукова.

Уочили смо сагласност стандардног дијагностичког критеријума за дисплазију зглоба кука (ЦЕ угао мањи од 25 степени) са биомеханичким критеријумом $(\mathrm{Gp} / \mathrm{Wb}>0)$ предложеним од стране Помпеа и сарадника ${ }^{99}$. Однос вредности ова два параметра у испитиваној групи приказан је на Графикону 2.

Графикон 2. Однос ЦЕ угла и $\mathrm{Gp} / \mathrm{Wb}$ у испитиваној групи- мерење 1

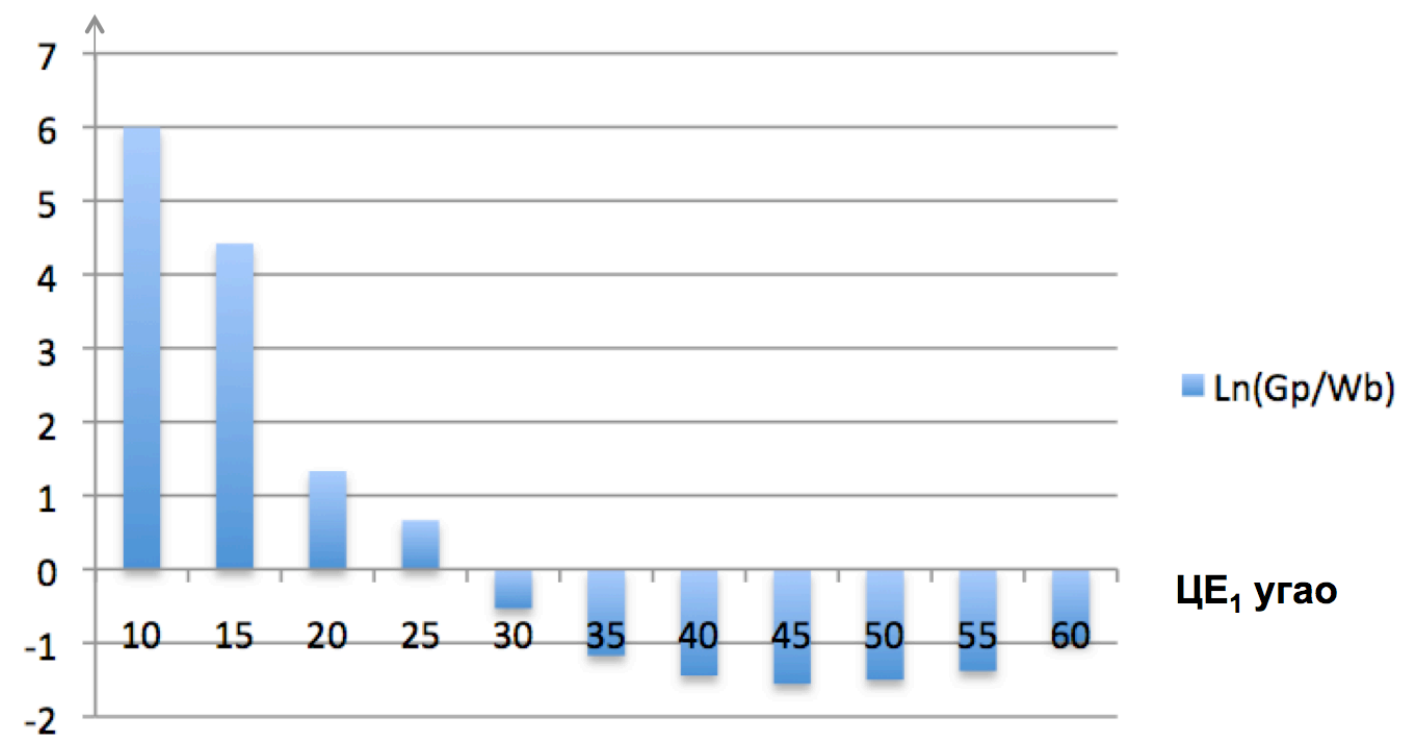




\section{Биомеханички ефекат троструке остеотомије карлице}

За разлику од троструке остеотомије карлице, утицај Ганцове периацетабуларне остеотомије ${ }^{58}$ досада је опсежно биомеханички истраживан. На пример, мерењем на клиничком материјалу и потом применом анализе коначних елемената, максимални притисак на ацетабуларну хрскавицу код диспластичних кукова је износио 3,6+/-1,7 МРа а Вибергов ЦЕ угао од 9,8+/-7,83. Ове вредности су смањене на просечно 2,0+/-0,57 МРа (односно за 35,8\% ), а ЦЕ угао је повећан за просечно за $84,3 \%$. и просечно је износио $30,9+/-8,05$ степени $^{169}$. Наш клинички материјал у испитиваној групи је просечно био за трећину мање диспластичан, и упола мањег максималног притиска. Након операције троструке остеотомије измерене вредности су и даље биле знатно повољније него што други аутори након Ганцове остеотомије наводе: ЦЕ угао износи 33,45 степени а Рmax је био $0,91 \mathrm{MPa}$.

Арман и сар (2005) су установили да се након остеотомије носећа површина не мења значајно, али да се вектор максималног притиска преместио у повољнији положај $^{82}$. Дебљина хрскавице у краткорочној проспективној студији Меленбурга и сар. (2010) се током 2,5 година након периацетабуларне остеотомије није значајно променила ${ }^{183}$. У математичком моделу који смо ми применили, овом параметру одговара $\Theta$-pol параметар и он се статистички високо значајно променио: са преоперативних 43,44+/-13,55 степени на свега 15,85 степени након операције.

Генда и сар. (1995) су утврдили да је утицај Виберговог ЦЕ угла на вредност максималне силе притиска у зглобу занемарљива за углове преко 20 степени $^{184}$. Међутим, други истраживачи нису успели да покажу да постоперативно успостављање нормалних вредности Виберговог ЦЕ угла реституише и вредности максималног притиска на оне измерене код здравих кукова, и као разлог наводе поремећај конгруенције, који се периацетабуларном остеотомијом не може поправити ${ }^{82}$. У нашем материјалу, анализирајући три сукцесивна мерења временски удаљена просечно приближно 3,5 година, установили смо да ЦЕ угао остаје увећај, те да се притисак одржава на оствареном ниском нивоу, упркос томе што телесна тежина константно расте. 
Да конгруенција значајно утиче на величину максималног притиска показују и истраживања рађена на пацијентима оболелим од Лег-Калве-Пертесове болести, где су Парк и сар. добили резултате у опсегу од 2,3-6,5 $\mathrm{MPa}^{85}$. Наше истраживање није могло потврдити ове наводе, вероватно због тога што математички модел који смо користили мора да се посебно модификује да би валидно прорачунавао вредности код несферичне главе фемура.

Обим покрета у оперисаном зглобу кука у нашој студији је без клинички значајних промена у односу на преоперативно стање. Квалитет покрета при ходу и функција абдукторне мускулатуре значајно су побољшани: након операције храмајући ход смањен је троструко, а гегање четири пута (са преоперативних $23,9 \%$ на свега 5,6\%). Валидност ових података огледа се у наводима Карама и cap., који су показали да се мерљиви параметри нормалног хода (дужина корака, каденца, брзина хода и проценат временског интервала трајања једноножног ослонца у циклусу корака) након примене остеотомије карлице поправљају на физиолошки ниво након приближно годину дана ${ }^{95}$. Просечни интервал између преоперативног и завршног налаза у нашем истраживању је оно 3,5 година, тако да су подаци о постоперативном функционалном статусу ослобођени утицаја процеса операције и рехабилитације, односно валидно упоредиви са преоперативним.

Трострука остеотомија не доводи до значајног помераја центра ротације зглоба кука дуж вертикалне осе. Ову теоријску претпоставку наше истраживање поткрепљује кроз преоперативни однос дужина ногу, који се није значајно променио након операције. Сматрамо да захваљујући томе у нашој студији не само да није установљено повећање нормализоване резултантне силе мишићне силе након операције, већ је она смањена за око 3\% уз високу статистичку значајност. Поређења ради, дистализација центра ротације зглоба кука која се дешава при Салтеровој остеотомији карлице доводи до повећане тензије илиопсоаса од 4\% (због чега се ради тенотомија) и глутеус медијуса за $6 \%{ }^{185}$. 


\section{Предиктивни фактори резултата лечења}

Марфи и Дешмук (2002) су уочили три предиктивна фактора лошег резултата код периацетабуларне остеотомије: то су присуство дегенеративних промена ацетабулума услед касно индикованог оперативног лечења, асферичност главе фемура и мали постоперативни Вибергов ЦЕ угао, без обзира на преоперативне његове вредности ${ }^{144}$. Узраст, телесна тежина, величина дисплазије нису показали статистички значајну предиктивну вредност. У њиховом истраживању нису испитивани биомеханички параметри силе и притиска у зглобу кука. Наша запажања потврђују јасну предиктивну вредност ЦЕ угла и то двојаку: високо статистички значајну за постоперативни анатомски исход, а на граници значајности уз преоперативни квалитет хода за функционални исход.

Мавчич и сар. (2008) су установили да ЦЕ угао има предиктивну вредност за појаву коксартрозе само код благе дисплазије, али да је бољи предиктивни фактор одређивање кумулативног максималног притиска на ацетабуларну хрскавицу ${ }^{93,186}$. У нашем истраживању веома близу границе статистичке значајности (за анатомски исход) су два преоперативна параметра (полупречник ротације зглоба кука и нормализована резултантна сила у зглобу) што је затечено стање на презентацији пацијента, али и један постоперативни параметар- постоперативни нормализовани индекс градијента притиска $(\mathrm{Gp} / \mathrm{Wb})$, док његова преоперативно измерена вредност није показала значајан предикторни потенцијал за анатомски или функционални завршни исход. Овај важан налаз потврђује запажања и самих аутора математичког модела" ${ }^{99}$, који су утврдили да је Gp/Wb пропорционалан како степену дисплазије зглоба кука, тиме и дегенеративних оштећења мерених Херисовим скором за кук (Harris hip score) ${ }^{187}$. Наиме, сматрамо да преоперативно измерени $\mathrm{Gp} / \mathrm{Wb}$ није статистички повезан са удаљеним исходом, иако показује неповољне биомеханичке услове (просечно је износио 4,67), захваљујући недовољно дугој кумулативној експозицији код наших релативно младих пацијената. Они имају болне тегобе и поремећен ход, али индикациони услови за троструку остеотомију искључују оне пацијенте код којих су дегенеративне промене већ видљиве. Узевши у обзир да се операцијом овај параметар значајно побољшава (постоперативна просечна вредност $\mathrm{Gp} / \mathrm{Wb}$ je $-0,48 \mathrm{p}<0,01$ ), позитиван утицај на вероватноћу повољног исхода је очекиван, а нормализовани индекс 
градијента притиска на латералној ивици ацетабулума је схваћен као експланатор ефекта оперативне реоријентације ацетабулума на завршни исход лечења. Ово је веома значајно јер пружа могућност да се прецизно испланира оптимална реоријентација ацетабулума, тиме и побољша завршни налаз и обезбеди повољнији исход оперативног лечења. Ограничавајући фактор у испитивању предикторног ефекта је мали број испитаних случајева, дијагностичка хетерогеност као и релативно кратко просечно праћење од око три и по године.

На крају, поред важности одређивања и праћења предикторниих фактора за исход троструке остеотомије, и сама трострука остеотомија се може посматрати као предикторни фактор у даљој еволуцији тегоба и терапијских могућности. Када је у питању утицај измењених биомеханичких односа након операције троструке остеотомије карлице, на могућности накнадног алоартропластичног лечења, мишљења су подељена: једни аутори сматрају да је уградња тоталне протезе тада отежана ${ }^{188}$, док други сматрају да је тиме алоартропластика уствари олакшана ${ }^{189}$. У нашој средини није било таквих случајева, што у светлу вишедеценијске примене троструке остеотомије карлице представља посредни индикатор њених повољних резултата. 


\section{ЗАКЉУЧАК}

Тенисова трострука остеотомија карлице веома поуздан и ефикасан поступак за савладавање ацетабуларне дисплазије и неподударности зглобних површина у зглобу кука код болесника адолесцентног узраста. Ефекат троструке остеотомије карлице у лечењу поремећених биомеханичких односа карлице и проксималног фемура омогућен је довољном мобилношћу ацетабуларног фрагмента при интраоперативној реоријентацији (што обезбеђује повећање носећу површину у антеролатералном делу зглоба) без значајне промене вертикалне позиције центра ротације зглоба у односу на труп (односно без промене у дужини оперисаног екстремитета).

На тај начин се обезбеђује постизање повољније дистрибуције силе притиска на ацетабуларну хрскавицу, и обезбеђује добар исход лечењапревенција дегенеративног оштећења зглоба и потпуни функционални опоравак.

Примена математичког моделовања зглоба кука значајно доприноси разумевању узрока и механизама настанка многих структурних и функционалних поремећаја зглоба кука. Поред теоријске научне вредности, постоји и емпиријска, клиничка примена: могуће је прорачунати важне биомеханичке параметре који описују механичко оптерећење хрскавице (што је од пресудног утицаја на развој коксартрозе), и имају велики дијагностички значај.

Тродимензионали математички модел зглоба кука заснован на радиограму карлице са куковима, развијен од стране Иглича и сарадника и примењен у овом истраживању, је једноставан за употребу, неинвазиван и валидан у примени на клиничком материјалу. Он омогућава прорачун максималног притиска на зглобне површине (Pmax), нормализоване резултантне силе у зглобу кука $(\mathrm{R} / \mathrm{Wb})$ и нормализованог индекса градијента притиска на латералној ивици ацетабулума ( $\mathrm{Gp} / \mathrm{Wb})$, параметара који имају предиктивну вредност за исход лечења, при чему коришћење нормализације параметара према телесној тежини омогућава упоређење пацијената различите конституције.

Употреба развијених математичких модела се у ортопедској пракси показује као валидна и корисна у дијагностици, преоперативној припреми и постоперативном праћењу резултата лечења, уз последично унапређење квалитета 
и прецизности клиничког рада, а такође и проширење научноистраживачких активности.

Стојећи на раменима наших цењених претходника - пионира универзалне превенције и раног лечења развојног поремећаја кука, и настављајући њихове напоре у сузбијању ацетабуларне дисплазије, предлажемо као даљи правац истраживања примену математичког модела зглоба кука у циљу праћења биомеханичких параметара и пацијената и здравих особа, евалуације садашњих облика лечења зглоба кука и подршке њиховом унапређењу. 


\section{ЛИТЕРАТУРА}

1. Mijač M, Blagotić M, Djordjević Lj, Teofilovski-Parapid G. Anatomija čoveka Osteologija. Beograd: Savremena administracija; 2001.

2. Mrvaljević D. Anatomija donjeg ekstremiteta. Beograd: Savremena administracija; 2002.

3. Grant BC. Grant's atlas of anatomy. Baltimore: Williams \& Wilkins; 1972.

4. Floyd TR., Thompson WC. Manual of Structural Kinesiology. McGraw-Hill Higher Education; 1998.

5. Pomers KS, Homler TE. Exercise Physiology. WBC McGraw-Hill; 1996.

6. Milisavljević M. et al. Klinička anatomija. Beograd: Nauka; 1996.

7. Zec Ž. Osnovi kineziologije. Beograd: Viša medicinska škola; 1984.

8. Zec Ž., Konforti N. Ispitivanje snage mišića-manuelna metoda. Beograd: Viša medicinska škola; 1990.

9. Majkić M. Klinička kineziometrija. Zagreb: Tiskarna Kurir; 1989.

10. Hall JS. Basic Biomechanics. WCB McGraw-Hill; 1995.

11. Strayer LM Jr: Embryology of the human hip joint. Clin Orthop 1971; 74:221.

12. Ortolani M. The classic. Congenital hip dysplasia in the light of early and very early diagnosis. Clin Orthop 1976; 119:6-10.

13. Ponseti IV. Growth and development of the acetabulum in the normal child. J Bone Joint Surg 1978; 60-A:575-85.

14. Harris N. Acetabular growth potential in congenital dislocation of the hip and some factors upon which it may depend. Clin Orthop 1976; 119:99-106.

15. Slavković S, Slavković N. Adolescentni kuk. Beograd: JP PTT saobraćaja Srbija; 2004.

16. Gillingham B, Sanchez A, Wenger D. Pelvic osteotomies for the treatment of hip dysplasia in children and young adults. J Am Acad Orthop Surg 1999; 7:325-37.

17. Hsin J, Saluja R, Eilert RE. Evaluation of the Biomechanics of the Hip following a Triple Osteotomy of the Innominate Bone. J Bone Joint Surg 1996; 78:855-62.

18. Olney B, Latz K, Asher M. Treatment of Hip Dysplasia in Older Children With a Combined One-Stage Procedure. Clin Orthop 1998; 347:.215-23. 
19. Ohashi H, Hirohashi K, Yamano Y. Factors influencing the outcome of Chiari pelvic osteotomy: a long-term follow-up. J Bone Joint Surg Br 2000; 82(4):51725 .

20. Kralj-Iglič V,Dolinar D, Ivanovski M, List I, Daniel M. Role of Biomechanical Parameters in Hip Osteoarthritis and Avascular Necrosis of Femoral Head. In: Naik G (ed). Applied Biological Engineering - Principles and Practice. Rijeka: InTech, 2012; p. 347-64.

21. Vukašinović Z, Zajić Lj, Vukadin O. Radiographic assessment of the hip by measurement of different angles and indices. Acta Orthop Iugos1 1997; 28:27-31.

22. Troelsen A, Jacobsen S, Rømer L, Søballe K. Weightbearing Anteroposterior Pelvic Radiographs are Recommended in DDH Assessment. Clin Orthop Relat Res 2008; 466:813-9.

23. Fujii M, Nakashima Y, Sato T, Akiyama M, Iwamoto Y. Acetabular Tilt Correlates with Acetabular Version and Coverage in Hip Dysplasia. Clin Orthop Relat Res 2012; DOI: 10.1007/s11999-012-2370-z.

24. Trendelenburg F. Über den Gang bei angeborener Hüftgelenksluxation. Deutsche medicinische Wochenschrift 1895; 21:21-4.

25. Albinana J, Dolan LA, Spratt KF, Morcuende J, Meyer MD, Weinstein SL. Acetabular dysplasia after treatment for developmental dysplasia of the hip. Implications for secondary procedures. J Bone Joint Surg Br 2004; 86(6):876-86.

26. Sanchez-Sotelo J, Trousdale RT, Berry DJ, Cabanela ME. Surgical treatment of developmental dysplasia of the hip in adults: I. Nonarthroplasty options. J Am Acad Orthop Surg 2002; 10(5):321-33.

27. Schulitz KP, Roggenland G. Triple osteotomy of the pelvis in dysplastic hip joints in children and adults. Z Orthop Ihre Grenzgeb 1991; 129(3):209-16.

28. Vladimirov B. Periacetabular triple osteotomy of the pelvis. Acta Orthop Iugosl 1997; 28(1):5-8.

29. Peters CL, Fukushima BW, Park TK, Coleman SS, Dunn HK. Triple innominate osteotomy in young adults for the treatment of acetabular dysplasia: a 9-year follow-up study. Orthopedics 2001; 24(6):565-9.

30. Høgh J, Macnicol MF. The Chiari pelvic osteotomy - a long-term review of clinical and radiographic results. J Bone Joint Surg Br 1987; 69(3):365-73. 
31. Wedge JH. Hip pain in adolescense. Clin Orthop 1987; 225:93-103.

32. Salter RB, Hansson G, Thompson GH. Innominate osteotomy in the management of residual congenital subluxation of the hip in young adults. Clin Orthop 1984; 182:53-68.

33. Wedge JH, Wasylenko MJ. The natural history of congenital disease of the hip. J Bone Joint Surg 1979; 61-B:334-8.

34. Ezoe M, Naito M, Asayama I. Muscle Strength Improves after Abductor-sparing Periacetabular Osteotomy. Clin Orthop Relat Res 2006; 444:161-8.

35. Ishida A, Kuwajima SS, Laredo Filho J, Milani C. Salter Innominate Osteotomy in the Treatment of Severe Legg-Calvé-Perthes Disease. J Pediatr Orthop 2004; 24(3):257-64.

36. Geva H, Bialik V, Dimeglio A, Garinkol S. Concepts about prevention as defined by members of the European Pediatric Orthopaedic Society. J Pediatr Orthop Part B 1993; 2:104-7.

37. Tonnis D. Tretment of residual dysplasia after developmental dysplasia of the hip as a prevention of early coxarthrosis. J Pediatr Orthop Part B 1993; 2:133-44.

38. Scott JT, Keith AM, Jeffrey WM. The Periacetabular Osteotomy: Minimum 2 Year Followup in More Than 100 Hips. Clin Orthop 1999; 363:54-63.

39. McCarthy JJ, Fox JS, Gurd AR. Innominate Osteotomy in Adolescents and Adults Who Have Acetabular Dysplasia. J Bone Joint Surg 1996; 78:1455-61.

40. Kuwajima SS, Crawford AH, Ishida A, Roy DR, Filho JL, Milani C. Comparison Between Salter's Innominate Osteotomy and Augmented Acetabuloplasty in the Treatment of Patients with Severe Legg-Calvé-Perthes Disease. J Pediatr Orthop B 2002; 11(1):15-28.

41. Chiari K. Iliac osteotomy in young adults. In: The hip. Prodeedings of the Hip Society. St. Louis: CV Mosby; 1979:260-77.

42. Lack W, Windhager R, Kutschera HP, Engel A. Chiari pelvic osteotomy for osteoarthritis secondary to hip dysplasia. J Bone Joint Surg 1991; 73-B:229-33.

43. Migaud H, Duquennoy A, Gourgeon F, Fontaine C, Pasquier G. Outcome of chiari pelvic osteotomy in adults- 90 hips wuth 2-15 years' follow-up. Acta Orthop Scand 1995; 66:127-31. 
44. Reddy R, Morin C: Chiari osteotomy in Legg-Calvé-Perthes disease. J Pediatr Orthop B 2005; 14(1):1-9.

45. Salter RB. Innominate Osteotomy in the Treatment of Congenital Dislocation and Subluxation of the Hip. J Bone Joint Surg 1961; 43-B(3):518-39.

46. Dogan M, Bozkurt M, Sesen H, Yildirim H. One-stage treatment of congenital severely dislocated hips in older children through various acetabuloplasty techniques 22 children followed for 1-5 years. Acta Orthop 2005; 76(2):212-9.

47. Chaker M, Picault C, Kohler R. Resultats à long terme du traitement de la dysplasie résiduelle de hanche par ostéotomie de salter (édure d'une série de 31 cas). Acta Orthop Belg 2001; 67(1):6-18.

48. Dagher F, Ghanem I, Abiad R, Haykal G , Kharrat K, Phares A. Bernese periacetabular osteogomy for the treatment of the degenerative dyspasic hip. Rev Chir Orthop Reparatrice Appar Mot 2003; 89:125-33.

49. Milani C, Ishida A, Laredo Fj, Napoli MM, Kuwajima SS, Dobashi ET, Adames MK. Avaliação do índice de necrose avascular na luxação congênita do quadril inveterada pelo encurtamento femoral e acetabuloplastia de Salter modificada. Rev Bras Ortop 1996; 31(1):67-74.

50. Chiari K. Ergebnisse mit der Beckenosteotomie als Pfannendachplastik. Z Orthop Ihre Grenzgeb 1955; 87:14 -26.

51. Yanagimoto S, Hotta H, Izumida R, Sakamaki T. Long term Results of Chiari Pelvic Osteotomy in patients with Developmental Dysplasia of the Hip. J Orthop Sci 2005; 10(6):557-63.

52. Betz RR, Kumar SJ, Palmer CT, MasEwen D. Chiari pelvic osteotomy in children and young adults. J Bone Joint Surg 1988; 70-A:182-9.

53. Hulet C, Schiltz D, Vielpeau C, Richter D, Aubrio JH. Treatment of osteoarthritis of the hip joint in young adults by Chiari pelvic osteotomy: mid-term clinical and radiographic results. Rev Chir Orthop Reparatrice Appar Mot 1998; 84(1):41-50.

54. Ishida A, Kuwajima SS, Laredo Filho J, Milani C. Osteotomia de Chiari na doença de Perthes. Rev Bras Ortop 1998; 33(1):1-7.

55. Gotoh E, Inao S, Okamoto T, Ando M. Valgus-extension osteotomy for advanced osteoarthritis in dysplastic hips. J Bone Joint Surg Br 1997; 79-B(4):609-15. 
56. de Kleuver M, Kooijman MA, Pavlov PW, Veth RP. Triple osteotomy of the pelvis for acetabular dysplasia. J Bone Joint Surg Br 1997; 79(2):225-9.

57. Rush J. Chiari osteotomy in the adult - a long-term follow-up study. Aust N Z J Surg 1991; 61(10):761-4.

58. Sanchez-Sotelo J, Trousdale RT, Berry DJ, Cabanela ME. Surgical Treatment of Developmental Dysplasia of the Hip in Adults: I. Nonarthroplasty Options. J Am Acad Orthop Surg 2002; 10:321-33.

59. Van Hellemondt GG, Sonneveld H, Schreuder E, Kooijman P, de Kleuver M. Triple osteotomy of the pelvis for acetabular dysplasia. Results at a mean followup of 15 years. J Bone Joint Surg Br 2005; 87-B(7):911-5.

60. Eren A, Ömeroglu H, Güven M, Ugutmen E, Altintas F. Incomplete triple pelvic osteotomy for the surgical treatment of dysplasia of the hip in adolescents and adults. J Bone Joint Surg Br 2005; 87-B(6):790-5.

61. Tonnis D, Behrens K, Tscharani F. A modified technique of the triple pelvic osteotomy: early results. J Pediatr Orthop 1981; 1(3):241-9.

62. Tonnis D, Arning A, Bloch M, Heinecke A, Kalchschmidt K. Triple pelvic osteotomy. J Pediatr Orthop Part B 1994; 3(1):54-67.

63. Vukašinović Z, Zajić Lj, Slavković S, Vukadin O, Miličković S. Triple pelvic osteotomy, first experience in Yugoslavia. Magyar Traumatologia, Ortopedia, Kezsebeszet, Plasztikai Sebeszet 1999; 2:116-9.

64. Vukašinović Z, Spasovski D, Čobeljić G: Trostruka osteotomija karlice u našoj sredini - osam godina kasnije. Acta Chir Iugos1 2005; 52:55-9.

65. Vukašinović Z, Spasovski D, Živković Z, Slavković N, Cerović S. Triple pelvic osteotomy in the treatment of hip dysplasia. Srp Arh Celok Lek 2009; 137(56):239-48.

66. Vukašinović Z, Pelilllo F, Spasovski D, Šešlija I, Živković Z, Matanović D: Triple pelvic osteotomy for the treatment of residual hip dysplasia - Analysis of complications. Hip International 2009; 19:315-22.

67. Kirschner S, Raab P, Wild A, Krauspe R. Clinical and radiological short- and mid-term results of triple pelvic osteotomy according to Tönnis in adolescents and adults. Z Orthop Ihre Grenzgeb 2002; 140: 523-6. 
68. Davey JP, Santore RF. Complications of periacetabular osteotomy. Clin Orthop 1999; (363):33-7.

69. Hueter C. Anatomische Studien an den Extremitätengelenken Neugeborener und Erwachsener. Virchows Archiv für pathologische Anatomie und Physiologie $1862 ; 25: 572$.

70. Greenwald AS, O'Connor JJ. The transmission of load through human hip joint. J Biomech 1971; 4:507-28.

71. Legal H, Ruder H. Zur biostatischen Analyse des hüft-gelenks. Z Orthop Ihre Grenzgeb 1977; 115(2):215-34.

72. Frost H. Joint anatomy, design, and arthroses: insights of the Utah paradigm. Anat Rec 1999; 255:162-74.

73. Bergmann G, Graichen F, Rohlmann A, Bender A, Heinlein B, Duda GN, Heller MO, Morlock MM. Realistic loads for testing hip implants. Biomed Mater Eng 2010; 20(2):65-75.

74. von Eisenhart-Rothe R, Witte H, Steinlechner M, Müller-Gerbl M, Putz R, Eckstein F. Quantitative Bestimmung der Druckverteilung im Hüftgelenk während des Gangzyklus. Unfallchirurg 1999; 102(8):625-31.

75. Sparks DR, Beason DP, Etheridge BS, Alonso JE, Eberhardt AW. Contact pressures in the flexed hip joint during lateral trochanteric loading. J Orthop Res 2005; 23(2):359-66.

76. Dennison CR, Wild PM, Wilson DR, Gilbart, MK. An in-fiber Bragg grating sensor for contact force and stress measurements in articular joints. Meas Sci Technol 2010; 21(11):115803.

77. Troy KL, Brown TD, Conzemius MG. Contact stress distributions on the femoral head of the emu (Dromaius Novaehollandiae). J Biomech 2009; 42(15): 2495500 .

78. Hamacher P, Rösler H: Die Berechnung von Grosse und Richtung der Hüftgelenksresultierenden im Einzelfall. Arch Orthop Trauma Surg 1971;70: 2635.

79. Ipavec M, Brand RA, Pedersen DR, Mavčič B, Kralj-Iglič V, Iglič A. Mathematical modelling of stress in the hip during gait. J Biomech 1999; 32:1229-35. 
80. Wang XS, Jiang FC, Jian MA, Hou XP. The Peak Stress, Weigh Beared Area And Stress Distributions At Human Hip Joint. Biomed Eng Appl Basis Comm 2006; 18: 19-23.

81. Henderson ER, Marulanda GA, Cheong D, Temple HT, Letson GD. Hip abductor moment arm - a mathematical analysis for proximal femoral replacement. J Orthop Surg Res 2011; 6:6.

82. Armand M, Lepistö J, Tallroth K, Elias J, Chao E. Outcome of periacetabular osteotomy: joint contact pressure calculation using standing AP radiographs, 12 patients followed for average 2 years. Acta Orthop 2005; 76(3):303-13.

83. Bachtar F, Chen X, Hisada T. Finite element contact analysis of the hip joint. Med Biol Eng Comput 2006; 44:643-51.

84. Anderson AE, Ellis BJ, Maas SA, Peters CL, Weiss JA. Validation of Finite Element Predictions of Cartilage Contact Pressure in the Human Hip Joint. J Biomech Eng 2008; 130(5): 051008.

85. Park WM, Kim YH, Kim K, Oh TY. Non-destructive Biomechanical Analysis to Evaluate Surgical Planning for Hip Joint Diseases. Int J Precision Eng Manufact 2009; 10(3):127-31.

86. Anderson AE, Ellis BJ, Maas SA, Weiss JA. Effects of idealized joint geometry on finite element predictions of cartilage contact stresses in the hip. J Biomech 2010; 43(7):1351-7.

87. Zhao X, Chosa E, Totoribe K, Deng G. Effect of periacetabular osteotomy for acetabular dysplasia clarified by three-dimensional finite element analysis. $\mathrm{J}$ Orthop Sci 2010; 15:632-40.

88. Henak CR, Ellis BJ, Harris MD, Anderson AE, Peters CL, Weiss JA. Role of the acetabular labrum in load support across the hip joint. J Biomech 2011; 44(12):2201-6.

89. Harris MD, Anderson AE, Henak CR, Ellis BJ, Peters CL, Weiss JA. Finite element prediction of cartilage contact stresses in normal human hips. J Orthop Res. 2012; 30(7):1133-9.

90. Hadley NA, Brown TD, Weinstein SL. The effects of contact stress pressure elevations and aseptic necrosis in the long-term outcome of congenital hip dislocation. J Orthop Res 1990; 8:504-13. 
91. Mavčič B, Pompe B, Antolič V, Daniel M, Iglič A, Kralj-Iglič V. Mathematical estimation of stress distribution in normal and dysplastic human hip. J Orthop Res 2002; 20:1025-30.

92. Genda E, Iwasaki N, Li G, MacWiliams BA, Barrance PJ, Chao EYS. Normal hip contact pressure distribution in single parameters. J Biomech 2001. 34:895-905.

93. Mavčič B, Iglič A, Kralj-Iglič V, Brand R, Vengust R. Cumulative hip contact stress predicts osteoarthritis in DDH. Clin Orthop Relat Res 2008; 466(4):884-91.

94. Kim JE, Zuoping L, Ito Y, Huber CD, Shih AM, Eberhardt AW, Yang KH, King AI, Soni BK. Finite element model development of a child pelvis with optimization-based material identification. J Biomech 2009; 42:2191-5.

95. Karam MD, Gao Y, McKinley T. Assessment of walking pattern pre and post peri-acetabular osteotomy. Iowa Orthop J 2011; 31:83-9.

96. Kralj M, Mavčič B, Antolič V, Iglič A, Kralj-Iglič V. The Bernese periacetabular osteotomy: clinical, radiographic and mechanical 7-15-year follow-up of 26 hips. Acta Orthop 2005; 76(6):833-40.

97. Brand R, Iglič A, Kralj-Iglič V. Contact stresses in the human hip: implications for disease and treatment. Hip Int 2001; 11(3):117-26.

98. Dolinar D, Antolič V, Herman S, Iglič A, Kralj-Iglič V, Pavlovčič V. Influence of contact hip stress on the outcome of surgical treatment of hips affected by avascular necrosis. Arch Orthop Trauma Surg 2003; 123(10):509-13.

99. Pompe B, Daniel M, Sochor M, Vengust R, Kralj-Iglič V, Iglič A. Gradient of contact stress in normal and dysplastic human hips. Med Eng Phys 2003; 25(5):379-85.

100. Vengust R, Daniel M, Antolič V, Zupanc O, Iglič A, Kralj-Iglič V. Biomechanical evaluation of hip joint after Salter innominate osteotomy - a long-term follow-up study. Arch Orthop Trauma Surg 2001; 121(9):511-6.

101. Iglič A, Kralj-Iglič V, Antolič V, Srakar F, Stanič U. Effect of the Periacetabular Osteotomy of the Stress on the Human Hip Joint Articular Surface. IEEE Trans Rehab Eng 1993; 1:207-12.

102. Herman S, Jaklič A, Herman S, Iglič A, Kralj-Iglič V. Hip stress reduction after Chiari osteotomy. Med Biol Eng Comput 2002; 40(4):369-75. 
103. Hailer NP, Soykaner L, Ackermann H, Rittmeister M. Triple osteotomy of the pelvis for acetabular dysplasia. Age at operation and the incidence of nonunions and other complications influence outcome. J Bone Joint Surg $\operatorname{Br} 2005$; 87$\mathrm{B}(12): 1622-6$.

104. Böhm P, Brzuske A. Salter Innominate Osteotomy for the Treatment of Developmental Dysplasia of the Hip in Children. Results of Seventy-three Consecutive Osteotomies After Twenty-six to Thirty-five Years of Follow-up. J Bone Joint Surg Am 2002; 84:178-86.

105. Ferguson S, Bryant J, Ganz R, Ito K. The influence of the acetabular labrum on hip joint cartilage consolidation: a poroelastic finite element model. J Biomech 2000; 33(8) 953-60.

106. Wei HW, Sun SS, Jao SHE, Yeh CR, Cheng CK. The influence of mechanical properties of subchondral plate, femoral head and neck on dynamic stress distribution of the articular cartilage. Med Eng Phys 2005; 27:295-304.

107. Russell ME, Shivanna KH, Grosland NM, Pedersen DR. Cartilage contact pressure elevation in dysplastic hips: a chronic overload model. J Orthop Surg Res 2006; 3:1-6.

108. Mow VC, Lai WM. Recent developments in synovial joint biomechanics. SIAM Review 1980; 22(3):275-317.

109. Armstrong CG, Mow VC. Variations in the intrinsic mechanical properties of human articular cartilage with age, degeneration, and water content. J Bone Joint Surg Am 1982; 64(1):88-94.

110. Macirowski T, Tepic S, Mann RW. Cartilage stresses in the human hip joint. J Biomech Eng 1994; 116(1):10-8.

111. Forster H, Fisher J, Dowson D, Wright V. The effect of stationary loading on the friction and boundary lubrication of articular cartilage in the mixed lubrication regime. In: Dowson D, Taylor CM, Childs THC, Dalmaz G, editors. Proceedings of the 21st Leeds/Lyon Symposium on Tribology, Lubrication and Lubricants. Amsterdam: Elsevier Science, 1995; p. 71-84.

112. Ateshian GA, Wang HQ, Lai WM. The role of interstitial fluid pressurization and surface porosities on the boundary friction of articular cartilage. J Tribol 1998; 120(2):241-8. 
113. Ateshian GA. A theoretical formulation for boundary friction in articular cartilage. J Biomech Eng 1997; 119(1):81-6.

114. Soltz MA, Ateshian GA. Experimental verification and theoretical prediction of cartilage interstitial fluid pressurization at an impermeable contact interface in confined compression. J Biomech 1998; 31(10):927-34.

115. Persson BNJ. Sliding friction. second ed. Berlin: Springer-Verlag, 2000; p. 515.

116. Park S, Krishnan R, Nicoll SB, Ateshian GA. Cartilage interstitial fluid load support in unconfined compression. J Biomech 2003; 36:1785-96.

117. Athanasiou KA, Agarwal A, Dzida FJ. Comparative study of the intrinsic mechanical properties of the human acetabular and femoral head cartilage. $J$ Orthop Res 1994; 12(3):340-9.

118. Nishii T, Shiomi T, Tanaka H, Yamazaki Y, Murase K, Sugano N. Loaded cartilage T2 mapping in patients with hip dysplasia. Radiology 2010; 256(3):95565.

119. Ferguson SJ, Bryant JT, Ganz R, Ito K. An in vitro investigation of the acetabular labral seal in hip joint mechanics. J Biomech 2003; 36(2):171-8.

120. Carter DM, Wong M. Modelling cartilage mechanobiology. Philos Trans R Soc Lond B Biol Sci 2003; 358:1461-71.

121. Ateshian GA, Ellis BJ, Weiss JA. Equivalence between short-time biphasic and incompressible elastic material responses. J Biomech Eng 2007; 129(3):405-12.

122. Greaves LL, Gilbart MK, Yung A, Kozlowski P, Wilson DR. J Biomech 2009; 42:349-54.

123. Stammberger T, Herberhold C, Faber S, Englmeier KH, Reiser M, Eckstein F. A method for quantifying time dependent changes in MR signal intensity of articular cartilage as a function of tissue deformation in intact joints. Med Eng Phys 1998; 20(10):741-9.

124. Herberhold C, Faber S, Stammberger T, Steinlechner M, Putz R, Englmeier KH, Reiser M, Eckstein F. In situ measurement of articular cartilage deformation in intact femoropatellar joints under static loading. J. Biomech 1999; 32(12):128795.

125. Brand RA. Joint contact stress: a reasonable surrogate for biological processes? Iowa Orthop J 2005; 25:82-94. 
126. Repo RU, Finlay JB: Survival of articular cartilage after controlled impact. J Bone Joint Surg Am 1979; 59:1068-76.

127. Pauwels F: Biomechanics of the normal and diseased hip: theoretical foundation. Technique and results of treatment. New York: Springer; 1976.

128. Ferguson S, Bryant J, Ganz R, Ito K. The acetabular labrum seal: a poroelastic finite element model. Clin Biomech 2000; 15(6), 463-8.

129. Barker MK, Seedhom BB. The relationship of the compressive modulus of articular cartilage: does cartilage optimize its modulus so as to minimize the strains arising in it due to the prevalent loading regime? Rheumatology 2001; 40:274-84.

130. Brown C, Nguyen T, Moody H, Crawford R, Oloyede A. Assessment of common hyperelastic constitutive equations for describing normal and osteoarthritic articular cartilage. Proceedings of I Mech E Part H: J Eng Med 2009; 223:643-52.

131. Zuoping L, Alonso JE, Kim JE, Davidson JS, Etheridge BS, Eberhardt AW. Three-dimensional finite element models of the human pubic symphysis with viscohyperelatic soft tissues. Ann Biomed Eng 2006; 34(9):1452-62.

132. Daniel M, Sochor M, Iglič A, Kralj-Iglič V. Hypothesis of regulation of hip joint cartilage activity by mechanical loading. Med Hypotheses 2003; 60(6):936-7.

133. Wilson DR, McWalter EJ, Johnston JD. The measurement of joint mechanics and their role in osteoarthritis genesis and progression. Rheum Dis Clin North Am 2008; 34:605-22.

134. Klaue K, Durnin CW, Ganz R. The acetabular rim syndrome. A clinical presentation of dysplasia of the hip. J Bone Joint Surg Br 1991; 73(3):423-9.

135. McCarthy JC, Noble PC, Schuck MR, Wright J, Lee J. The watershed labral lesion: its relationship to early arthritis of the hip. J Arthroplasty 2001; 16(8 Suppl 1):81-7.

136. McCarthy JC, Noble PC, Schuck MR, Wright J, Lee J. The Otto E. Aufranc Award: The role of labral lesions to development of early degenerative hip disease. Clin Orthop Relat Res 2001; (393):25-37.

137. Wu JZ, Herzog W, Epstein M. Effects of inserting a pressensor film into articular joints on the actual contact mechanics. J Biomech Eng 1998; 120(5):655-9. 
138. Jacobsen S. Adult hip dysplasia and osteoarthritis. Studies in radiology and clinical epidemiology. Acta Orthop Suppl 2006; 77(324):1-37.

139. Lubovsky O, Wright D, Hardisty M, Kiss A, Kreder H, Whyne C. Acetabular orientation: anatomical and functional measurement. Int J CARS 2012; 7:233-40.

140. Murphy SB, Ganz R, Muller ME. The prognosis in untreated dysplasia of the hip. A study of radiographic factors that predict the outcome. J Bone Joint Surg Am 1995; 77(7):985-9.

141. Trousdale RT, Ekkernkamp A, Ganz R, Wallrichs SL. Periacetabular and intertrochanteric osteotomy for the treatment of osteoarthrosis in dysplastic hips. J Bone Joint Surg Am 1995; 77(1):73-85.

142. Matta JM, Stover MD, Siebenrock K. Periacetabular osteotomy through the Smith-Petersen approach. Clin Orthop 1999; (363):21-32.

143. Bachus KN, DeMarco AL, Judd KT, Horwitz DS, Brodke DS. Measuring contact area, force, and pressure for bioengineering applications: Using Fuji Film and TekScan systems. Med Eng Phys 2006; 28: pp. 483-8.

144. Murphy S, Deshmukh R. Periacetabular osteotomy: preoperative radiographic predictors of outcome. Clin Orthop Relat Res 2002; 405:168-74.

145. Johnston R, Brand R, Crowninshield R. Reconstruction of the hip. A mathematical approach to determine optimum geometric relationships. J Bone Joint Surg Am 1979; 61:639-52.

146. Iglič, A, Daniel M, Kralj-Iglič V, Antolič V, Jaklič, A. Peak hip-joint contact stress in male and female populations. J Musculoskeletal Res 2001; 5:17-21.

147. Iglič A, Šrakar F, Antolič V, Kralj-Iglič V, Batagelj V. Matematička analiza osteotomije po Chiariju. Acta orthop Iugosl 1990;20(2-3):35-9.

148. Murphy SM, Deshmukh R. Periacetabular Osteotomy: Preoperative Radiographic Predictors of Outcome. Clin Orthop 2002; 405:168-74.

149. Zupanc O, Antolič V, Iglič A, Jaklič A, Kralj-Iglič V, Stare J, Vengust R. The assessment of contact stress in the hip joint after operative treatment for severe slipped capital femoral epiphysis. Int Orthop 2001; 25(1):9-12.

150. Iglič A, Kralj-Iglič V, Daniel M, Maček-Lebar A. Computer determination of stress distribution and size of weight bearing area in the human hip joint. Comput Methods Biomech Biomed Engin 2002; 5(2):185-92. 
151. Andrew E. Anderson AE, Ellis BJ, Maas SA, Weiss JA. Effects of Idealized Joint Geometry on Finite Element Predictions of Cartilage Contact Stresses in the Hip. J Biomech. 2010; 43(7):1351-7.

152. Tönnis, A. Heinecke. Acetabular and Femoral Anteversion: Relationship with Osteoarthritis of the Hip. J Bone Joint Surg 1999; 81:1747-70.

153. Srakar F, Iglič A, Antolič V, Herman S. Computer simulation of periacetabular osteotomy. Acta Orthop Scand 1992; 63(4):411-2.

154. http://rsbweb.nih.gov/ij/ (17.11.2011.).

155. http://physics.fe.uni-lj.si/projects/orthopaedic.htm (17.11.2011.).

156. Vukašinović Z, Spasovski D, Vučetić Č, Čobeljić G, Živković Z, Matanović D. Triple pelvic osteotomy in the treatment of Legg-Calve-Perthes disease. Int Orthop 2009; 33(5):1377-83.

157. http://www.statpages.org (17.11.2011.)

158. Cooperman DR, Wallensten R, Stulberg SD. Acetabular dysplasia in the adult. Clin Orthop 1983; 175:79-85.

159. Trumble SJ, Mayo KA, Mast JW. The periacetabular osteotomy. Minimum 2 year followup in more than 100 hips. Clin Orthop 1999; 363:54-63.

160. Harris WH. Etiology of osteoarthritis of the hip. Clin Orthop 1986; 213:20-33.

161. Michaeli DA, Murphy SB, Hipp JA. Comparison of predicted and measured contact pressures in normal and dysplastic hips. Med Eng Phys 1997; 19(2):1806.

162. Reynolds D, Lucas J, Klaue K. Retroversion of the acetabulum. A cause of hip pain. J Bone Joint Surg Br 1999; 81(2):281-8.

163. Murphy S, Tannast M, Kim YJ, Buly R, Millis MB. Debridement of the adult hip for femoroacetabular impingement: indications and preliminary clinical results. Clin Orthop Relat Res 2004; (429):178-81.

164. Beck M, Kalhor M, Leunig M, Ganz R. Hip morphology influences the pattern of damage to the acetabular cartilage: femoroacetabular impingement as a cause of early osteoarthritis of the hip. J Bone Joint Surg Br 2005; 87(7):1012-8.

165. Kim WY, Hutchinson CE, Andrew JG, Allen PD. The relationship between acetabular retroversion and osteoarthritis of the hip. J Bone Joint Surg Br 2006; 88(6):727-9. 
166. Recnik G, Vengust R, Kralj-Iglic V, Vogrin M, Krajnc Z, Kramberger S. Association between subclinical acetabular dysplasia and a younger age at hip arthroplasty in idiopathic osteoarthritis. J Int Med Res 2009; 37(5):1620-5.

167. Aronson J. Osteoarthritis of the young adult hip: etiology and treatment. Instr Course Lect 1986; 35:119-28.

168. Wiberg G. Studies on dysplastic acetabula and congenital subluxation of the hip joint. With special reference to the complication of osteoarthritis. Acta Chir Scand 1939; 83(Supp 58): 5-135.

169. Armiger RS, Armand M, Tallroth K, Lepistö J, Mears SC. Three-dimensional mechanical evaluation of joint contact pressure in 12 periacetabular osteotomy patients with 10-year follow-up. Acta Orthop 2009; 80(2):155-61.

170. Troelsen A, Rømer L, Kring S, Elmengaard B, Søballe K. Assessment of hip dysplasia and osteoarthritis: variability of different methods. Acta Radiol 2010; 51(2):187-93.

171. Debevec H, Pedersen DR, Iglič A, Daniel $M$. One-legged stance as a representative static body position for calculation of hip contact stress distribution in clinical studies. J Appl Biomech 2010; 26(4):522-5.

172. Bay BK, Hamel AJ, Olson SA, Sharkey NA. Statically equivalent load and support conditions produce different hip joint contact pressures and periacetabular strains. J Biomech 1997; 30:193-6.

173. Mavcic B, Antolic V, Brand R, Iglic A, Kralj-Iglic V, Pedersen DR. Peak contact stress in human hip during gait. Pflugers Arch 2000; 440(5 Suppl):R177-8.

174. Stansfield BW, Nicol AC, Paul JP, Kelly IG, Graichen F, Bergmann G. Direct comparison of calculated hip joint contact forces with those measured using instrumented implants. An evaluation of a three-dimensional mathematical model of the lower limb. J Biomech 2003; 36:929-36.

175. Daniel M, Antolič V, Iglič A, Kralj-Iglič V. Determination of contact hip stress from nomograms based on mathematical model. Med Eng Phys 2001;23(5):34757.

176. Crowninshield RD, Johnston RC, Andrews JG, Brand RA. A biomechanical investigation of the human hip. J Biomec 1978; 11(1-2):75-85. 
177. Bergmann G, Graichen F, Rohlmann A. Hip joint loading during walking and running, measured in two patients. J Biomech 1993; 26(8):969-90.

178. Pawaskar SS, Ingham E, Fisher J, Jin Z. Fluid load support and contact mechanics of hemiarthroplasty in the natural hip joint. Med Eng Phys. 2011; 33(1):96-105.

179. Yoshida H, Faust A, Wilckens J, Kitagawa M, Fetto J, Chao EY. Threedimensional dynamic hip contact area and pressure distribution during activities of daily living. J Biomech 2006; 39(11):1996-2004.

180. Krebs DE, Elbaum L, Riley PO, Hodge WA, Mann RW. Exercise and gait effects on in vivo hip contact pressures. Phys Ther 1991; 71(4):301-9.

181. Hodge WA, Carlson KL, Fijan RS, Burgess RG, Riley PO, Harris WH, Mann RW. Contact pressures from an instrumented hip endoprosthesis. J Bone Joint Surg Am 1989; 71(9):1378-86.

182. Wang XS, Wang TY, Jiang FC, Duan Y. The Hip Stress Level Analysis For Human Routine Activities. Biomed Eng Appl Basis Comm 2005;17:153-8.

183. Mechlenburg I, Nyengaard JR, Gelineck J, Soballe K, Troelsen A. Cartilage thickness in the hip measured by MRI and stereology before and after periacetabular osteotomy. Clin Orthop Relat Res 2010; 468(7):1884-90.

184. Genda E, Konishi N, Hasegawa N, Miura T. A computer simulation study of normal and abnormal hip joint contact pressure. Arch Orthop Trauma Surg 1995; 114:202-6.

185. Rab GT: Biomechanical aspects of Salter osteotomy. Clin Orthop and Relat Res 1978; 132:82-7.

186. Recnik G, Kralj-Iglic V, Iglic A, Antolic V, Kramberger S, Rigler I, Pompe B, Vengust R. The role of obesity, biomechanical constitution of the pelvis and contact joint stress in progression of hip osteoarthritis. Osteoarthritis Cartilage 2009; 17(7):879-82.

187. Harris WH: Traumatic arthritis of the hip after dislocation and acetabular fractures: treatment by mold arthroplasty. An end-result study using a new method of result evaluation. J Bone and Joint Surg 1969;51-A:737-55.

188. Peters CL, Beck M, Dunn HK: Total hip arthroplasty in young adults after failed triple innominate osteotomy. J Arthroplasty 2001; 16(2):188-95. 
189. Santore RF: Hip reconstruction: Nonarthroplasty. In: Callaghan JJ, Dennis DA, Papferosky WG, Rosenberg AG, eds.: Hip and knee reconstruction. Rosemont: American Academy of Orthopaedic Surgeons, 1995: 110-5. 


\section{БИОГРАФСКИ ПОДАЦИ}

Др Душко Спасовски рођен је 1.10.1971. године у Београду.

Након завршетка средње школе, 1990. године је уписао Медицински факултет Универзитета у Београду. Дипломирао је 1996. године са просечном оценом 9,64, и исте године на овом факултету уписао последипломске студије из области ортопедије, које је завршио 2007. године одбранивши магистарску тезу под називом "Могућности и предности трипле остеотомије карлице у лечењу дисплазије кука у адолесценцији". Специјалистичке студије из ортопедије је уписао 1998. године, такође на Медицинском факултету Универзитета у Београду, а завршио 2005. године.

Уз студије медицине, 1993. године је као редован студент паралелно уписао Факултет спорта и физичке културе Универзитета у Београду, где је дипломирао са просечном оценом 9,35.

Од 2000-2007. године је био запослен на Институту за ортопедску хирургију и трауматологију Клиничког центра Србије у Београду, радећи као лекар на специјализацији, а потом и као специјалиста ортопед на Одељењу микрохирургије, Одељењу спиналне трауме и Одељењу за хирургију рамена.

Од 2007. године је запослен на Институту за ортопедско-хируршке болести “Бањица” у Београду, где и данас ради у Служби за дечју ортопедију и трауматологију.

У току специјализације 2001. године је обавио једномесечни студијски боравак на Одељењу за спортску оропедију Техничког универзитета у Минхену, Немачка. Учествовао је у више интернационалних и домаћих курсева из различитих области ортопедије.

Кандидат је поред здравствене показао и значајно интересовање за наставну и научну делатност.

Током студија је на оба факултета био демонстратор: на предметима Медицинска статистика и информатика (1991-1992. године), и Хистологија са ембриологијом (1992-1996. године) на Медицинском факултету, и на предмету Корективна гимнастика (1996-1997. године) на Факултету спорта и физичке културе. 
Као предавач је био ангажован на Спортској академији у Београду од 20022007. године на предмету Биомедицинске основе спорта, и на Високој спортској и здравственој школи у Београду од 2007-2011. године на предмету Хирургија са ортопедијом и трауматологијом. За потребе наставе на поменутим школама издао је два уџбеника из функционалне анатомије и приредио Практикум из хирургије.

На конкурсу Медицинског факултета Универзитета у Београду 2011. године је изабран за клиничког асистента за наставну област Ортопедија на предмету Хирургија са анестезиологијом.

Др Душко Спасовски је у периоду од 1998-2000. године био стипендиста Министарства науке и технологије, уз учешће на пројекту Министарства под називом „Механизми оштећења и опоравка ћелија“. Тренутно је учесник подпројекта 5 под називом “Ретке болести у ортопедији”, у оквиру текућег интердисциплинарног интегративног истраживачког пројекта „ Ретке болести: молекуларна патофизиологија, дијагностички и терапијски модалитети и социјални аспекти (41004)““ под окриљем Министарства науке и технолошког развоја Србије.

Кандидат је досада објавио 54 публикације. и међу њима укупно 40 радова штампаних у целости. Од тих радова 14 је објављено у часописима индексираним на СЦИ листи и осам у часописима индексираним на поширеној СЦИ листи.

Течно говори енглески и шпански језик.

Ожењен је и отац троје деце. 


\section{Прилог 1.}

\section{Изјава о ауторству}

Потписани-а Душко Спасовски

број уписа

\section{Изјављујем}

да је докторска дисертација под насловом

Биомаханичка анализа троструке остеотомије карлице

- резултат сопственог истраживачког рада,

- да предложена дисертација у целини ни у деловима није била предложена за добијање било које дипломе према студијским програмима других високошколских установа,

- да су резултати коректно наведени и

- да нисам кршио/ла ауторска права и користио интелектуалну својину других лица.

Потпис докторанда

У Београду, 11.06 .2012$.

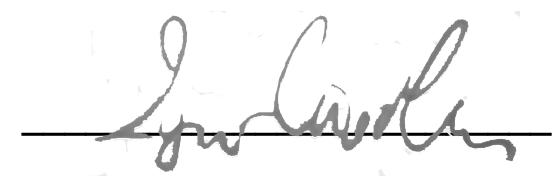


Прилог 2.

\section{Изјава о истоветности штампане и електронске верзије докторског рада}

Име и презиме аутора __ Душко Спасовски

Број уписа

Студијски програм

Ортопедија

Наслов рада Биомеханичка анализа троструке остеотомије карлице

Ментор — Проф. др Зоран Вукашиновић

Потписани __ Душко Спасовски

изјављујем да је штампана верзија мог докторског рада истоветна електронској верзији коју сам предао/ла за објављивање на порталу Дигиталног репозиторијума Универзитета у Београду.

Дозвољавам да се објаве моји лични подаци везани за добијање академског звања доктора наука, као што су име и презиме, година и место рођења и датум одбране рада.

Ови лични подаци могу се објавити на мрежним страницама дигиталне библиотеке, у електронском каталогу и у публикацијама Универзитета у Београду.

Потпис докторанда

У Београду, 11.06 .2012$.

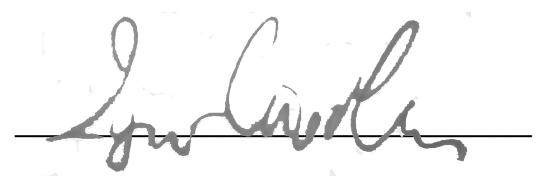




\section{Прилог 3.}

\section{Изјава о коришћењу}

Овлашћујем Универзитетску библиотеку „Светозар Марковић“ да у Дигитални репозиторијум Универзитета у Београду унесе моју докторску дисертацију под насловом:

Биомеханичка анализа троструке остеотомије карлице

која је моје ауторско дело.

Дисертацију са свим прилозима предао/ла сам у електронском фрормату погодном за трајно архивирање.

Моју докторску дисертацију похрањену у Дигитални репозиторијум Универзитета у Београду могу да користе сви који поштују одредбе садржане у одабраном типу лиценце Креативне заједнице (Creative Commons) за коју сам се одлучио/ла.

\section{1. Ауторство}

2. Ауторство - некомерцијално

3. Ауторство - некомерцијално - без прераде

4. Ауторство - некомерцијално - делити под истим условима

5. Ауторство - без прераде

6. Ауторство - делити под истим условима

(Молимо да заокружите само једну од шест понуђених лиценци, кратак опис лиценци дат је на полеђини листа).

У Београду, 11.06 .2012$.

Потпис докторанда

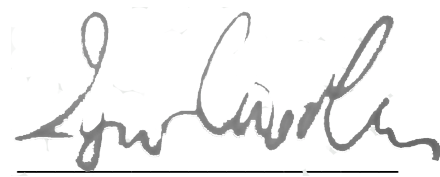

